Portland State University

PDXScholar

$1-1-1980$

\title{
An impact evaluation of home improvement loans on neighborhood decline: the case of Portland, Oregon
}

Geri Larkin

Portland State University

Follow this and additional works at: https://pdxscholar.library.pdx.edu/open_access_etds Let us know how access to this document benefits you.

\section{Recommended Citation}

Larkin, Geri, "An impact evaluation of home improvement loans on neighborhood decline: the case of Portland, Oregon" (1980). Dissertations and Theses. Paper 521.

https://doi.org/10.15760/etd.521

This Dissertation is brought to you for free and open access. It has been accepted for inclusion in Dissertations and Theses by an authorized administrator of PDXScholar. Please contact us if we can make this document more accessible: pdxscholar@pdx.edu. 
AN IMPACT EVALUATION OF HOME IMPROVEMENT LOANS ON NEIGHBORHOOD DECLINE: THE CASE OF

PORTLAND, OREGON

by

GERALDINE ANN ZARKIN

A thesis submitted in partial fulfillment of the requirements for the degree of

DOCTOR OF PHILOSOPHY

in

URBAN STUDIES

Portland State University

1980 
AN ABSTRACT OF THE THESIS OF Seraldine Ann Larkin for the Doctor of Fhilosophy presented May 30, 1980.

Title: An Impact Evaluation of Home Improvement Loans on Neighborhood Decline: The Case of Portland, Oreson.

APPROVED BY MEMBERS OF THE THESIS COMMITTEE\&
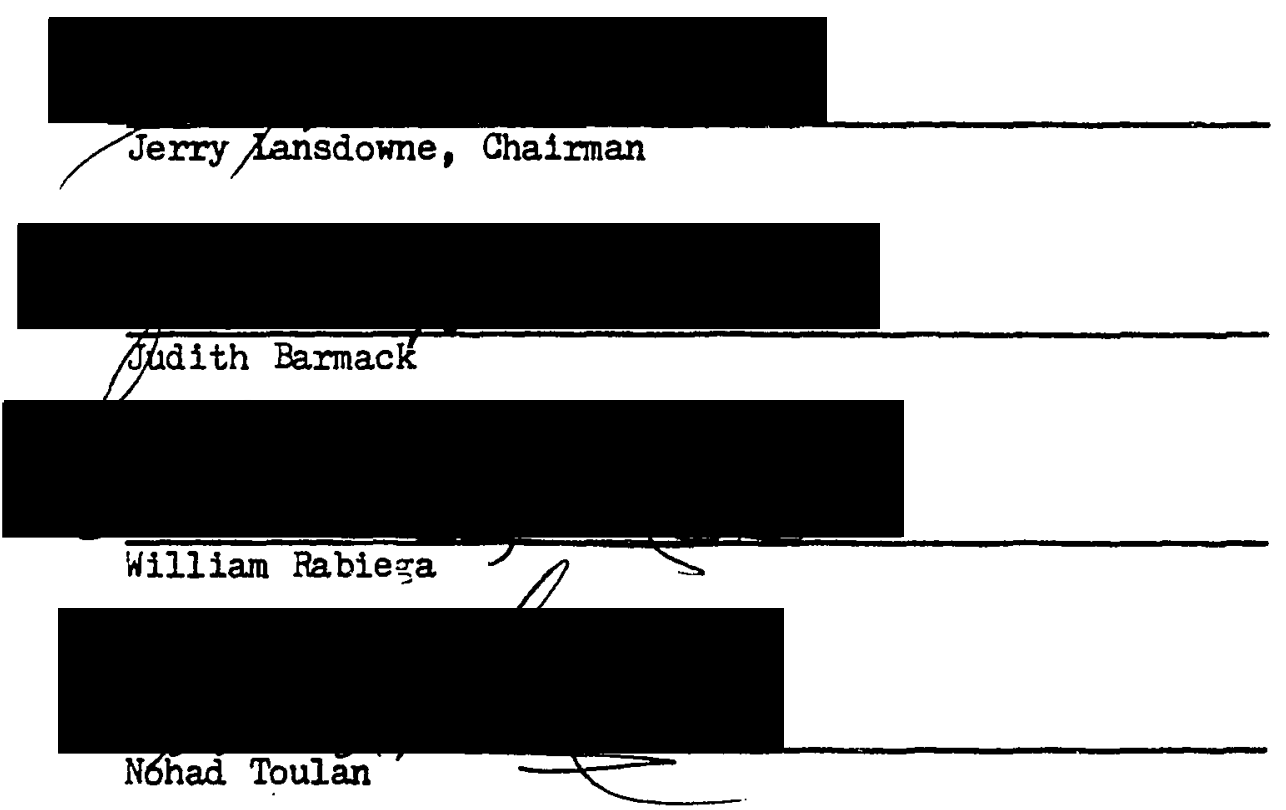

Recently federal policy aimed at halting decline in urban neighborhoods has included a major focus on housing rehabilitation efforts. In the case of Portland, Orezon, federally funded improvement loans for owner-occupied housing units resulted in the rehabilitation of almost four thousand homes from 1975 until 1978, over twice the number of homes rehabilitated in any other city in the nation. The purpose of the present study was to examine and analyze the city's rehabilitation loan program in two ways. First, the loan 
process itself was examined to ascertain whether there were any deficiencies in the loan program which should be corrected. The second, and primary, focal point was the specific neizhborhoods where rehabilitation loans have been funneled. The impact of the loan pro-rams on the nei-hborhoods as communicated by their residents determined how successful Portland has been in dealing with urban decline through its loan prograns.

Prior to rathering primary data on the nelyhborhoods, several secondary sources of information were used. The Portland Development Commission's in-house evaluations of the loan process demonstrated strong recipient support for the prorram. A survey of loan recipient files showed loans ฐoin Although half the loans went to married couples, a substantial number of loans went to divorced women and widows. The majority of rehabilitated homes were over fifty years old, and their median assessed value was $\$ 16,500$. Secondary data was also used to look at outside perceptions of changes taking place in loan relghborhoods. Real estate trends and mortrage and home improvement loan activities sugzested that the impact of the government loan pro:rans has not yet been substantial enough to trigger chanzes in private policles related to the neighborhoods. Primary data for the study came from a random sample survey of four hundred persons in four Portland nei:hborhoods. Two neirhborhoods, one in the north section of the city and one in southeast, where loans have been given, were paired with two control nelghborhoods where loans were not available. The survey instrument used contained 72 variables chosen as capable of determining what the impact of the loan program has been on loan recipients, their neighbors, and their neighborhoods. 
Four outcomes could have stemmed from the loan programs. The first possibility was that people living in the neighborhoods where Housing and Community Development loans have been granted should feel more positive about their nelshborhood than those not living in HCD nei:jhborhoods. A second consequence could have been that HCD neishborhoods are upgrading socio-economically. Third, HCD neighborhood residents sinply may not have perceived improvenents in their neighborhoods, or fourth, even if they perceive improvements, they do not show significantly hi-her levels of satisfaction with their neighborhoods than holds true for respondents living in the control neighborhoods. The data indicated that although residents in HCD nel,jhborhoods do perceive improvements taking place in their neishborhoods, their levels of satisfaction with their neighborhoods are not significantly hirher than satisfaction levels in non-loan ne1zhborhoods. Socioeconomic changes may be takin $\vec{j}$ place in the Southeast HCD neishborhood. As for the loan process, the program was rated highly by the reciplents of the loans, both in in-house evaluations done for the Portland Developnent Commission and as reported in the neighborhood survey.

The study concludes that the city's efforts provided a solid first step in developing a strong commitment to strengthening inner city neighborhoods, but it is only a first step. A stronger commitment, particularly on the part of private industry, is needed to end urban neighborhood decline. 
TO THE OFFICE OF GRADUATE STUDIES AND RESEARCH:

The members of the Committee approve the thesis of Geraldine Ann Larkin presented May 30, 1980.

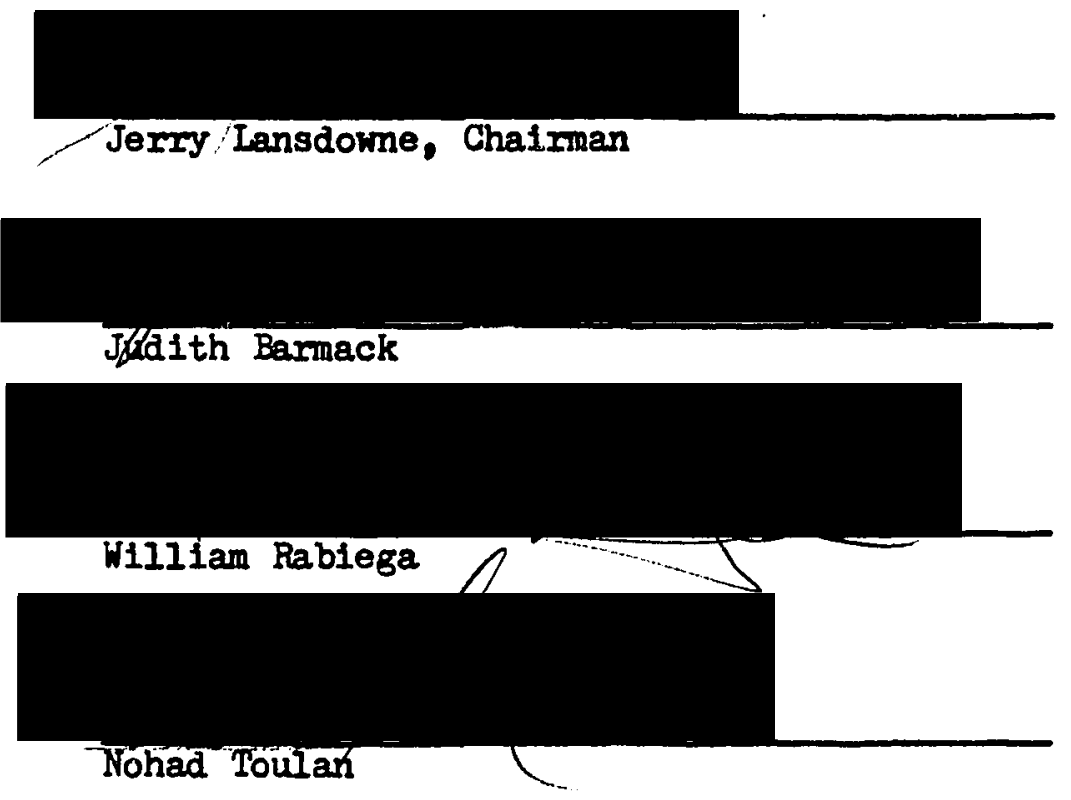

APPROVED:
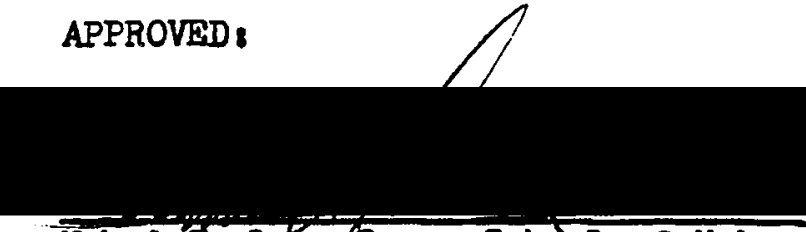

Nohad Ioulan, Dean, Schobl of Urban Affairs

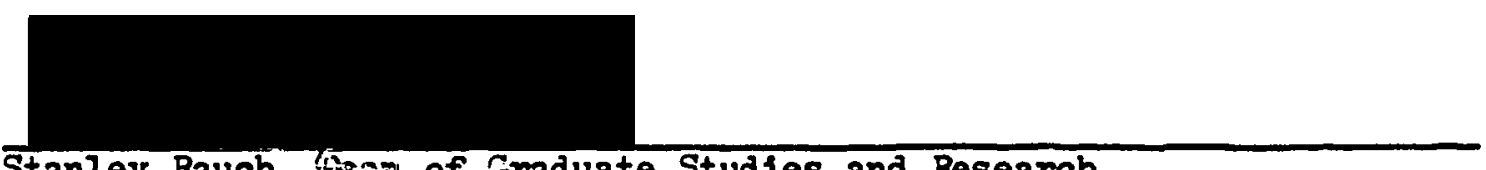

Stanley Rauch, Sean of Graduate Studies and Research 
FOR SARTH 
TABLE OF CONTENTS

PAGE

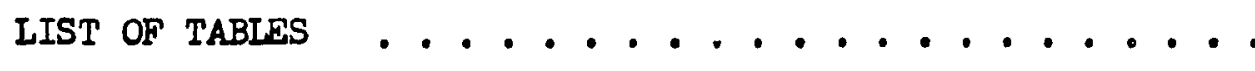

\section{CHAPTER}

I INTRODUCTION . . . . . . . . . . . 1

Context ... . . . . . . . . . 3

Evaluating the Ioan Proøran ......... 4

Program Possibilities: Who Benefits

Program Possibilities, The Neizhborhoods

Study Format ........... . 8

II BACK:ROUND, UREAN DECLINE AND FEDERAL POLICIES • 9

The Nature of the Problem ........ 9

Federal Policy .......... 13

III DEVELOPIN; CRITERIA FOR EVALUATIN; PROCESS AND PROCRAM IMPACT: THE HOUSIN; AND COMMUNITY DEVELOPNENT ACT OF $1974 \ldots 27$

Criteria for Evaluation ........ . 29

The Housing and Community Development Act of 1974 ............. 32

IV PORTLAND'S LOAN PROGRAM . . . . . . . . 37

The Portland Development Commission . . . 52

The Ioan Process ......... . . . 54 


THO

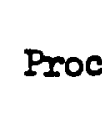

VIII IMPACT EVALUATION, CRITERIA\& OUTSIDE PERCEPTIONS

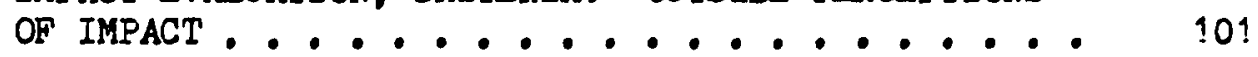

Methodolory Notes ........... 102

Market Values .............. 103

Financial Institutions .......... 106 
IX IMPACT EVALUATION, CRITERIA, SATISFACTION

LEVEIS I

Introduction $\ldots \ldots \ldots$

Findings . . . . . . . . . . . . . .

Nelarhborhood Attitudes

Neighborhood Chanzes

Specific Neighborhood Improvements

Willintiness to Stay

Public Services Ratings ...........

Public Improvements

Specific Improvements

Improvements Needed

Chapter Summary .............

$X$ IMPACT EVAIUATION, CRITERIAI SATISFACTION

IEVEIS II . . . . . . . . . . . . . .

Introduction .............. 124

Housing Conditions . . . . . . . . . 124

Age of Housin:;

Crowding

Satisfaction with House

Specific Housin Characteristics

Housing Improvements

Types of Improvements

Neirhborhood Effects

Satisfaction Levels \& Neishbors . . . .

Neirabor Rating

New People

Chapter Summary . . . . . . . . .

XI IMPACT EVALUATION, CRITERIA, NEI;HBORHOOD DIFFERENCES

Introduction ................

Income Levels

Age

Marital Status 


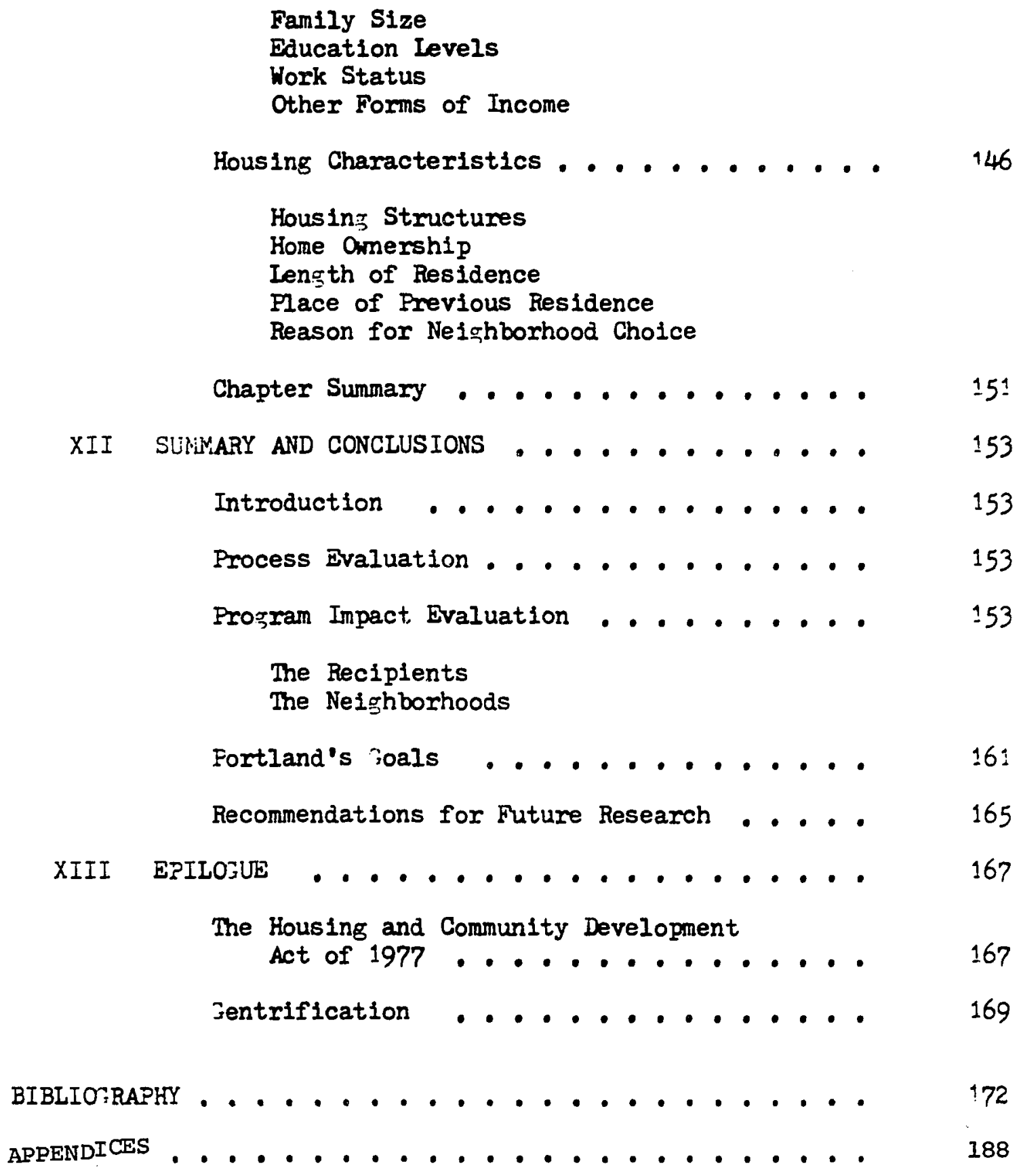




\section{LIST OF TABLES}

TABLE

PAGE

I Breakdown of Iross Project Cost of Federally

Aided Urban Renewal Programs as of

December 31, 1962 ............

II Nine Factors Affecting Delivery of HCD Capital

Improvement and Rehabilitation Assistance

Programs ..................

44

III A Comparison of Factors Affecting Delivery of HCD

Capital Improvements and Rehabilitation

Assistance Prorrams: Portland, St. Johns,

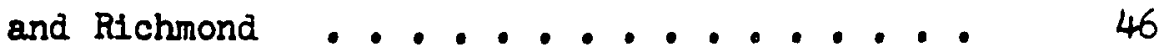

IV Housing Assistance Prozrams, Portland, Orezon . . 50

V Program Funding Sources .......... 51

vI Single-Family Home Rehabilitation Ioans,

Portland, Oregon ............

VII Irowth of Housing Rehabilitation Program,

Portland, Oregon .......... 56

VIII Income Iimits: Rehabilitation Ioan Programs . . . 58

IX Percentage of Fundinj for Specific HCD Activities,

Portland, Oregon ............

X Socio-Denomic Characteristics of Comparison

Neighborhoods, 1970 .......... . 74

XI Housing Characteristics of Comparison Neizhbor-

hoods, 1970 ... . . . . . . . . . 
XII Indicators of Urban Decline or Stability .... . 78

XIII Marital Status of Ioan Recipients ....... 87

XIV Ioan Recipient Ages ............ 88

XV Comparison of Loan Recipient Ages, Male and

Female ........... 88

XVI Ioan Amount by Race ............ 89

XVII Ioan Recipient Occupations ......... 90

XVIII Ioan Recipient Income Per Month . . . . . 90

XIX Monthly Income by Sex . . . . . . . . 91

XX Ioan Recipient Savings ........... 91

XXI Mortgare and Utility Costs I Loan Recipients . . 92

XXII Assessed Values: Recipient Homes . . . . . 93

XXIII Housing Price Trends, North, Southeast, West

Side, and Portland Metropolitan Area.... 104

XXIV Averare Market Price, Study Neizhborhoods .... 105

XXV Assessed Values and Asking Prices, Study

Neizhborhoods . . . . . . . . 105

XXVI Home Mortgase Activity Summary, Study

Neijhborhoods . . . . . . . . . 108

XXVII Home Improvement Loan Activity Summary, Study

Neighborhoods . . . . . . . . . 109

XXVIII Home Morṭ̣are Loan Activity Summary, Portland

SMSA ...................... 110

XXIX Satisfaction Levels with Public Services, Study

Neighborhoods . . . . . . . . . . 
XXX Improvements Needed Top Three Sugrestions, Study Ne1-hborhoods .. . . . . . . . . .

XXXI Housing Characteristics, St. Johns and Portsmouth ............. 129

XXXII Housin; Characteristics, Richmond and Creston . . . 129

XXXIII Most Frequent Home Improvements, Study

Neirjhborhoods ..............

XXXIV Resident Reaction to Home Improvements by Ne1rhbors . . . . . . . . . . . . .

XXXV Type of New Resident, Study Nelghborhoods . . . .

XXXVI Those Noticing Nel-hhbors' Work Efforts, Study Neighborhoods .......... 137

XYXVII Income Levels, Study Neighborhoods . . . . . 139

XXXVIII Respondent Ages, North Portland ......... 140

XXXIX Respondent ATes, Southeast Fortland ....... 14 !

XI Homeownership Patterns, Study Neighborhoods . . . 147

XII Summary of Survey Findings, Neirhborhood Survey . . 159

XIII Neighborhood Related Urban Policies . . . . . 168 


\section{LIST OF FIJURES}

FIGURE

PATE

1. Housing and Community Development Areas: City

$$
\text { of Portland, Oregon ............ }
$$

2. Iocal jovermment Structure, Portland, Oreæon .... 53

3. Map of Study Neirhborhoods .......... 69

4. Boundary Mapı St. Johns (HCD) ......... 70

5. Boundary Map Portsmouth ........... 7 !

6. Boundary Map Richmond (HCD) ......... 72

7. Boundary Nap Creston ........... 73 


\section{CHAPTER I}

\section{INTRODUCTION}

Neighborhood deterioration has increasingly been the focus of public policies almed at saving urban areas. As policymakers have come to recognize the close relationship between neighborhood decay and urban decline generally, neighborhood stability has been viewed as pivotal in attempting to ensure a healthy metropolis. As recently as November, 1978, a nationwide Gallup Poll found that a diverse cross section of federal officials, academics, and community leaders saw neighborhoodbased revitalization as the best hope for saving American cities which have been crippled over the past two decades by raclal tensions, flight to the suburbs, and declining tax bases (Christian Science Monitor Reprint, November, 1978:36). Historically, Buropean cities have shown that the pride connected with one's home and immediate environment constitutes a powerful source of positive feelings toward one's community (Whitbread, 1977). Similarly, the future of U.S, cities may well depend on the attitudes of those living in them, since residents' evaluations of their own neighborhoods as places to live undoubtedly influence their confidence in their city's future. With increased confidence can come a healthier economic base, increased tax revenues, and better services. In 1974, the federal government gave heavy priority to programs directed at stabilizing neighborhoods facing decline. The Housing and Community Development Act of that year was heralded as a comprehensive 
approach to the problem of urban decay. Community development block grants were funneled to cities which would, in turn, develop and implement policies providing for suitable housing and expanded economic activities primarily in urban neighborhoods.

In response to such directives, the city of Portland, Oregon developed goals aimed directly at the rehabilitation of inner city residential areas. Iike many American cities, Portland has experienced a growing shortage of housing since World War II, both in the downtown area and in surrounding urben neighborhoods. The loss of housing due to redevelopment efforts and neglect have made this condition particularly acute. In excess of $70 \%$ of the city's housing is over 35 years old, and 1t is estimated that some $15 \%$, or 27,000 units, did not meet minimum housing codes in 1970. Such statistics coupled with estimates of high costs of new construction led the city to focus on rehabliltation as the key to achieving a suitable living environment in the metropolitan area. The neighborhood unit was central to Portland's basic rehabilitation policy. In 1975, Portland's Office of Flanning and Development released a Community Development Block Grant proposal specifying the selection of "a few nelghborhoods each year which could demonstrate the possibility of stabilizing population and housing trends" (Community Development Block Grant Plan, 197585). The Portland Development Commission was charged with implementing four subsidized homeowner loan programs which were instituted as a means of financing the rehabilitation work. Deferred Payment Loans, or DPLs, were aimed especially at lowincome households. To be eligible, a family of four could not have a household income in excess of $\$ 7,688$ in 1976 . The loans did not have to 
be repaid until the home was sold or transferred to a new owner. The purpose of the DPIs was to provide interest-free finansing for meeting locsl housing code requirements. Locally funded HCD-3 and federally funded 312 loans were also intended to bring property into compliance with the city codes. In conirast to the DPL, these two loan types charged an interest rate of up to $7 \frac{1}{2} \%$ and had to be repaid within a twenty-year period. A fourth loan, the Fublic Interest Lender loan, could also be used for refinancing. PIL loans carried a $6 \frac{1}{2} \%$ interest rate and were to be paid within 20 years.

The first loans were awarded in the fall of 1975 and in the initial three years as dispensor, the Development Commission processed over 3500 loans worth $\$ 14.5$ million in 14 neighborhoods. Additional multi-family rehabilitation efforts brought the dollar figure to over $\$ 22$ million. A recent federal survey of nearly 1,500 cities showed that Portland was able to rehabilitate twice as many units with half the funding as the second best city in the survey (Portland Development Commission, 1978.1).

CONTEXT

The purpose of this study is to evaluate Portland's Housing and Community Developrent rehabilitation loan programs in two ways. The first type of evaluation is process evaluation. Process evaluation looks at the workings of the program itself, Does it mun smoothly? Are there any gaps in the program set-up? Are the program recipients pleased with the program?

The second type of evaluation, and the one central to this study, is program evaluation. Here the goals of the program are compared with 
program outcomes. Although targeting federal funds to localities which show high levels of need as measured by indicators of physical and social distress is important, it does not guarantee that such assistance actually alleviates the physical distress identified or necessarily benefits low or moderate income people (Keating and Legates, 1978,703). This study is aimed at assessing the impact of Portland's loan program on loan recipients, their neighboxhoods, and their neighbors to find whether physical distress in the neighborhoods as defined by the Portland Development Commission has been alleviated and to discover whether the programs have indeed benefited Iow and moderate income familles.

EVALUATING THE IOAN PROGRAM

Process Possibilities

The success of any rehabilitation program rests on two major factors. The first is process, the second impact. For Portland, the rehabilitation loan process, as described in Chapter IV, was one which combined elements from earlier rehabilitation programs undertaken here and elsewhere with several entirely new elements, such as the manner in which neighborhoods were selected for the Housing and Comnunity Development program. Before the impact of the loan programs could be evaluated, the process itself needed to be studied for its comprehensiveness and for recipient response. In terms of comprehensiveness, several questions needed to be addressed. Were areas where rehabilitation was to take place carefully selected? Vere affected residents prepared? Has financing and other forms of assistance such as counseling available? Looking at loan reciplent evaluations of the process, several 
possibilities existed. The loan process could have had internal problems such that people would be unwilling to recommend the program to others. Their unwillingness would suggest that the process as it existed was defective. Or the process could have isolated internal problems, but not enough to warrant a negative response by loan recipients when asked whether they would recommend the program. There might not have been any problems with the loan process as suggested by recipients reporting that they would highly recommend the progran.

\section{Program Possibilities: tho Benefits}

Two types of possible progran outcones were evaluated in this study. As suggested above, the first revolved around the issue of "who benefits?" The second is nore attitudinal and related to resident perceptions of neighborhood change that resulted from the loan programs. Defining the socio-economic characteristics of the recipient population helped to isolate the types of families living in Portland benefitting from the program as well as the kinds of homes in which they Iived. Were recipients IoW and moderate income as defined by the Housing and Community Development Act of 1974? Were their families laxge or small? Were they employed, unemployed, retired? Were they young professlonals just starting out on their careers or were they "blue collar" families facing the same income and job situation indefinitely? Were their homes in serfous need of repalr or were minor repairs needed? Were they older homes? These are the types of questions which were addressed and are reported in Chapter VII. 
Program Possibilities: The Neighborhoods

The central question of this study was how the loan programs have affected the neighborhoods themselves. Moro specifically, the central 1ssue was whether or not people's attitudes have changed toward their neighborhoods as a consequence of Portland's loan programs. Any observed improvements in people's feelings about their neighborhoods would suggest that the loan prograns have attained the community developnent goal of protecting those neighborhoods from decline

"because a resident's attitude about his neighborhood is at least as important as the physical quality of that neighborhood, and because his attitudes must be positive if he is to invest his resources--time and money--in that neighborhood." (Conmunity Development Block Grant Plan, 1975:5)

To provlde a framework for testing the impact of the city's loan programs on the recipients and their neighborhoods, several hypothetical situations were considered which could have developed as a consequence of such govermmental activities. The first possibility was that people feel better about their neighborhoods as a consequence of the loan activities and are therefore more willing to remain where they are, enhancing nelghborhood stability. A number of studies have isolated neighborhood conditions as being a most inportant factor in determining how poople feel about where they live (Michelson, 1966:355-360; Peterson, 1967:19-33, Butt1mer, 1972:299-318). Persons living in a substandard inneroc1ty neighborhood where a substantial number of improvements are taking place should feel more positively about their neighborhood. They should percelve that others are willing to invest in the neighborhood, ensuring a healthy future (Lansing et al., 1971,145). In this situation, people living in HCD neighborhoods will rate the quality of 
their neighborhoods more highly than those living in non-HCD neighborhoods.

In addition to the positive feelings towards one's community that came with home owmership alone, the pride connected with one's home constitutes a powerful source of positive feelings towards one's community. It can ward off the ill-effects of age, social class, crowding, and other environmental changes that come with modemization (Whitbreac, 1977 149). The pride stemming from the accomplishment of HCD-funded home improvements should lead to a stronger identity with, and concern for, the homeowner's neighborhood. Further, even if a person in the HCD neighborhood has not applied for or been granted an HCD loan, the accomplishment of others' home improvements should lead to perceptions of a more satisfactory environment.

OUTCOME POSSIBIIITY I:

If a person lives in a neighborhood where HCD loans have been granted, then his/her perceptions of the quality of his/her surroundings, 1,e. home and neighborhood, will be more positive than those of a person not living in an HCD neighborhood.

A second consequence might be that HCD neighborhoods have been upgraded socio-economically. That is, people having a significantly higher socio-economically status in terms of income, occupation, and education level may have moved into the HCD neighborhoods as a result of HCD-related improvements. Higher prices for suburban homes and rising energy costs mean that inner-city neighborhoods which show signs of upgradinæ offer increasingly appealing living environments.

OUTCONE POSSIBILITY II, Nelehborhoods where HCD loans have been granted experience in-migration of higher socio-economic status households.

It is possible that people do not perceive improvements taking place in 
their neighborhoods.

OUTCONE POSSIBIIITY III

HCD neighborhood occupants do not perceive

changes in their neigriborhoods.

Or, even when they have noticed changes, they do not show significantly

nigher satisfaction levels with their neighborhoods.

OUTCOME POSSIBILITY IV,

HCD neighborhood occupants, perceiving

changes in their neighborhoods, do not

feel better about their neighborhoods

than non-HCD neighborhood residents.

Finally, Outcome Possibility II, socio-economic changes, could have occurred with any of the other outcones.

\section{STUDY FORMAT}

The next two chapters provide a backdrop against which Portland's rehabliltation loan program can be evaluated. The . rst traces the responses tried by the federal government to combat urban decay. It demonstrates that the use of rehabilitation as a policy tool grew as other types of policies falled to deal with urban neighborhood decline. Chapter III outlines lessons learned from earlier rehabilitation efforts and offers criteria which can be used for evaluating the progran Portland developed for confronting neighborhood decay.

Although the discussion of earlier rehabilitation project evaluations and the historic context are necessary for broadly defining the progress of nelghborhood rehabilitation policies, only a specific discussion of Portland's program can offer the detalled backdrop needed for understanding the conclusions derived from this plece of research. Chapter IV describes Portland's translation of the goals and objectives of the Housing and Community Development Act of 1974 into a local policy 
of neighborhood rehabilitation spearheaded by the Portland Development Commission. The five components of the clty's policy, her objectives, goals, IIne of action, intent, and implementation of that intent are all examined. From there, Chapter V describes the methodology used for this plece of research. That chapter is followed by several chapters which report research findings regarding Portland's loan process anà program outcomes. Finally, Chapter XII offers a summary and conclusions derived from this plece of research. 
MHAPIER II

\section{BACKGROUND, URBAN DECLINE AND FHDERAI POLICIES}

Neitber a process nor an impact evaluation of any progran is possible without a clear understanding of the problem that program is addressing. Because the present national goal of urban rehabilitation revolves around the issue of urban nelghborhood decline, this chapter first provides a discussion of the dimensions of neighborhood decay. From there, federal policies ained at urban deterioration are discussed. The emphasis on the part of the national and local governments on a rehabilitation approach to decay cane out of several earlier approaches to urban decline undertaken by the federal govemnent since the $1930^{\prime} \mathrm{s}$. This chapter traces those policies to demonstrate the manner in which rehabilitation cane to be upheld as the primary policy tool to be used in the $1970^{\circ} \mathrm{s}$. The failings of earlier policles led to an effort on the part of Congress to incorporate lessons learned from those prograns into a "clean" focus on urban rehabilitation in the Housing and Connunity Developnent Act of 1974, a focus which offers criteria against which Portland's program of neighborhood rehabilitation can be evaluated, both in its impact on the neighborhoods and as regards to 1 ts process.

\section{THE NATURE OF THE PROBIEM}

With the advent of the Housing sct of 1949. Congress established the Boal of provlding all Americans with decent housing in "decent surroundIngs of their own choosing, at rents or prices they could afford" 
(Hartman, 1975:1). The substandard housing that still exists means that we have not achieved those ends as a nation. However, the problen of nelghborhood decline is more complicated than just poor housing. Local governments are involved through service delivery, investment, zoning, and taxation decisions. Financial institutions play a part through the ir willingness or reluctance to supply credit. Realtors, investors, appraisers, businessmen, and homeomers exert a significant influence through their decisions to invest in particular districts.

Actual neighborhood decline is the result of many variables, perhaps best understood in IIght of the dynamics of the housing narket. Hithin any given market, neighborhoods may be thought of as being in competition for residents. Changes in one location may directly or Indirectly affect the demand for housing in other areas. Neighborhoods decline because they lose their competitive odge, passing through a serles of stages from health to stagnation (Jacob, 1961; Greer, 1965). This decline is in itself a many-sided phenomenon. Iocal properties physically deteriorate by reason of age, Inadequate maintenance, and misuse. Clearly declining nelghborthoods can oftentimes be spotted by structures with obvious physical deficlencies, some are deteriorated, others show signs of neglect. Conmunity facilities and street patterns become obsolescent due to changing patterns of living related to shopping and transportation. For example, the sinultaneous developaent of shopping centers, increased access fron the suburbs to downtow, and relocation of jobs out of the central business district that occurred after Horld War II negatively influenced demand for housing in older innerelty nelghborhoods.

Nelghborhood erosion has social features as well. Deteriorating 
neighborhoods experience accelerated innigration of lower income, less educated families and the exodus of higher income, better educated fanliles, with a corresponding lowering of general community tone and sorale. Changing age characteristics indicate invasions of young. family-raising groups and the ovacuation of older households, placing Increasing stress on neighborhood infrastructure as well as on the area's housing stock (Hartman, 1975:2). Often erosion is race related. The growth of non-white demands for housing in traditionally all white neighborhoods has been documented as triggering perlods of transition in those nelzhborhoods characterlzed by hostility, violence, and panic sales (DiDonenico, Anita, 1978,12).

Buildings in declining areas tend to be overcrowded, as it takes more low-income persons to pay for the upkeep of the same housing abandoned by higher income groups. More properties are purchased by absentee landlords who can increase their profits by converting homes to nultifamily use, consequently, maintenance costs rise sharply with all nelghborhood owners fearing for their investnents (Denvex. Office of Policy Analysis, 1977). Increases in crimes against persons and property correlate highly with neighborhood deterioration (Jacobs, 1961). Decay has political attributes. Neighborhoods in transition tend to be inhabited by people with little political clout, leading to neglect by public agencies. As a consequence, such areas usually experience a breakdown in the enforcement of bullding codes and zoning laws. Fublic service delivery becomes inadequate relative to the needs of the incoming population (Downs, 1970).

Urban decline is intimately Iinked to the avallabllity of Institutional mortgage credit. Investments decline in the neighborhood as decay 
increases. The housing market deteriorates to the point where the areas find themselves boycotted by the normal sources of monies for purchasing and repairling residential structures. High-interest short-tern loans become the most common source of financing for the low-income families moving into the neighborhoods, adding to the erosion.

once begun, the decay process tends to accelerate and reinforce 1tself. Without financial investment, neighborhoods are left facing physical deterioration. Support service prograns tend to be social services such as welfare rather than physical, or economic (Baront and Kollies, 1978:16). Existing housing units continue to deteriorate with little rehabilitation or development of new housing. Political and social forces push the neighborhood further down the ladder (Keyes, 1969:25). In the last stage of decline, buildings are severely dilapidated and many are abandoned--demolitions have left littered vacant lots. Ifife in what is left of the neighborhood is characterized by fut1lity, fear, and apathy (M.I.T., 1979:13). Helting the process before that last stage is reached becomes a formidable task.

\section{FEDERAL POLICY}

As a nation we have tried many different kinds of prograns to protect urban neighborhoods from decline, to stem any decay which has already taken place, and to redevelop decayed areas. From the first, planners have belleved strongly in the reforming qualities of improved neighborhoods. In the words of Ie Corbusier, the noted architect, "Reform the conditions of habitation and you can eventually improve man's behavior" (HeIcher, 1976:181). 
Although most "housing" pollcies of the tiae focused on salvaging lending institutions, the onslaught of the Depression made it apparent to some government officials that without substantial outside help many Americans could not afford adequate housing in a decent environment. For those officials, the initial impetus for aid was largely humanitarian and based on the widely held observation that families with inadequate housing, in substandard neighborhoods, were often prey to problems of poverty, crime, and bad health. A national housing policy was regarded as a useful, if partial, solution for the problems of both poor housing and urban decay (Saffran, 1976,234-235). It was thought that govermment intervention could overcome the faulty workings of the private market. Catherine Bauer, as one official concerned with housing, expressed this feeling in her testimony before the Senate Committee on Education and Labor, June 4, 1935 :

Part of the housing problem is a simple economic fact, Ordinarily private enterprise is totally unable to provide adequate nok housing at a rental or sales price which families in middle or lower income groups can pay. This situation is apparently permanent in our national economy (Semer et. al., 1976:115).

Further impetus for intervention stemmed from the desire to rescue downtown business areas from economic and physical decay (Saffran, 1976. 234-235).

Prior to the Housing and Community Development Act of 1974, rehabilitation efforts played a minor role in the many government approaches to urban improvement. Because no govermment agency had authority to undertake slum clearance, let alone rehabilitate buildings, low-interest mortgages and construction subsidies provided much of the focus for the National Industrial Recovery Act of 1933 (Semer et. al., 1976,84-87). 
The National Housing sct of 1934 contalned a Title I guarantee which specifically assured payment of loans made for the purpose of home improvement (Curtis et. 8l., 1969:751). The major thrust of the Ast, however, and of those which followed closely thereafter, was to refinance homes that were lost due to the Depression. Under the Act, the Home Orners Ioan Corporation made loans to save the homes of millions of families whose mortgages had been foreclosed. It should be noted that as a byproduct of this activity, HOLC did make some loans for the repair, modernization, and improvement of residential properties, though those numbers are not signiflcant (MeFarland, 196584). The insurance schemes guaranteeing mortgages and rehabilitation loans went to people through private agencies. In so doing, they supported the preference of private lenders for new houses, for single family houses, for younger families, and for white fanilies. That left out most inner city nelghborhoods faced with decay (Greer, 1965:134).

The Housing Act of 1937 provided some additional funding for Titie I. In addition, the Act directed attention toward the development of public housing and slun clearance, a theme which was elaborated by the Housing Act of 1949.

With the Housing Act of 1949, the government established a national goal of a decent home and suitable living environment for all Americans. To achieve that goal, a program of urban redevelopment or urban renewal was inftiated. Whatever the goals on paper, from the outset urban renewal by-passed the issue of providing for decent housing in Iivable surroundings for all Americans. The programs implemented under urban renewal were middle-class in orientation and geared to helping downtown businesses more than anything else. Prograns established by the Act allowed a Local 
Public Agency (IPA) to take privately owned urban land by the right of eminent domain, clear it of structures, and sell it to private developexs for the construction of new residential buildings. Such development was aimed at providing more and better housing through the spot removal of residential slums. Yet there was no necessary link in the redevelopment program between the original downtown dwellings and the units that went up in their places. For the most part, low-cost housing was replaced with middle class housing or office space (Keyes, 1969.3).

Urban renewal did not save existing urban neighborhoods or prevent decay (Anderson, 1964; Greer, 1965; Wilson, 1966). Further, in a study of urban renewal in Boston's West End, Herbert Gans concluded that severe unanticipated social costs were imposed as a result of the so-called redevelopment of that comnunity. Ironically, the reduction in social costs associated with the removal of "slums" had been one of the primary justifications for urban renewal.

UItimately, the bulldoring approach that came to be associated with urban renewal seemed to hurt urban areas more than it helped them. By the mid-nineteen fifties, local govermments were asking for a different way to save their communities. As Charles Abrams (1965:86) reports, by "1954 urban renewal lay in the dumps. Some 211 localities were interested but only 60 had reached the land acquisition stage.... The passage of five years with aimost nothing to show for all that fanfare was hardly progress."

In response to acknokledged deficlencies in the $1949 \mathrm{Act}$, amendments were offered in 1954 which transformed the program from one aimed at bulldozing residential slums to one concerned with conserving the existing stock of housing. And since substandard houses tend to cluster by area, 
substandard areas became the focus of conservation efforts. Rehabilitation started to enter the lexicon of federal agents. Housing shortages, projected population growth statistics, and realistic production expectations meant that dilapliated and basically unsafe inner city dwelling untts would be the only hones available for millions of low and moderate Income families and individuals in the foreseeable future, even with urban renewal.

Following the fallures of earlier urben renewal efforts, the advantages of rehabilitation started to become apparent. Rehabilitation could save structurally sound buildings. Many venerable bulldings have certain anenities that could not be feasibly duplicated by current construction methods, such as large rooms, high cellings, hardwood trims, stained glass windows, etc. These could be saved. Rehabilitation could protect the network of physical and social infrastructure alraady developed in older neighborhoods. It could reduce the need for relocation. Since at least the shell of the bulldings remained, rehabilitation would be cheaper and faster than new construction. It could have a bandwagon effect, in that property owners adjacent to rehabilitated areas were $11 \mathrm{kely}$ to undertake improvements of their om. Finally, some felt that rehabllitation would be most appropriate for neighborhoods where conditions were declining, but where the housing itself was st1ll generally sound (Wexler and Peck, 1975830). As recently as 1967, former HUD Secretary Robert Weaver strongly supported rehabilltation efforts before the Senate Comittee on Banking and Currency when he stated that:

Through this route, decent housing can frequently be provided for one-half or less of the cost of new construction. This makes it much easier to bring acceptable housing within the means of the urban poor. Thus, residential rehabilitation is one of the best 
and quickest means of Increasing the supply of decent housing for families of low income. The substantial economic and huran costs of the fanily displacenent caused by redevelopnent and new construction are also eliminated or substantially reduced by rehabilitation. Rohabilitation is particularly appropriate for serving the housing needs of large fanilies of low income. Existing buildings susceptible to rehabilitation are often ideally suited in size and spaciousness for housing families with many children, at costs which can be brought within their means (Center for Community Change, 1978.3).

From the project planning basis of the 1949 Housing Act, to the Workable Pragran of 1954, to the General Neighborhood Renewal Plan of 1959 and into the 'sixties, the trend was to transfer the geographic scope of renewal projects from the plots of land chosen for their reuse value after clearance to total nelghborhoods in which the preservation of that area's fabric became the basic concern (Greer, 1965:25), marking an important change in the attitude of Congress toward inner city neighborhoods. A melange of prograns specifically intended for rehabilitating neighborthoods were introduced. Most focused on bringing mortgage funds into the renewal of slun housing. FHA mortgages were issued by private lenders, permitting relatively cheap, long-term credit. Direct federal loans were offered for rehabilitation. Outright grants to low-incone homeowners were aimed at helping them remodel their quarters on an individual basis. No one presumed that rehabilitation would be easy:

For maximun and assured success, action must be taken as a united conmunity enterprise, based on broad, carefully planned patterns, experienced technical guidance, Include detailed recommendations for repair, directiy or indirectly provide a financing medium easily and cheaply available to those who cannot themselves supply the funds necessary to defray the cost of such repair and reconstruction, deal with community problems such as opening and closing streets, establish recreational areas... with sympathetic and continuously energetic leadership 
(McFarland, 1965:7).

From 1954 to 1961, 155 "rehab" projects were undertaken in 117 localities, rehabilitating 97,821 drelling units. Typically, a rehabilItation project involved two and sometimes three levels or standards of improvement. At the first level, structures were inproved to meet local housing codes and ordinances. At the second level, housing was improved so that it met FHA physical standards. Finally, urban agencies often developed their own safety standards which were higher than either of the other two.

Yet the programs were hanstrung by complicated bureaucratic procedures, weakened by timid lenders and administrators and severely strained by paltry appropriations (Berger et, al., 1969.751). As an . example of complicated procedures, although projects were to be initiated at the local level, they had to be passed upon by the federal government at many points. A "planning advance" first had to be applied for so that a detailed plan could be worked out. That plan then had to be evaluated according to financial feasibility, local political commitment, and whether or not it was indeed "workable". To prove a plan was workable, local governments had to fulfill seven major requirements, including the development of adequate housing codes and ordinances, a comprehensive community plan for land use and public capltal development, neighborhood analyses to determine where blight existed, an administrative organization adequate to an all out attack on slums and bilght, a responsible program for relocation of displaced families, a citizen participation procedure for the entire program, and finally financial resources for carrying out all of the above. Such requirements meant coordinating the efforts of the local city council, varlous departments within city hall 
(code inspection and enforcenent, assessment, land use planning and zoning), as well as different levels of local government (state, municipality, county). Equally important, it required the cooperation of neighborhood residents, owners of property to be rehabilitated, and Investors in the real estate market (Greer, 196589-35).

Local program administrators tended to be timid, since most were appointed officials of local governments with no strong rights of tenure. They held their jobs by the will of a diverse set of political leaders, and taking any major steps toward rehabilitating low-income housing risked losing that political support. Moreover, though laws for maintaining and uperading housing may have been on the books in most cities for some time, the laws were difficult to use because of weaknesses in the legal structures for enforcement (Greer, 1965:36).

As for private lenders getting involved in rehabilitation, most of them viewed rehabilitation as a risky business. Even if the prospects of repayment of the loan were very high, the lending institutions would still not find it appealing because the amount of the typical loan would be so low that the profit they could make on the loan would not justify the cost of writing it (Anderson, 1964:158).

Finally, Table I offers an example of the paltry appropriations mentioned above. For a typical urban renewal project, rehabilitation accounted for less than $1 \%$ of the total appropriations. By December 1962. 225 urban renewal projects had involved some rehabilitation efforts. Where the total number of housing units in the projects numbered 148,000 , only 1\%\% had been rehabilitated (Housing and Home Finance Agency, 1962:286.). During the same period, all elements of housing costs, e.g., financing, malntenance, and property taxes, continued to rise steadily, leaving most 
housing for low and moderate income familles across the country in Intolerable condition. Garbage-strewn buildings with broken stairs and handra1ls, nonfunctioning furnaces, hazardous wiring, poor insulation, and leaky roofs were commonplace (Fhillips and Axyson, 1971 8835).

TABLE I

BREAKDOWN OF GROSS PROJECT COST OF FEDERALLY AIDED

URBAN RENEWAL PROGRAMS AS OF DECEMBER 31, 1962

\begin{tabular}{lcc} 
& $\begin{array}{c}\text { Amount (millions } \\
\text { of dollars) }\end{array}$ & Per Cent \\
\cline { 2 - 2 } & $\$ 2,966$ & 100 \\
Gross Project Cost & 1,981 & 66.8 \\
Real Estate Purchases & 304 & 10.3 \\
Site Improvements & 275 & 9.2 \\
Supporting Facilities & 110 & 3.7 \\
Interest & 83 & 2.8 \\
Site Clearance & 79 & 2.7 \\
Administration and Overhead & 49 & 1.7 \\
Survey and Flanning & 48 & 1.6 \\
Other and Miscellaneous & 16 & .5 \\
Relocation & 16 & .5 \\
Inspection & 5 & .2
\end{tabular}

Source: Urban Renewal Administration (1962). Urban Renewal Project Characteristics. Washington, D.C. p. 16.

In the years 1950-1960 alone, 2.25 million standard dwelling units became substandard and another 1.5 million substandard units were constructed (Anderson, 1964:149).

In spite of Secretary Weaver's statement reported earlier, few efforts at rehabilitation occurred in the 'sixties. Even with urban renewal, the Kennedy administration was confronted with increasing urban deterioration. In his housing message of 1961, Kennedy acknowledged the need for stronger actions on the part of the federal government, "ide must move with new vigor to conserve and rehabilitate existing residential 
districts" (McFarland, 1965:102). The Housing Act passed during his tenure reaffirmed the federal govermment's commitment to a broad progran of urban reneral, finally putting as much stress on rehabilitation as on clearance. Now legislative tools to make rehabilitation efforts more effective were added. FHA programs were further Iiberalized to help finance remodeling efforts. Below Market Interest Rate Ioans for rehabilitation were granted for nonprofit, limited dividend, or cooperative organizations. Yet considerable frustration was experienced among those directly concerned with rehabilitation. In most places, despite much planning, zeal, and effort, progrsss was disappointingly slow. Altogetiner, the Kennedy administration accounted for only several thousand rehabilitated units.

Considerable progress was made during the Johnson administration by comparison. Taking full advantage of the overwhelming Democratic majority in Congress, Johnson was able to win Congressional approval for a number of measures of critical inportance to the cities. The Housing Act of 1964 authorized a new IOW interest rate (3\%) direct loan program to finance rehabilitation in urban renewal areas and contained several provisions designed to encourage and assist code enforcement efforts. A revolving fund of $\$ 50$ million was authorlzed for these loans in 1964 , rising to $\$ 100$ million per year in 1965 (Weicher, 1972.9). Section 312, Introduced by the 1965 Housing Act, provided low-interest loans generally Intended for the rehabilitation of one to four unit bulldings by ormeroccupants or absentee owners of houses in urban renewal or federal code enforcement areas. Section 115, Introduced the same year, provided rehabilitation grants to families with under $\$ 3,000$ annual incone. In the face of continued slow production of rohabilitation units, the federal 
government made several attempts to help develop a large scale housing rehabilitation industry. Ten percent of all urban renewal funds (about $\$ 300$ million out of $\$ 3$ billion for f18cal year 1966 through 1969) was devoted to rehabilitation grants or loans for low income homeomers (Weicher, 1972:9). It was believed that an important advantage of large scale activity was that savings could be realized and passed on to low Income consumers of housing. Thus several major demonstration programs were undertaken in Chicago, Philadelphia, New York, and Boston (Wexler and Peck, 1975:102).

Despite such increases in federal programs, urban discontent mounted. Verbal complaints tumed into overt action as black poor violently expressed denands for a more meaningful and effective government response to the erosion of their neighborhoods. In reply, Johnson offered a "comprehensive approach" for dealing with urban decay.

One of the last acts of the Eighty-Ninth Congress was to pass the Demonstration Cities and Metropolitan Development Act in the fall of 1966. The Model Cities program, a key feature of the Act, had a central goal of saving urban neighborhoods. Although rehabilitation was stressed, the program formaliy recognized that revitalization of the physical contours of a residential district was not a sufficient mechanism for bettering the lives of all groups living in that area. So Model Citles was ained at improving the total quality of life within specific target neighborhoods by emphasizing a coordinated approach to the social and physical problems of older urban nelghborhoods. With strong backing from the White House, the Departnent of Housing ana Urban Development would channel the existing flow of federal resources from other agencles into selected poverty nelghborhoods where a great concentration of effort could 
demonstrate sigaificant results (Frieden and Kaplan, 1975:5). The program would "rebuild and restore entire sections and nelghborhoods of slun and blighted areas through the concentrated and coordinated use of all available federal aids and local private and governmental resources... necessary to improve the general welfare of the poople living or working In the areas" (U.S. Congress, House Subcomittee on Housing of the Comittee on Banking and Curroncy, $1966: 2$ ).

Model cities was a colossal fallure. The resistance of administrators, the rigidities of the programs and procedures, and the competing clains of other constituencies all interasted in varying ways to frustrate program supporters' hopes for success. Iack of support from the White House was added to thinned out approprlations of $\$ 900$ million to be spread out over 66 cities for a six-year period (The administration had requested $\$ 2.3$ billion). How particlpating cities would be given special priority was never worked out. In fact, just the opposite happened.

Your committee... .uishes to make very clear its intent that the demonstration cities program will not in any way change the flou of funds, as anong citles, under existing grant-in-aid programs. The demonstration cities program does not provide any priority in the use of existing Federal grant-inaid programs for cities which participate in the demonstration program (House Comittee on Banking and Currency, 1966:15).

Program-related 1ssues were never resolved. For exanple, it was never clear whether Model Cities was really a demonstration or national program. No one was ever slire whether its main purpose was to test innovations or to help slum dwellers catch up with the rest of soclety. It was never certain whether the program could secure the necessary federal resources without raising havoc anong other users of grant-in-aid programs. Effective coondination of existing federal programs was never 
achieved. Fear of being charged with encroachment on the turf of local governments made many federal agencles wary of offering assistance. Finally, neither the Model Cities legislation nor later HUD guidelines provided the cities or federal departpents with precise work prograns. In 1968, Congress contended that:

This (1949) goal (of a decent home in a decent nelohborhood) has not been fully realized for many of the nation's lower income families; that this is a matter of grave national concern; and that there exists in the private and public sectors of the econony the resources and capabilities necessary to the full realization of this goal (Downs, 1970:115).

That year, congressional leaders called for the further production of 26 million new and rehabilitated housing units by 1978 (Nenno, 1978:342). We have fallen far short of this goal. Some of the failure was due to President Nixon calling a moratorium on national housing programs in 1973. High costs of housing materials, land, labor, and a shortage of skilied rehabilitation Horkers also hurt production. Only 17.5 million new or rehabllitated units were finished by 1978. The biggest shortfall was where assisted housing was to be offered to low and moderate income families. Iess than half of the six million housing units prescribed for the poor were ever built (Nenno, 1978.342). The Joint Center for Urban Studies at M.I.T. and Harvard estimated in 1973 that in that year as many as 16.8 million families lived in substandard housing, most of it urban. Further, more and more households were facing substandard housing in deterlorating neighborhoods simply because the income of the household could not keep up with rising housing costs (Nenno, 1978.342-346). Regardless of the community improvement programs, minimal lasting and positive impact was made on neighboxhoods by any federal progran. 
Looking at 1974, the year the Housing and Community Development Act was finalized, housing starts had fallen to a four and a half year low. The number of new housing units in that year was 1,336,300 compared to over two million in 1973 and $2.6 \mathrm{million}$ in 1968. High interest rates were keeping all but the middle class out of the housing market, where the median price of a new single family home was $\$ 37,000$ (Congressional Quarterly, 1974:341-342).

Both President Nixon and Congress supported the concept of a new comprehensive approach to urban problems. Nixon charged that under the last "comprehensive" approach only a few low income families in a few arbitrarily selected conmunities could live in federally supported substandard housing, while most people living in decayed or decaying areas were Ignored,

The present Aministration and the Congressional Comnittees having jurisdiction in this area have also chosen to pursue a strategy that strongly favors preservation over production. Like 1973. the call has been sounded in the bureaucracy for new 1deas and methods. In the area of research, however, what was true in 1973 still prevails. There is very little that might be undertaken that critics of the Department could not describe as warmed over versions of previous approaches, , which thenselves did little to change the industry (The Department of Housing and Urban Development, 1974).

Recognizing that in 18 years, urben renewal had accounted for only 180,000 rehabilitated housing units nationwide, the Fresident called for a return of the control of the community development to the communities themselves and stepped up rehabilitation efforts. The chapter that follows outlines the response of Congress to that call. As will be seen, delegates built on lessons learned from earlier renewal policies to develop a "new" streamlined approach to neighborhood decline in the Housing and Comminity Development Act of 1974. 
CHAPTER III

DEVELOPING CRITERIA FOR EVALUATING FROCESS AND PROGRAM

IMPACT: THE HOUSING AND COMMUNITY DEVELOPMENT

ACI OF 1974

In responding to Nixon's call for a new approach to urban problems, Congress benefited from a number of evaluations of earlier rehabilitation efforts. Urban research had Identified several factors which enhance the success of rehabilitation schemes.

The Boston Urban Renewal Project, for one, has been widely studied. In that progran, 2,700 housing units were rehabilitated by five builderdeveloper teams. Structural elements were repaired and refinished, new plumbing was installed, and the homes were rewired. Although two thousand units were rehabilitated in eighteen months alone, BURP had some huge problems. Flrst, relatively expensive buildings were rehabilitated. In their eagerness to do the job quickly, contractors did not search for less expensive buildings probably in poorer structural condition. As a result, many of those assisted by the project were not those most in need, and in at least one neighborhood the program led to a decline in the amount of low cost housing available.

Langley Keyes $(197084)$ from the Joint Center for Urban Studies at Harvard, listed a number of modifications which might have made BURP more successful. Basically, he argued that neighborhood people should have been trained so that they could take part in the rehabilitation efforts. Community support was essential. He concluded that without the BURP 
process modified with the lessons leamed in Boston, "there is little hope of ever doing rehabilitation on a scale that can turn a neighborhood around."

In an earlier study for the Douglas Commission, the Boston Municipal Research Bureau examined nationwide experience with Ioan and grant programs where code enforcement was used as the primary focus of rehabilitation efforts. The Bureau found that the increase in market values yielded from the use of loan and grant funds generally did not exceed the actual costs of rehabilitation. It also concluded that the maximum grant, which was $\$ 1,500$ at the time, was not sufficient to bring homes up to code standards and that this resulted in administrators approving work that was not adequate.

As for citizen involvement, in a study of housing development corporations operating in the south end of Boston, the Housing and Community Research Group argued that efforts to activate neighborhood organizations toward rehabilitating housing often lead to high resident expectations and low performance levels. Not only did the efforts of the corporations they studied have no significant impact on neighborhood housing, but they may have deflected attention from more basic remedies like changing property tax incentives.

Paul Niebank and John Pope (1968) examined a Philadelphia rehabilitation effort, the Queens Village, Inc., housing development corporation. This group did not achieve its production goals and had difficulty selling units. The authors felt that the critical problems in that instance were the inexperience of the sponsors and contractors and a lack of special rehabilitation-construction methods.

John Kenower's report on a group of non-profit housing rehabilitators 
located in Providence, Rhode Island reached somewhat more optimistic conclusions. While the Fhode Island effort falled for the same reasons as those mentioned above, the efforts of a similar project in Springfield, Massachusetts fared considerably better. Kenower accounted for Springfield's success in terms of the neighborhood, 1.e., housing that was still structurally sound, FHA cooperation, an effective community relations policy, and sufficient subsidies (Wexler and Peck, 1975:107).

\section{CRITERIA FOR EVALUATION}

Based on these studies, a number of factors appear to be necessary to successful rehabilitation undertakings. Careful and detailed study of the social and economic feasibility of rehabilitation is essential while the project is in its planning stage and before extensive federal and local comitments are made for its execution. Such studies should cover the attitudes and characteristics of area residents and their capacity for supporting rehabilitation efforts. Detailed studies need to be made to discover the costs of the proposed rehabilitation. Are the incomes of owmers sufficient to make payments on loans needed to f'inance rehabilitation? Can they maintain rehabilitation once the rehabilitation efforts are completed? Can tenants afford rents sufficient to support a higher investment by the ormer? Explicit and reasoneble standards need to be developed and rorked out item by 1tem.

Establishing rehabilitation standards in a rundown neighborhood calls for a difficult belance between the desirable and the possible. On the one side, standards must be compatible with the type of structures and land use found in older sections of the city and low enourh so that residents can afford rehabilitation without excessive 
displacement. Yet they need to be high enough to provide decent, safe, and sanitary housing and give a reasonable promise of triggering a stable social and economic revival of the nelghborhood (McFarland, 1965:1).

Tire and time again, code enforcement has been held to be central to the success of rehabilitation efforts. Unless rehabilitation areas can get effective enforcement of building and zoning laws, not only within their boundaries but in surrounding communities as well, it is next to impossible to improve and stabilize the area. Finally, successful rehabilitation rests on the assumption that property owners can find reliable contractors prepared to do the work. Yet the private rehabilitation industry remains one of the weakest links In the rehabilitation chain. Up to the 1970 's, most American homebuilders have show little interest in residential rehabilitation. So far, little entrepreneurlal drive has been found, resulting in excessive rehabilitation costs.

So successful rehabilitation means training skilled manporer. It means strengthening the tools for neighborhood improvement, including better provision for public facilities and services, property omer counseling and assistance, and liberalized financing. Some urbanologists have argued that the powers of eminent domain need to be used to enforce rehabilitation standards. Others argue that basic changes are necessary in local, state, and federal laws to romove elexents which reinforce the profitability of neglect, substituting affirmative Inducements for property improvement. For example, tax structure changes might include tax decreases with increased upkeep of buildings of over a certain age. 
Translated into the actual implementation stage, research suggests that five major steps constitute the groundwork necessary for any successful rehabilitation process I

1. Careful selection and delineation of the area where rehabilitation is to take place.

2. Appropriate preparation of affected residents.

3. Examination of economic and social characteristics bearing on the feasibility of rehabilitation.

4. Establishment of reasonable and specific physical rehabilitation standards.

5. Provision of aeans of financing and assistance to property owners to get the work done including counseling, waxk write-ups and assistance in applying for financing.

The program's impact should be felt most strongly by low and moderate income city residents living in homes in disrepair in neighborhoods facing decline. The repair of their homes through the rehabilitation progran should help to save the physical and soctal structure of the neighborhoods, reducing the need for relocation either because of housing deterioration or because of unsupportable increases in housing costs steming from the program.

Successful rehabilitation programs can produce a bandwagon effect where one improved home leads to others improving their homes as weil. Finally, a successful neighborhood rehabilitation program should affect the att1tudes of nelghborthood residents. They should be aware of the improvement efforts taking place in their nelghborhood, 1deally leading to improvemerts in their levels of satisfaction with the neighborhood. 
THE HOUSING AND COMMUNITY DEVELOPMENT ACT OF 1974

Painfully aware of its fallures in dealing with urban decline, Congress passed a comprehensive Community Development Act on August 22, 1974, authorizing over $\$ 8.4$ billion for combating urban neirhborhood decay. The combined action of passing the Act and appropriating funds for carrying out its objectives simultaneously marked the first time that congressional leaders had shown a serlous commitment to solving the problem of housing, and neishborhood deterioration (Nathan et, al.; 1977 1219).

Called a charter for a new course in the nation's housing and urban aid prorrams, the bill substituted a community development block grant pro:jram for seven categorical urban aid programs model cities, water and sewer facilities, open spaces, neighborhood facilities, rehabilitation loans, and public facilities. Seven national objectives were central to the Act against which the success of any rehabilitation program could be measured.

1. To eliminate slums and blight.

2. To eliminate conditions detrimental to health, safety, and public welfare, through code enforcement, demolotion, interim rehabilitation assistance, and related actions.

3. Conservation and expansion of the nation's housing stock.

4. Expansion and improvement of the quantity and quality of community services.

5. More rational utilization of land and other natural resources and better arrangement of needed activity centers.

6. Reduction of isolation of income groups within communities and promotion of an increase in diversity and the vitality of neighborhoods.

7. Restoration and preservation of properties with special value for historic, architectural, or esthetic reasons. 
Maikers of the bill were particularly concerned with low and moderate income groups, 1.e., those whose grass incomes were not in excess of $50 \%$ of the median income in their communities at the time of the initial actions taken under the Act. These groups were to make up the reciplent population of the HCD programs. Where home improvement was the aim, people with up to $80 \%$ of the median income were to be included. In Portland, Oregon that translated into a gross income of $\$ 10,950$ annually for a four person household in 1975.

As suggested above, upgrading urban nelghborhoods was given heavy priority. Congressional intent reflected an $80 / 20$ breakdown in funo allocation to metropolitan and non-metropolitan areas. The Act's goal of a decent living environment for all Americans was to be accomplished through provisions for suitable housing and expanded economic activities. Increased public services were deemed important. The use of land was to be improved, and neighborhoods diversified. Buildings and areas with special properties were to be preserved. Existing housing programs were extended and reformed, and a new "Lousing Assistance Payments" program received dominant emphasis as the major vehicle for federally assisted housing. Help could be provided to individuals through direct grants and loans, or as private loan subsidies or guarantees.

Iocal governments vere given responsibility for the day to day operations of HCD. Every community was given automatic entitlement to federal assistance funds. If a local community were to reject this offer, It had to come through a deliberate decision to ignore its local housing and development needs. Housing assistance plans were to be developed from surveys of each community's housing stock and were to include evaluations of substandard housing and housing needs, as well 
as goals for the delivery of neu and rehabllitated housing. Applicatlons for community development block grant funds had to contain threeyear community developnent plans and an annual community development program as well as the housing assistance plan (Nathan et. al., 1977:220). Funds were granted for broad categories of activities including the acquisition, renewal, improvement, and disposition of real property, some code enforcement, property demolition, and historic preservation. A fairly wide range of types of housing was made eligible for rehabilitation. Single family dwellings, multi-family structures, and hotels were all eligible.

The principle methods for providing rehabilitation assistance are summarized below: (Pennsylvania Department of Community Affairs, 1978:1-3)

1. Direct grant, The locality uses community development block grant funds to make direct loans to property owners to cover the cost of rehabilitation. The property owner is not required to make repayment.

2. Direct loan: The locality uses community development block grant funds to make direct loans to property orners to cover the cost of rehabilitation. The loans usually carry a lower interest rate (0-6\%) and a longer term of repayment (7-20 years) than are available from private lenders. Ioan repayments may be used to make new loans.

3. Conditional Grant/Forgivable Loan: A conditional grant must be repaid if the property owner does not meet prespecified conditions, such as occupyins the property for a certain period of time. A forgivable loan does not need to be repald if certain conditions are met, such as property occupancy.

4. Partial loan: A partial loan is made at belowmarket interest rates by the public agency to cover part of the cost of rehabilitation. The remaining part may be covered by a variety of 
outside sources as determined by the property owmer (1.e., savings, personal loan, etc.). Its effect is to reduce the total cost of the rehabilitation work.

5. Rebate/Partial Grant, The public agency uses community development block grant funds to make direct grants to property owmers to cover part of the cost of rehabilitation. The remaining part is financed by outside sources of funds as with "partial loen", noted above. The public agency may give a rebate either before rehabilitation begins or after rehabilitation is finished.

6. Interest Subsidized Ioan: A private financial institution makes the loan to the property owner at the market interest rate to cover the full cost of rehabilitation. Community development block grant funds are used to pay a portion of the monthly payment to the lender, thereby creating a below-market loan for the borrower. The public agency usually pays the total subsidy amount at loan settlement instead of making monthly payments.

7. Prinoipal Subsidized Loan: The cost of rehabilitation is financed in part by a grant of community development block grant funds to the borrower. The property owner is required to make a monthly payment equal to the cost of the work financed at market rates.

8. Juaranteed Ioan : Community development block grant funds are placed in a private financial institution and are used to guarantee either in full or part, conventional home improvement loans made to property owners at below market interest rates. The amount of community development funds used is equal to e1ther 1) the full guaranteed anount of the outstanding principal balance of all guaranteed loans, or 2) a percentage of the guaranteed amount of the outstanaing principal balance of all guaranteed loans.

9. Compensating Balance Loan: Community development block grant funds are deposited in a private financial institution, and the institution makes improvement loans to property owners at belowmarket interest rates. The deposit account may be interest or non-interest bearing. Funds may be deposited as a lump sum or per transaction. Deposited funds guarantee loans, reduce risk, and subsidize the institution's loss in case of default. 
10. Tax-exempt Credit Agreement? Interest paid to the private financial institutions by a public egency is exempt from Federal income taxation. Funds for rehabilitation financins may be borrowed, therefore, at below-market interest rates, 1,0, about $6 \%$. This enables the public agency to make rehabilitation loans to property owners at about $6 \frac{1}{2} \%$. The public agency may assure repayment to the institution through establishnerit of a loan guarantee fund, or FHA Title I Property Improvenent Ioan. Insurance may cover each loan made (Pennsylvania Department of Community Affairs, $1978: 1-3)$.

Congress endeavored to incorporate into the 1974 Act recommendations based on evaluations of earlier housing programs and expert opinions on housing issues. To give an example, variables outside of the condition of the actual structures to be rehabilitated were to be taken into account before any work was to be done. The neighborhoods were to be free from serious adverse environmental conditions and were to be accessible to recreational, health, educational, and commercial facilities. Sites were not to show ethnic discrimination characteristics. Finally, the travel time and cost of going to and from work was not to be excessive (Galbraith, et. al., 1975, 1-7).

In the next chapter, Portland's translation of the goals and objectives of the congressional Housing and Community Development Program into a nationally recognized rehabilitation policy will be described. As will be seen, Portland incorporated many of the lessons learned from earlier rehabilitation efforts into its neighborhood rehabilitation progran process. The Impact of the program is not as obvious. Chapter V outlines the methods used in this study to monitor the program process and to discover exactly what the impact of the program has been on loan neighborhoods and their residents. 
CHAPTER IV

\section{PORTLAND'S LOAN PROGRAM}

In 1968, Austin Ranney isolated five components of public policy: 1) a particular object of set of objects intended by the policymakers to be affected; 2) a desired course of events or a goal; 3) a selected deliberate line of action; 4) a declaration of intent; and 5) an implementation of intent (Ranney, 1968:7). Portland's translation of the goals and objectives of the Housing and Community Development Act of 1974 into policy offers classic examples of each of the above components.

A central object of the city's Community Development Flan was to upgrade Portland neighborhoods facing possible decline, thereby preventing slums and blight and benefiting low and moderate income persons. Desired goals Iisted by the Office of Planning and Development included maintaining and promoting racial, income, and age diversity of people, housing alternatives, and neighborhoods; increasing homeownership opportunities; broadening rental choices; assisting in the major rehabilitation of housing; and encouraging individual owners and private investors, builders, and developers to accept the responsibility for the majority of home rehabilitation.

In the short run, preventing abandonment or lone term vacancy of housing units was called for. As a deliberate line of action, a thousand housing units were to be rehabilitated every year. Areas where maximum results could be realized were designated and a process for marketing and implementing several loan programs was developed. 
Nedighborhoods were to be researched for evidence of physical deterioration. Statistics sunmarized by the Office of Flanning and Development showed that deterioration and threats of deterioration were present in the city. In 1975, $29 \%$ or 42,540 units of all occupied housing units in the city were considered inadequate by virtue of crowding, age, condition, and/or cost in relation to income. Major rehabilitation was deemed necessary for 5.1\% (7,907 units) and an additional 15.1\% (29,800 units) were defined as physically substandard (Portland, Oregon, Office of Planning and Development, 1978:1-3).

Elght conditions were held to be particularly important in deciding where target areas would be s declining housing conditions and values, substandard and blighted housing; increasing turnover in ornership and/ or occupancy; insufficient incomes to maintain property; social and/or economic instability; unstable conditions crused by changes in land use and zoning; declining physical facilities and services in the neighborhoods; and peripheral forces having a negative effect on an area (Fortland Development Comission, 1978,1).

Together with the Portland Development Cominission, the office of Planning and Development declared the city's intent of maintaining and inproving the quality of urban neighborhoods in Portland and preserving and enhancing commercial and industrial areas of the city. Finally, implementation of that intent consisted of nine broad steps:

1. Prepare neighborhood "pre-planning studies" which compile and analyze physical, socio-conomic, and neighborhood condition data. Identify potential target area boundaries and impact areas.

2. Review data and staff findings and recommendations. 
3. Sample survey rehabilitation areas and systematically canvass preliminary impact areas.

4. Review survey and canvassing results and determine rehabilitation and impact area boundarles.

5. Establish rehabilitation area boundary and authorize undertaking of assistance programs.

6. Concentrate marketing of rehabilitation programs and related project improvements in target areas. Inform residents in balance of rehabilitation areas of program avallability.

7. Qualify applications for rehabilitation assistance, initiate and undertake improvements, certify compliance to code and contract.

8. Design, let contracts, and undertake project improvements.

9. Evaluate prozram implementation.

Four subsidized homeowner loan programs, the focus of this work, form one part of Portland's Local Housing Assistance Plan. Deferred Fayment Loans, or DPLs, are especially aimed at lou-income households. The purpose of the DPIs is to provide interest-free financing for meeting local housing code requirements. Up to $\$ 4,000$ can be awarded. Recipients pay no interest rate. Moreover, payment of the loan itself can be deferred until the property is sold or its omerahip transferred to someone else. Locally funded $\mathrm{HCD}-3$ and federally funded 312 loans are also geared towards bringing property into compliance with the city codes. Under these prograns, a household can receive up to $\$ 17,400$ for a single family residence as long as the household's income falls under given amounts. In contrast to the DPLs, these two loan types charge a nominal interest rate, and they must be repaid within a twenty-year perlod. A fourth loan, the Public Interest Ionder loan (PIL) could also 
be used for rohabilitating property up to housing code compliance, but unlike the other three loan programs, PIL loans can also be used for refinancing. As with the HCD-3 loans, a household can receive up to $\$ 17,400$ for a single family residence. In addition, PIL loans carry a $6 \frac{1}{2} \%$ interest rate and are to be repaid within 20 years.

In planning HCD-related activities, the city first considered several primary bodies of Information: the 1970 census, local surveys of housing conditions, and the regional goals and objectives developed by the Columbia Regional Association of Governments. Several housing trends were revealed which led to a strong emphasis on housing related HCD goals for the city. Twenty-nine percent of all occupled housing units were found to be inadequate in terms of condition, crowding, age, value, or cost in relation to value. Of these, five percent were physically deterlorated to an extent where major rehabilitation was required. An additional $15 \%$ were physically substandard to a somewhat lesser extent, requiring moderate degrees of rehabliltation. Twenty seven percent of the housing stock did not neot minimum housing codes. About three-fourths of both ormer occupied and renter occupled housing units had been built before 1950. Of the total inadequate units, $42 \%$ were occupled by elderly. The vacancy rate for all housing was less than 3\%. Construction of new units was at an extremely low level, with no substantial improvenent expected in the near future. The proportion of owner occupied inner city housing units was decreasing, from $57 \%$ of homeowners in 1950 to $52 \%$ in 1970. To meet all foreseeable needs, the clty's housing stock would have had to Increase by nearly 11,000 new units in a three year period. Yet the average and minimum cost of new family homes was rising even more rapidly 
than annual inflation. Even at $\$ 30,000$ each for new units, a total

expenditure of some $\$ 320$ million would be needed (Community Development

Block Grant Plan, 1975). It is littie wonder that rehabilitation, a

cheaper approach, found support.

The city's Office of Planning and Development presented the follow-

Ing long-term goals as the core of its Community Development Plans

1. Kaintain and improve the quality of residential neighborhoods in the City of Portland by

a. Greating and maintaining a growing inventory of safe and sanitary housing units at prices and rents which households of all incomes can afford-with special attention paid to the preservation of housing where deterioration is evident, though not acute. (Because housing quality is a cruclal determinant of nelghborhood quality and because Iimited public resources can be spread further if the deterioration has not progressed too far.)

b. Investing in public services, parks and public right-of-way in the residential neighborhoods of the city--particularly where such public improvements will occur in combination with private improvements. (Because public services, parks, and rights-of-way are important determinants of neighborhood quality, and because substantial improvements to residential neighborhoods will require much more than the limited public resources that are available for public improvements.

c. Arakening a sense of community pride among the residents of Portland's neighborhoods. (Because resident's attitude about his neighborhood is at least as important as the physical quality of that nelghborhood, and because his attitude must be positive if he is to invest his resources--time and money--in that neighborhood).

2. Preserve and enhance the commercial and industrial areas of the city--particularly where such efforts will expand economic opportunity for the lower income residents of the city, will promote private investment, or private non-divestment. (Because the nonresidential areas of the City contain the jobs at 
which residents are employed and, in addition, provide a substantial part of the tax base from which a portion of the public resources must come to support investments in the residential neighborhoods.)

The neighborhood unit was to be central to the basic policy of the city and also to the concept of revitalization. The city's strategy for 1mplementation of the plan was stated in the Community Development Block Grant Plan: "To select a few neighborhoods each year which can demonstrate...the possibility of stabilizing population and housing trends" (Community Development Block Grant Plan, 1975:5). The strategy was further detailed by Kayor Neil Goldschmidt at a City Council hearing In February, 1975. At that meeting, the mayor emphasized that the amount of dollars Fortland would be allocated by HCD was inadequate to meet all housing needs within the city. Therefore, the most visible means of attaining some measure of success would be to concentrate funding in a few neighborhoods each year, with the intention of stimulating investment from benks and other investors within those neighborhoods.

The city's Housing Assistance Flan proposed two basic goals for housing in the city: 1) to reduce the isolation of income groups within communities and geographic areas, and 2) to promote the vitality and diversity of neighborhoods through the development and expansion of housing oppoitunities throughout the c1ty for persons of lower income. Housing improvement was given top priority, with rehabilitation scheduled to take place in several target areass

1. Concentrate HCD expenditures in high inpact, identifiable areas for maximum effectiveness. Initially concentrate efforts in neighborhoods where deterloration is evident but not acute. Fforts will include activities to improve housing and public facilities, and to eliminate and prevent further deterioration. 
2. Ut1lize HCD funds, where possible, as leverage to stimulate additional public and private investment. Expansion of economic opportunities for the citizens of Portland and reinforcement of the City's commercial and industrial areas...

3. Carry out small scale projects of spectal interest or unusual circunstances outside of participating neighborhoods in response to community development needs that cannot be alleviated through other means... (Galbraith et. al., 1975 \& F-5).

To select target neighborhoods which would acknowledge both federal and local program directives, nine factors were examined which taken together, provided a profile of conditions generally signifying the first phases of urban decline. Each factor was measured on a scale of 1 to 5 . Census tracts rating 4 or more points per factor were above the city average for that item. Conversely, those rating three or less were below city average. If an area had a total of 36 points or more, it was usually above averaze in all factors measured. Table II provides an example of the worksheet used to profile each neighborhood in the city. Table III shows a comparison of the St. Johns and Richmond neighborhoods with the city as a whole.

Based on the above point count, the following categories were determined:

Limited Assistance: 36 points or more OR above the median income

Concentrated Assistance: 35-26 points

Special Assistance: 25-15 points

Maintenance Assistance Concentrated areas having already recelved 3 years HCD assistance or more. Limited areas that have 36 points or more but are belok median income. 
TABIE II

NINE FACTORS AFFECTING DELIVERY OF HCD CAPITAL IMPROVEMENTS AND REHABILITATION ASSISTANCE PROGRAMS

Factor

1. Housing in Single Family Units 8 of total units - City average $74 \%$

2. Owner Occupants $\%$ of total households - City average 588

3. Change in Occupancy 8 of total housing units City average $34 \%$

4. Vacant Housing Units 8 of total units - City average $6 \%$

5. Housing Units

\begin{tabular}{|c|c|c|c|c|}
\hline \multicolumn{5}{|c|}{ Points } \\
\hline 5 & 4 & 3 & 2 & 1 \\
\hline$\emptyset$ & $100-758$ & $74-508$ & $49-25 z$ & $24-08$ \\
\hline $100-80 \%$ & $79-608$ & $59-408$ & $39-208$ & $19-08$ \\
\hline $0-198$ & $20-34 \%$ & $35-498$ & $50-648$ & $\begin{array}{l}658 \text { and } \\
\text { over }\end{array}$ \\
\hline $0-28$ & $3-68$ & $7-128$ & $13-208$ & $\begin{array}{l}218 \text { and } \\
\text { over }\end{array}$ \\
\hline $\begin{array}{l}25 \text { or more } \\
\text { increase }\end{array}$ & $\begin{array}{l}1 \text { to } 24 \\
\text { increase }\end{array}$ & no change & $\begin{array}{l}1 \text { to } 24 \\
\text { decrease }\end{array}$ & $\begin{array}{l}25 \text { or more } \\
\text { decrease }\end{array}$ \\
\hline
\end{tabular}




\section{TABLE IT (Continued)}

NINE FACTORS AFFECTING DELIVERY OF HCD CAPITAL IMPROVEMENTS AND

REHABILITATION ASSISTANCE PROGRAMS

Factor

6. Population

7. Households with Children

8 of total households City average $28 \%$

8. Jobless Head of Household 8 of total household City average 98

9. Household Income City average $\$ 10,825$
5

$\begin{array}{ll}75 \text { or more } & 1-74 \\ \text { increase } & \text { increase }\end{array}$

$40 \%$ and over

$0-48$

158 and

more above

average
Points

3

1

75 or more decrease

decrease

$9-08$

$39-308$

$29-208$

$19-108$

$5-98$

$10-148$

$15-20 z$

218 and

over

$1-148$
above
average

same as

above
1 - $14 \%$
below

158 and

average

average

more below

average

Source: City of Portland, Portland Development Commission (1975). Internal Files. 
TABLE III

A COMPARISON OF FACTORS AFFECTING DELIVERY OF HCD CAPITAL IMPROVEMENTS AND REHABILITATION ASSISTANCE PROGRAMS: PORTLAND, ST. JOHNS, AND RICHMOND

Factor

1. Housing in Single Family Units s of total units - City average 748

2. Owmer Occupants

8 of total households -.

City average $58 \%$

3. Change in Occupancy

$\%$ of total units -

City average 348

4. Vacant Housing Units

8 of total units -

City average 6\%

5. Housing Units

6. Population

$$
\text { Portland }
$$

748 (3)

58 (3)

$34 \%$ (4)

6\% (4)

No change (3)

No change (3) st. Johns

758 (4)

608 (4)

$35 \%$ (3)

$6-78(3.5)$

$1-24$ inc. (4)

$1-74$ inc. (4)
Richmond

758 (4)

$58 \% \quad(3.75)$

$30 \%$ (4)

$3-68$ (4)

$1-24$ inc. (4)

75 or more inc. (5) 
TABLE IIT (Continued)

A COMPARISON OF FACTORS AFFECTING DELIVERY OF HCD CAPITAL IMPROVEMENTS AND REHABILITATION ASSISTANCE PROGRAMS: PORTLAND, ST. JOHNS, AND RICHMOND

Factor

7. Households with Children

28 옹

$35 \%$ (4)

$308 \quad(3.75)$

8 of total households -

City average 28\%

8. Jobless Head of Household

98 (3)

$10 \% \quad(3)$

98 (4)

$\&$ of total heads of household City average 9\%

9. Household Income

City average $\$ 10,825$

Average (3)

1 - 148 below

average (2)

1 - $14 \%$ below

(2)

points are in parentheses

Total

31.5 points

34.5 points

Source: City of Portland, Portland Development Commission (1975). Internal Files. 
If, using the point count, an area was predominantly composed of persons living in single family dwellings, with high ormer-occupancy, few vacancies, little turnover in population, high levels of employment, and displaying above median income, then only limited assistance would be needed. Programs avallable to those areas were to include critical home repairs for low income households, voluntary housing code inspection, and optional activities based on unique or specific needs, such as a traffic signal or some park improvements. If all the preceding factors Iisted remained nearly the same but the area was below median income, it would be an area where concentrated assistance would be avajlable to rehabilitate housing and make necessary public inprovements possible. In such areas, conditions warranted door to door marketing of housing rehabilitation assistance and public street improvement programs. Other public improvements could include new or expanded parks, street trees, and traffic signals. It was felt that considerable staff and nelghborhood effort would be needed to bring about as much upgrading of the neighborhood environment as possible.

Neighborhoods which scored low on all factors cited needed more help than was possible through HCD activities alone. Such areas tended to be primarily non-residential or to have a high proportion of low income families, were severely blighted, or performed a special function, such as the downtown or central eastside industrial area. HCD assistance was to be combined with other resources for a more effective progran. Figure 1 shows the areas determined to be best suited for HCD funds.

Central to the city's plans, four subsidized home-omer loan prograns were instituted as a means of financing rehabilitation in the designated HCD neighborhoods (see Table IV). Most of the programs were 


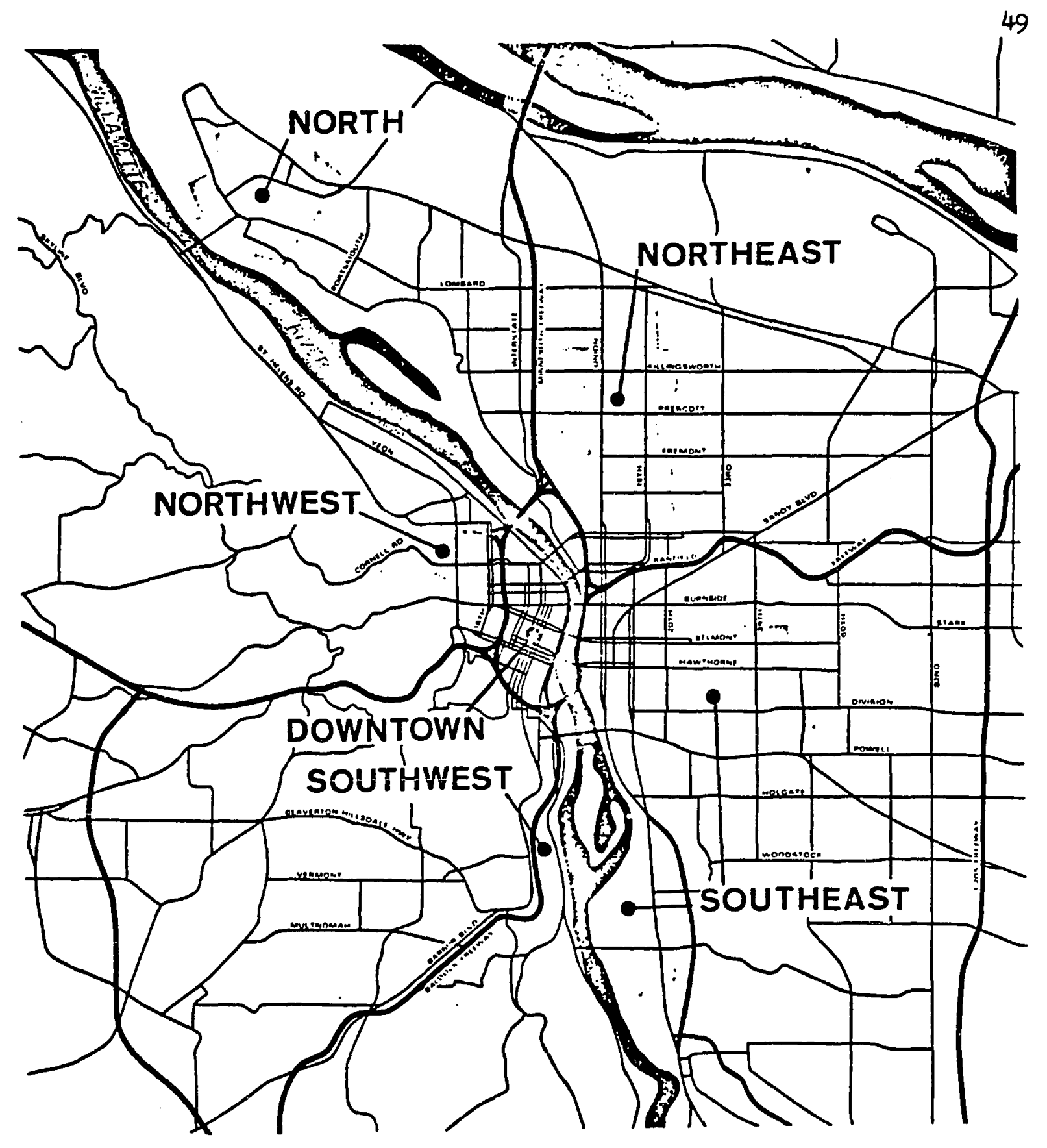

\section{HOUSING AND COMMUNITY DEVELOPMENT AREAS CITY OF PORTLAND, ORE.}

FIGURE 1 
TABLE IV

HOUSING ASSISTANCE PROGRAMS - PORTLAND, OREGON

Purpose

DPL

Rehabilitate home to meet all applicable housing codes and ordinances
Amount Available

Conditions

$\$ 4,000$; cost of rehab; or amount of equityl, whichever is less
Owner-Occupant Fee simple title; or Contract purchaser (obtained interest 1 year prior to application). Income limits

Same as above with the ability to repay loan. single family residence; cost of rehab; or amount of equityl, whichever is less.

\begin{tabular}{lll}
\hline HCD-3 & Bring property & $\$ 17,400$ for \\
312 & into compliance & single family \\
with City codes, & residence; cost \\
& Standards and & of rehab; or \\
needs of the & amount of \\
household & equityl, which \\
& ever is less.
\end{tabular}

PIL Cost of rehabili- Same as above

tating property

up to housing

code compliance:

provides for

refinancing

lEquity will be measured by subtracting the total indebtedness secured by the property tax from the assessed market value as shown on the most recent property tax appraisal of the property by the County Assessor.

2 Housing and Community Development.

Source: City of Portland, Portland Development Commission (1976). "Rehab Cookbook: A Guide to financing and Contracting for Home Improvements". 
to be funded federally. The PIL program, on the other hand, is a locally established program where rehabilitation funds are provided by a consortium of eleven local lending institutions?. Because funds loaned to the Development Commission for the PII loans are tax exempt, the institutions have been able to make funds available at below-market interest rates. The funds are also federally insured.

Table $V$ classifles funding sources for the four programs from 1975 through 1978.

\section{TABIE V}

PROGRAM FUNDING SOURCES

$$
\text { 1975-1976 1976-1977 1977-1978 TOTAL }
$$

HCD Block

$\begin{array}{lllll}\text { Srant } & \$ 1,269,092 & \$ 2,162,877 & \$ 2,937,909 & \$ 6,369,878\end{array}$

Section $312 \quad \$ 1,238,750 \quad \$ 2,369,700 \quad \$ 4,273,250 \quad \$ 7,881,700$

Private

Ienders $\$ 1,500,000 \quad \$ 2,000,000 \quad \$ 3,138,850 \quad \$ 6,638,850$

Total Rehab \$4,007,842 \$6,532,577 \$10,350,009 \$20,890,428

Sources City of Portland, Portland Development Commission 1978, p. 13.

The Portland Development Commission was given the role of implementing the loan programs :

\footnotetext{
Planning, programing, resource allocation, and program implementation, management, and evaluation will be directed and coordinated by the Office of Planning and Development. The Portland Development Commission will be the prime implementation agency, with the cooperation of the Bureaus of Planning, Buildings, Public Works, Parks, Human Resources, Management and Budget, and others (Community Development Block Grant Plan, 1975: Part $I, 6$ ).
} 
THE PORTLAND DEVELOPMENT COMMISSION

For institutional context, the Portland Development Cosmission was established by the voters in 1958 as the city's Department of Development and Civic Promotion. Under Rasolution 27526, the Commission was to be administered by five members appointed by the mayor. Figure 2 shows PDC's position in city governnent. Serving as the urben renewal and rodevelopment agency of the city, the Commission was given power to perform all renewal activities, including preliminary studies of possible urban renewal areas, formulation and implementation of urban renewal and redevelopment plans, acquisition by purchose, condemnation or otherwise, property within an urban renewal area, or whero acquisition was necessary to carry out a redevelopment plan to provent, renove, or reduce blight. From its inception, the Commission has had the power to borrow money, negotiate federal advances of funds and execute notes as evidence of obligations. The City Council has the power to make loans to the Commission from any available city fund. Revenue bonds may be issued for Comission activities, or the city can levy a tax of $2 / 3$ rds of one mill on each dollar of assessed valuation on property not tax exenpt within the city to provide funds for Commission expenses.

The Comission has been vary active from its start. Its activities can be classified into five types, redevelopment, neighborhood rehabilitation, neighborhood development programs, pre-project planning and neighborhood assistance, and general aid.

Early efforts at neighborhood rehablittation centered largely around the Albina Neighborhood Inprovement Project. Pesidents of the area Improved and constructed streets, alleys, curbs, and sidewalks, 
FIGURE 2

LOCAL GOVERNMENT STRUCTURE, PORTLAND, OREGON

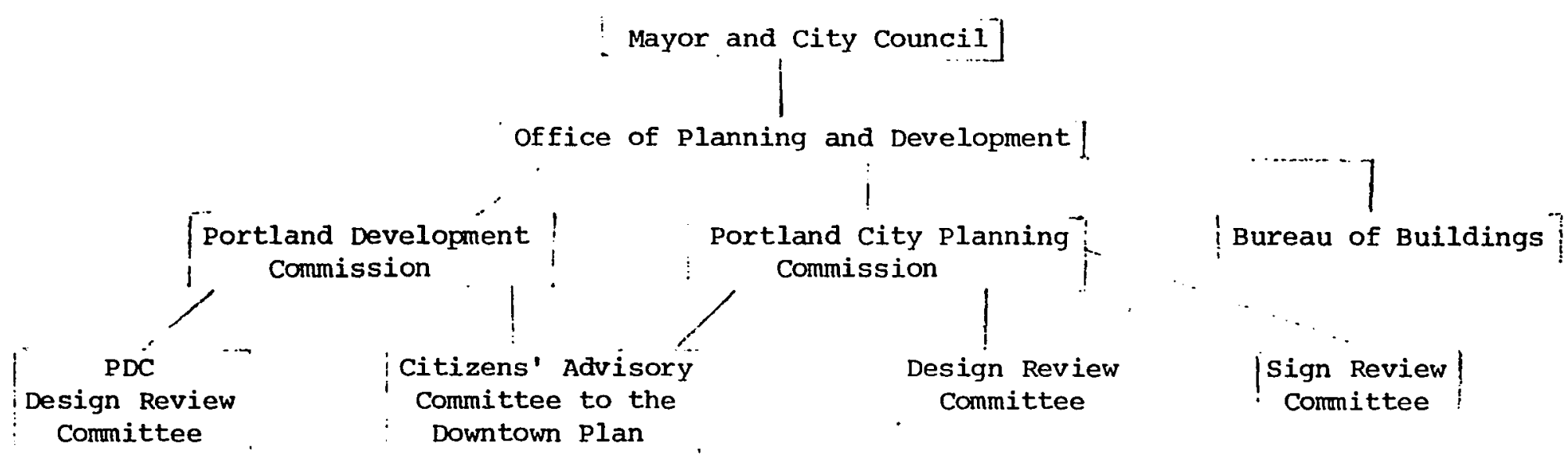

Source: Portland Development Commission, 1978. Internal File. 
planted over a thousand trees, and removed utility poles and overhead lines even before there was any federal financing of the project. Unthank Park was constructed with the help of nelghborhood people. In the same district, neighborhood development prograns provided loans and grants to owners for the rehabilitation of their homes while other activities included improving or constructing curbs, sidewalks, streets, street light installation, park development, and creating sites for construction of low to moderate income housing. To augment nelghborhood development programs, pre-project planning and other neighborhood assistance was often provided. The Southeast Uplift program and the St. Johns Peninsula program were developed to help residents improve city services in the area. FDC also worked with both Euckman and the CorbettTerwilliger ereas to develop inprovement plans.

\section{THE LOAN PROCESS}

With the advent of the Housing and Community Development Act of 1974, the Comnission stepped up its efforts at neighborhood rehabilitation. Since 1975, well over three thousand housing units have been rehabilitated through HCD and local programs, at a cost of over $\$ 17$ million dollars (see Tables VI and VII). No other American city has accomplished even half that number of rehabilitated units. According to the Development Comission, two factors are most influential here. First, the loan prograns are flexible. People with different needs and resources are eligible for a varlety of loans tailored to their personal circumstances. As an example, people with low incomes (in 1978, $\$ 6,750$ annually for a fanily of two) and a few assets tend to be directed toward deferred payment loans of up to $\$ 4,000$ for rehabilitation work. For 
TABLE VI

SINGLE-FAMILY HOME REHABILITATION LOANS, PORTLAND, OREGON

$\begin{array}{cccc}\begin{array}{c}\text { Fiscal Year } \\ 1975-76\end{array} & \begin{array}{c}\text { Fiscal Year } \\ 1976-77\end{array} & \begin{array}{c}\text { Fiscal Year } \\ 1977-78\end{array} & \text { TOTAL } \\ 12 & 18 & 25 & 25 \\ 604 & 603 & 1,315 & 2,522 \\ \$ 3,257,886 & \$ 5,486,895 & \$ 8,551,985 & \$ 22,880,894\end{array}$

Source: Portland Development Commission (1978) 2nd Decade:13 
TABLE VII

GROWTH OF HOUSING REHABILITATION PROGRAM, PORTLAND, OREGON

$\begin{array}{lcccc}\text { Fiscal Year } & 1975-76 & 1976-77 & 1977-78 & \text { TOTAL } \\ \begin{array}{l}\text { Number of Estimated } \\ \text { Dwelling Units Assisted }\end{array} & 725 & 991 & 1,508 & 3,224 \\ \begin{array}{l}\text { Dollar Amount } \\ \text { N }\end{array} & \$ 3,257,886 & \$ 5,486,895 & \$ 8,551,985 & \$ 17,296,766\end{array}$

Source: Portland Development Commission (1978) 2nd Decade:13. 
such loans, no interest is charged and the loans do not have to be repaid until a housing unit changes hands. A two-person household eaming up to $\$ 13,500$ can borrou as much as $\$ 27,000$ with an interest rate of $3 \%$. Since their financial status is higher, they can be expected to pay some interest, making it possible to receive higher loans. For a I1st of the eliglbility criteria, see Table VIII.

The second reason for such a large number of rehabilitated units has been the loan process. Prior to considering any loan applications, PDC developed an aggressive marketing plan for its programs. In most HCD areas, representatives of the agency walked door to door six days a week to tell people about the program. Ietters were also sent out to HCD neighborhood residents while public notices were posted periodically in the newspapers and on the radio and television. An example of the letter sent to residents is enclosed in the Appendix.

Homeowners showing interest in the program face a loan process of seventeen steps. First, a general application is completed, in which applicants provide information about themselves including marital status, age, children, and employment information. Information about the property to be Improved is also given, Including purchase price, present balance, to whom the balance is payable, and date of purchase. Assets and 1iabilities are Iisted, as are charactieristics of the house, such as square footage and type of heating. An application can be found in the Appendix.

From there PDC matches up applicant information with eligibility requirements and notifies applicants by mail of their eligibility status. For those determined to be eligible for a loan, a PDC representative inspects the applicant's property to determine if any housing conditions exist that endanger, or might endanger, that person's health and safety 
TABLE VIII

INCOME LIMITS: REHABILITATION LOAN PROGRAMS

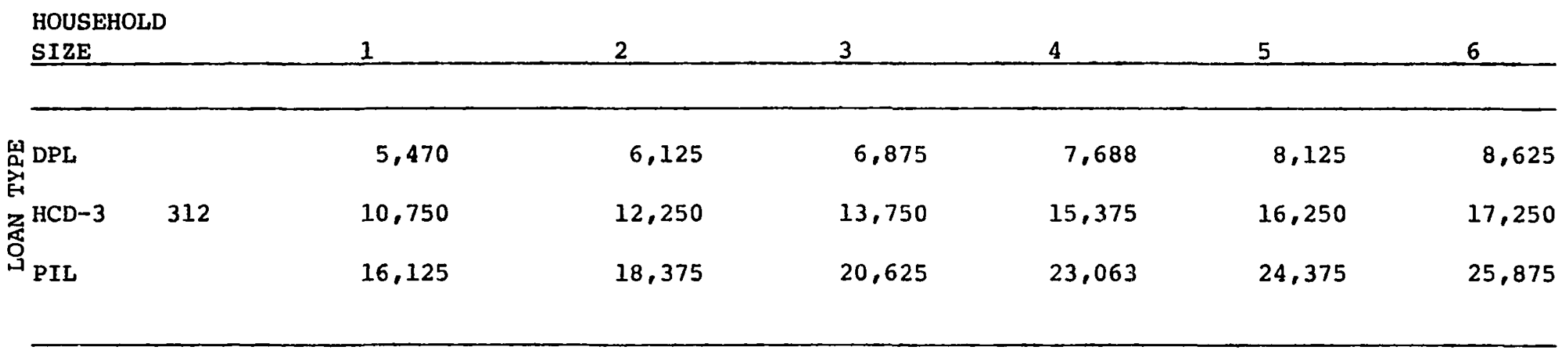

Source: City of Portland, Portland Development Commission (1977)

"Housing Assistance Programs: City of Portland, Oregon" 
or his or her financial investment in the housing unit according to Title 129 of the Housing Regulations for the City of Portland. A 11st of deficiencies, if any, is given to the applicants together with a list of rehabilitation activities that can be covered under the loan program. Options include nine categories which can be found in the Appendix. The agency provides a rehabilitation specialist to prepare rehab1litation specifications and cost estimates once an applicant has decided to take part in the loan program. (An example of the Rehab Spec is enclosed in the Appendix.) At the same time, loan progran participants are given a list of contractors who have asked to participate in the city's rehabilitation programs. When the rehabilitation speciflcations are finished, bids from selected contractors are requested. Plans and prepared work speciflcations are used as a basis for the bids. Contractors are selected according to bids. Homeowners having some rehabilitation experience themselves have also acted as contractors. At that point, plans, specifications, and breakdows, together with the contractor's bid and signed acceptance of the contract documents are prepered by the Commission's housing assistance staff. The loan is closed, rehabilitation contract signed, and work performed. Building permit completion certifications and an inspection by soneone from PDC's housing assistance office insure that the conditions of the rork contract have been met. An omer's Acceptance Certificate and authorization for the Commission to pay the contractor is then signed by loen recipients. The only other step in the process is payback of the loan over a 20-year period, where applicable, or when the particlpant's home changes ownership. Assorted documents central to the process can be found in the Appendix. Taking all HCD prograns together, over 36 million dollars have been 
funneled into Portland. The figures in Table IX show the proportion of funds going into rehabilitation efforts. As indicated, the total funds Increased substantially through the course of the program.

For St. Johns, one of the two HGD target neighborhoods in the present study, almost two million dollars was filtered into HGD activities in the first three years of the Housing and Community Development program. Half that sum went to business area improvements, including construction of the St. Johns garage, Cathedral Park access, the construction of ten miles of streets, four major traffic signals, an astronomy center, street lighting, ans trees. The sum of 1.6 million dollars went toward improvement loans for approximately 300 homes. For Richmond, the other HCD neighborhood to be surveyed, the amount was under a million dollars, with an estimated $\$ 100,000$ going to such improvements as Seawall Crest Park, public works, and trees.

\section{Footnotes}

1. The lending Institutions included the United States National Bank of Oregon, First National Bank of Oregon, The Bank of California, Benjamin Franklin Savings and Loan Association, First State Eank of Oregon, Oregon Ploneer Savings and Loan Assoclation, Canadian Imperial Bank of Commerce, Fred Neyer Savings and Loan Association, Cascade Federal Savings and Ioan Association, Oregon Trail Savings and Ioan Association, Equitable Savings and Ioan Association, Oregon Mutual Savings Bank, The Oregon Bank, and Pactfic First Federal Savings and Ioan Association. 
TABLE IX

PERCENTAGE OF FUNDING FOR SPECIFIC HCD ACTIVITIES, PORTLAND OREGON

\begin{tabular}{|l|l} 
Year \\
Rehabilitation Loans \\
Acquisition \\
Relocation \\
Matching Funds \\
Planning \\
Administration
\end{tabular}
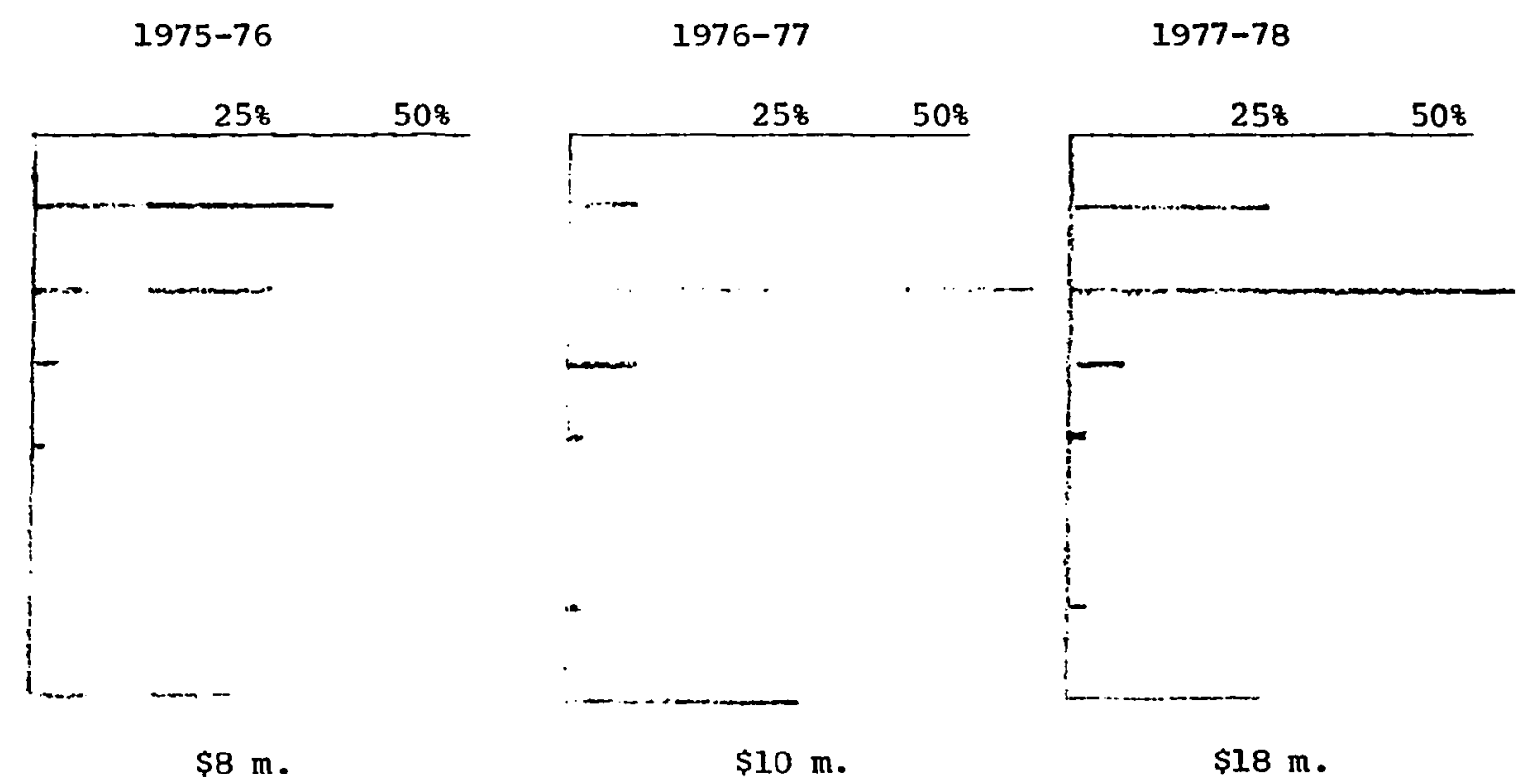

Total (Includes $312 \& \mathrm{PIL}$

$\$ 8 \mathrm{~m}$.

$\$ 10 \mathrm{~m}$.

$\$ 18 \mathrm{~m}$.

Note: About 2/3rds of Administration is directly attributable to operating the Rehabilitation Loan Program.

Source: City of Portland, Office of Planning and Development (1978). Office Memo. 


\section{CHAPTER V}

\section{METHODOLOGY}

Two central research topics stem from the goals and objectives of Portland's Community Development program. First, the process needs to be evaluated according to how closely it fulfills the criteria for a successful rehabilitation program as outlined in Chapter III. Its acceptance by loan recipients needs to be evaluated. Second, there is the issue of program impact. One aspect of impact revolves around the question of whether or not those populations benefiting from city efforts were indeed low and noderate in income, as intended by the Housing and Community Development Act of 1974. Second, an assessment of the impact of the rehabilitation loan programs on attitudes toward neighborhood livability provides an important indicator of the overall effectiveness of the programs. In addition, several non-attitudinal measures exist such as changes in mortgage loan activities in HCD neighborhoods since 1975. which can provide an alternative perspective on program impact.

\section{PROCESS EVALUATION}

Chapter IV showed that Portland incorporated lessons learned from earlier rehabilitation efforts into its neighborhood rehabilitation programs. Each c1ty neighborhood was closely researched regarding 1ts social and economic characteristics before it was ever decided which neighborhoods would most benefit as HCD neighborhoods. A door-to-door marketing campaign demonstrated the agency's concern with keeping 
residents informed of the programs. Detailed appraisals of both applicants and their homes were made to guarantee that rehabilitation efforts could be maintained. Counseling and help with work write-ups were included along with financial assistance for each loan recipient. Feedback mechanisms in the form of in-house evaluations were developed to monitor the progress of the program. Lastly, of all the methods available for providing rehabilitation assistance, direct loans using HCD funds and interest subsidized loans where local lending institutions were partially paid back with HCD funds were selected as the means through which the city could most feasibly finance the programs.

\section{Secondary Sources of Data: Internal Evaluations}

As for recipient evaluations of the process, the Development Commission regularly receives feedback from loan reciplents. In their evaluations, reciplents rate the services of PDC and their contractors, and declde whether the program is worth recommending to their neighbors. A search through the evaluation sheets of the loan reciplents profiled below showed strong support for the loan process. While only a little over a hundred persons in a group of 266 filled out the evaluations sheets, all but two rated PDC as good (62) or excellent (50). A cosmon comment made on the forms was that the progran was ideal for people who have pride in their homes and yet need assistance in keeping it up and in working order. Others wrote that the work done on their homes had cut their fuel consumption and costs in half.

Contractors were not rated as highly. While most of those who rated their contractors gave them "good" marks, only 28 persons rated a contractor excellent. Most of the latter were homeowners who had per- 
formed the contracting duties themselves. Another nine rated the contract work as fair, and three as poor. Nonetheless, all recipients but four would recomend the program.

The FDC in-house evaluations, while suggestive, offered no systematic indication of how loan recipients felt about the loan process. A significant number of recipients did not give any feedback, evaluation forms were redesigned nidway through the process, and many of the evaluations of the prosram were done over the telephone by the same PDC representative who worked with the loan recipients, offering an obvious source of bias in the evaluation. Further, none of the information on the in-house evaluations gave any indication regarding changes of attitudes toward recipient neighborhoods.

\section{The Neighborhood Survey}

To provide a confidential forum for receiving recipient evaluations of the loan process, the neighborhood survey described below asked recipients twelve questions related to the loan process. First, respondents were requested to rate the program generally. From there, questions were more specific, asking respondents to rate the services of the Portland Development Commission during the processing of the loans, to rate the work performed, and whether or not they would recomnend the program to their neighbors. (The questions can be found in the Appendix.) Their responses are reported in Chapter VI.

\section{PROGRAM EVALUATION}

\section{Sources of Date: Recipient Profiles}

The first steps taken to evaluate the impact of the loan program on 
Portland was to determine who those populations were who were benefiting from city efforts. Were they indeed Iow and moderate income, as intended by the Housing and Community Development Act?

To develop a profile of the loan recipients, a simple random sample $(n-266)$ was taken of Portland Development Commission recipient files for the single family home loans awarded between 1975 and 1978 ( $N=1770)$.. Time and resource linitations determined the size of the sample. Information on twenty-seven varlebles was collected. They are

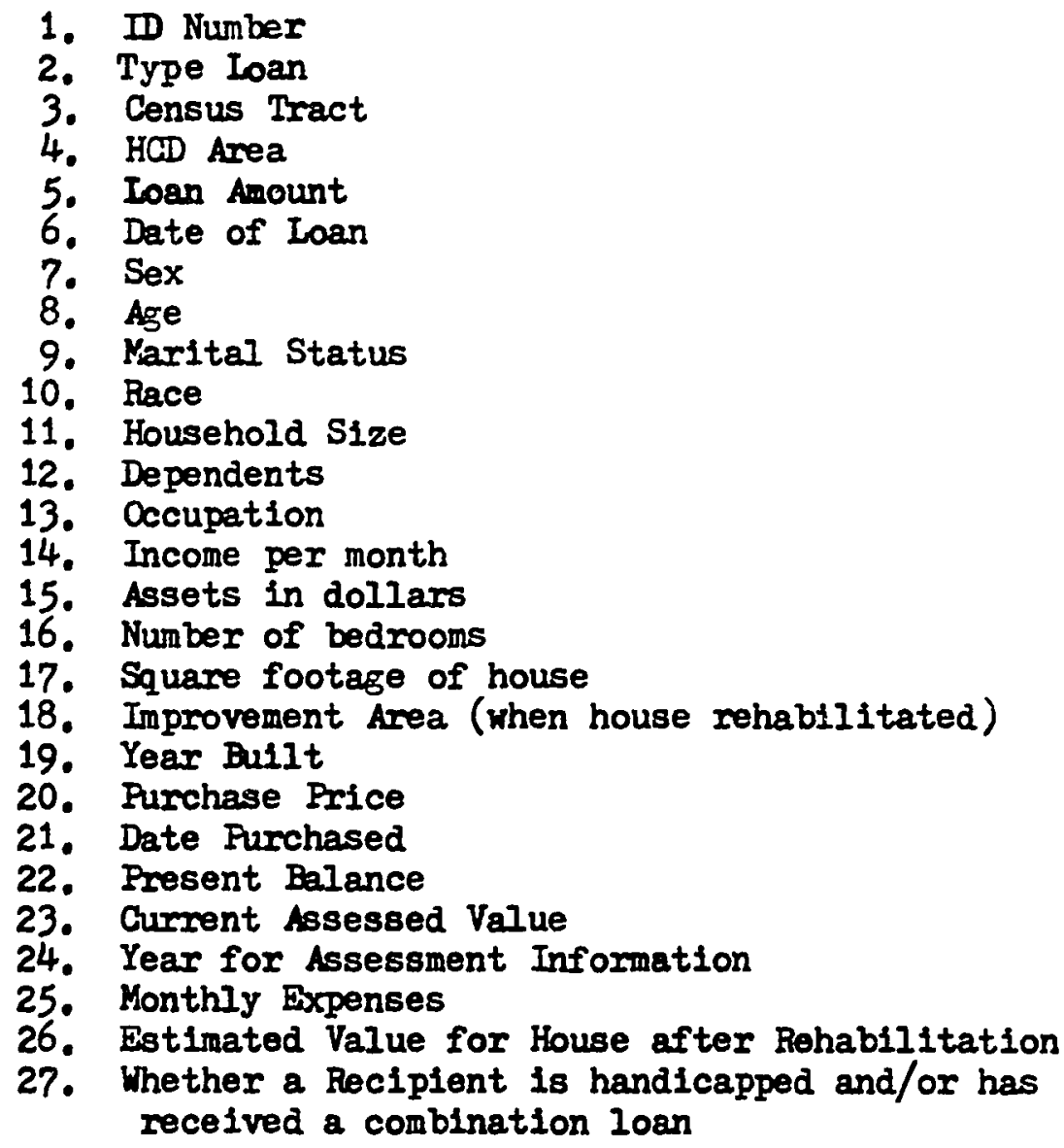

To facilitate statistical comparisons of loan-recipient profiles, the values of such variables as income per month, housing costs per months, and dollar assets were transformed into 1977 dollars. Adittional information about the variable coding scheme is provided in the Appendix. 
Chapter VII reports the findings of the internal file survey. There, Portland Development Commission loan recipients are profiled in detail comparing the socio-economic characteristics of the recipients of the different loan types offered by the city.

\section{Secondary Sources of Data: autside Perceptions}

One dimension of how the loan programs have impacted neighborhoods into which they have been funneled is how outside actors perceive those neighborhoods. In this study, two elements were used to indicate outside perceptions: real estate trends and mortgage and home improvement activities of the major savings and loan and banking institutions in Portland.

For real estate trends, the prices for homes in the study neighborhoods put on the market in July for the years 1975 through 1978 were compared for significant differences, using an analysis of variance techniques. Interviews with officers from thirteen savings and loan and banking institutions provided information on private loan activities in the neighborhoods for the last half of 1976, 1977, and 1978. The number of home improvement loans and home mortgage loans that were given in each of the study neighborhoods for that period were counted. Unfortunately, bank records of loan activities were not mandated prior to August 1976. The institutions providing data included, First National, Western, U.S. National, Far West Federal, Benjamin Franklin, Lquitable, Fred Neyer, Oregon Mutual, Cascade Federal, First State, Oregon Bank, Oregon Ploneer, and Orezon Trail. That data is reported in Chapter VIII. 
STATISTICAI METHODS

For both the process evaluation and program evaluation, contingency tables, several analyses of variance, median tests, and correlational analysis provided the statistical tools used for this study. The Appendix includes a description of each of these statistical techniques. Contingency tables provided a useful mechanism for relating information in an easy to read form. Such tables allow for an easier summarization of the information gathered in the recipient files and neighborhood surveys than would have been possible in a narrative. Because of the nature of the data, the following statistical tools were chosen as best suited to studying the relationships among the variables, F tests, eta ${ }^{2}$, the median test $\left(x^{2}\right)$, and Tau $C$ as an indicator of correlation. The survey instrument asked for responses according to categories such as very good, good, not so good, and not good. That, plus the tendency of much of the data to cluster, meant that often the assumptions needed for commonly used parametric statistical tests such as means tests could not be met. Instead, their nonparametric counterparts, developed for analyzing categorical data, were chosen as better suited to this study.

\section{IMPACT AND PROCESS: THE NEIGHBORHOOD SURVEY}

The primary data used for evaluating the Portland Developnent Commission rehablittation loan program came from a random sample survey conducted of 100 adults in each of four neighborhoods in Portland in January, 1979. Two Housing and Community Development neighborhoods, St. Johns and Richmond, were compared to two non-HCD neighborhoods, 
Portsmouth and Creston. A map of Portland showing the location of the neighborhoods and separate maps of each neighborhood follow. In the Interests of statistical accuracy, a sample larger that 400 may have allowed for more clearly delineated findings. Limited resources and the need to implement a survey in as short a time frame as possible for comparative purposes made a larger sample unfeasible. The Methods Appendix Includes a discussion of sampling errors related to the sample size. Tables $X$ and $X I$ show that the four neighborhoods chosen for the study closely resemble each other in terms of housing and socio-economic characteristics. All four showed signs of possible decline. From 1960 to 1970, all but Portsmouth (non-HCD) had dropped in ranking in terms of median income compared to the rest of the city. Out of 57 neighborhoods, Creston (non-HCD) fell from 25th to 34th, Richmond (HCD) from 31st to 35th, and St. Johns (HCD) from 23rd to 32nd. Home values as listed in 1975 ranked low, ranging from 25th place for Creston (non-HCD) to 34th for St. Johns (HCD). Portsmouth (non-HCD) and Richmond (HCD) ranked 28th and 29th respectively. Finally, gross rent figures for 1960 to 1970 showed all four neighborhoods falling in their rolative standing. Creston (non-HCD) rents fell from 2nd to 15 th place, Richmond (ECD) from 9th to 33rd, Portsmouth (non-HCD) from 22nd to 40th, and St. Johns (HCD) from 14th to 24th. Such major declines strongly suggest that the nelghborhoods were losing their appeal compared to the rest of the city overall, 1.e., they were experiencing decline or facing the possibility of decline (Portland, Oregon, Office of Flanning and Development, 1978:37-106). For this study, the four nelghborhoods were paired so that the two HCD neighborhoods, St. Johns and Rlchmond, could be compared with two non-HCD neighborhoods, Portsmouth and Creston respectively. Of the 18 


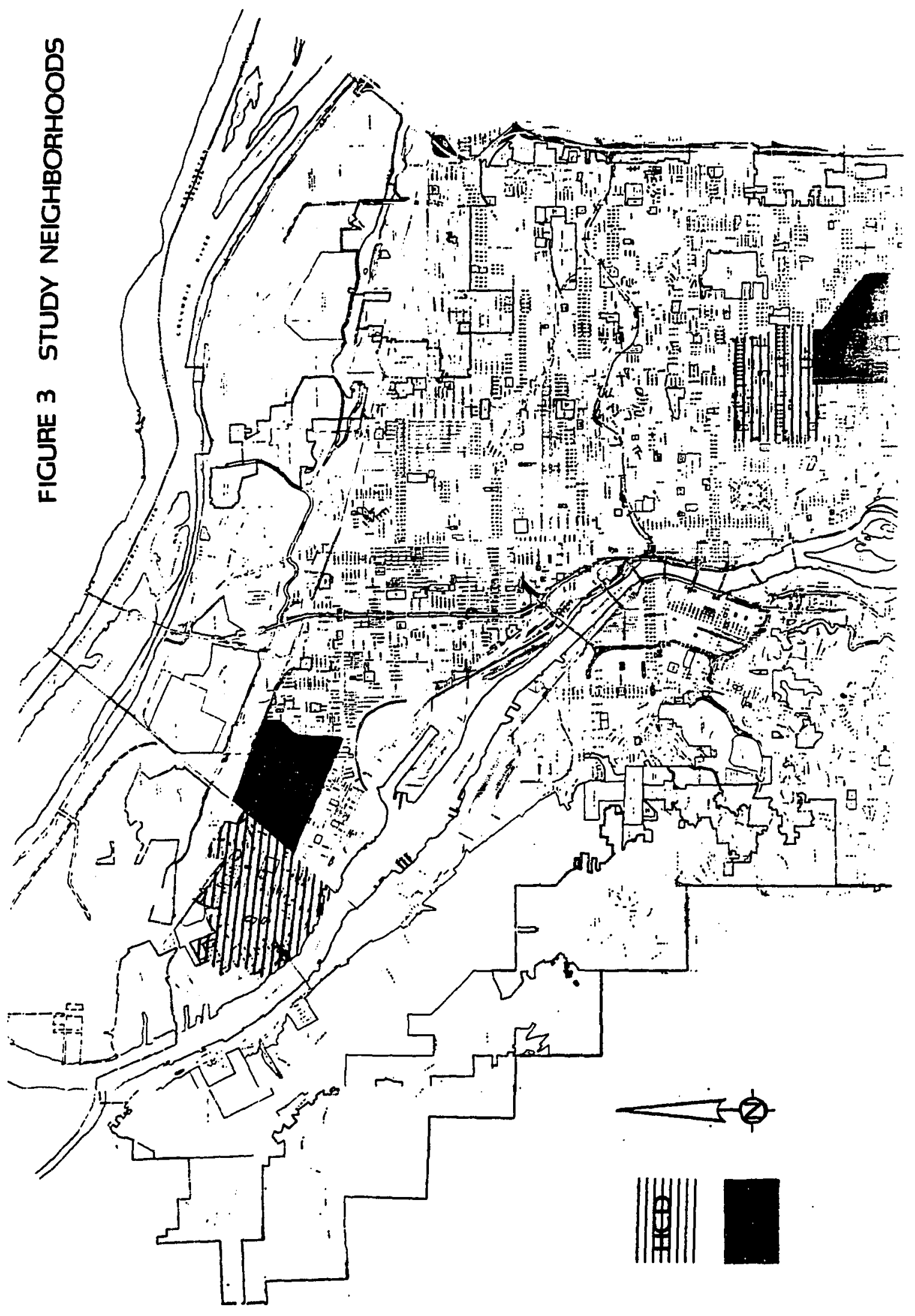




\section{ST. JOHNS \\ (HCD)}

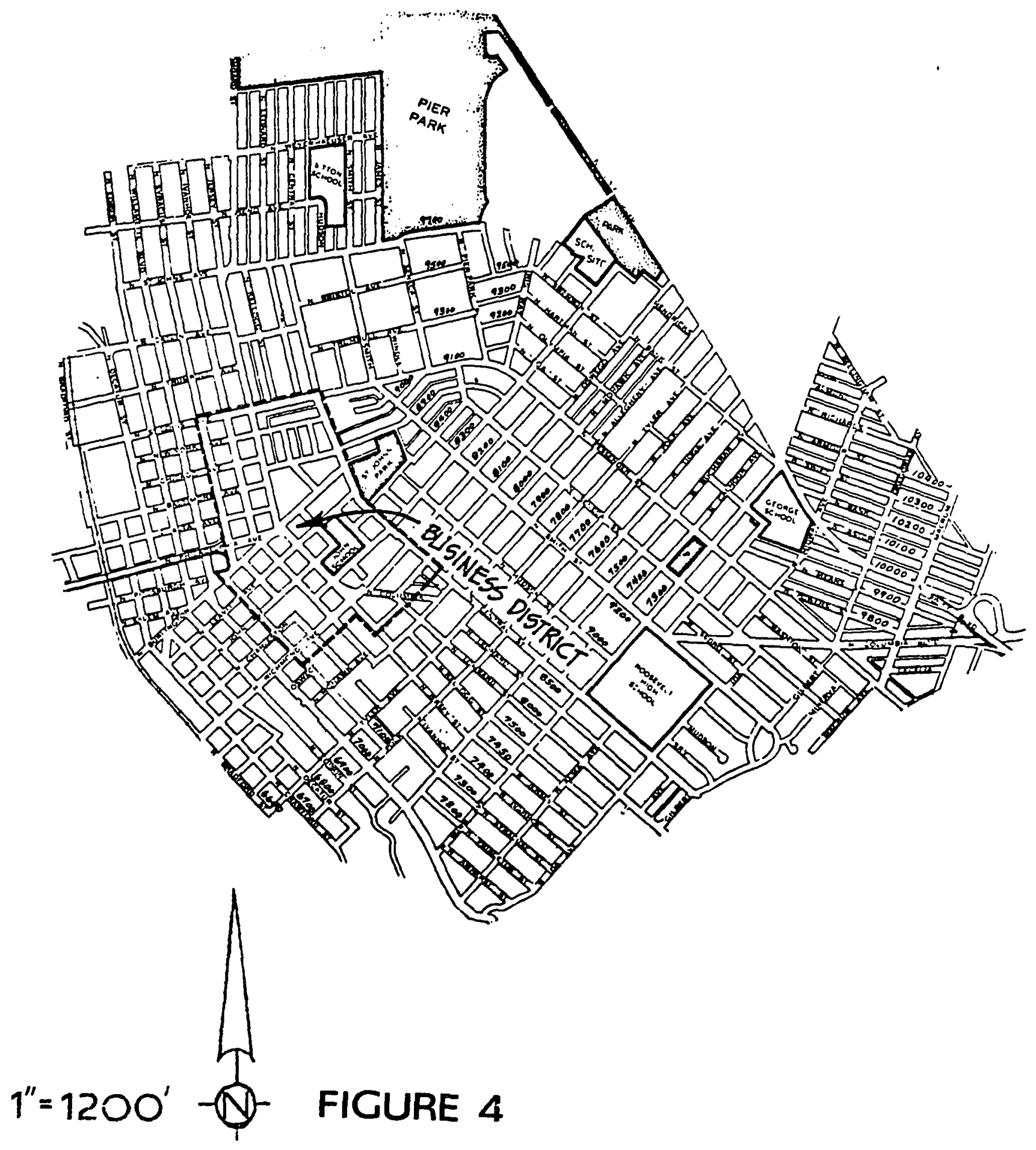




\section{BOUNDARY MAP PORTSMOUTH}
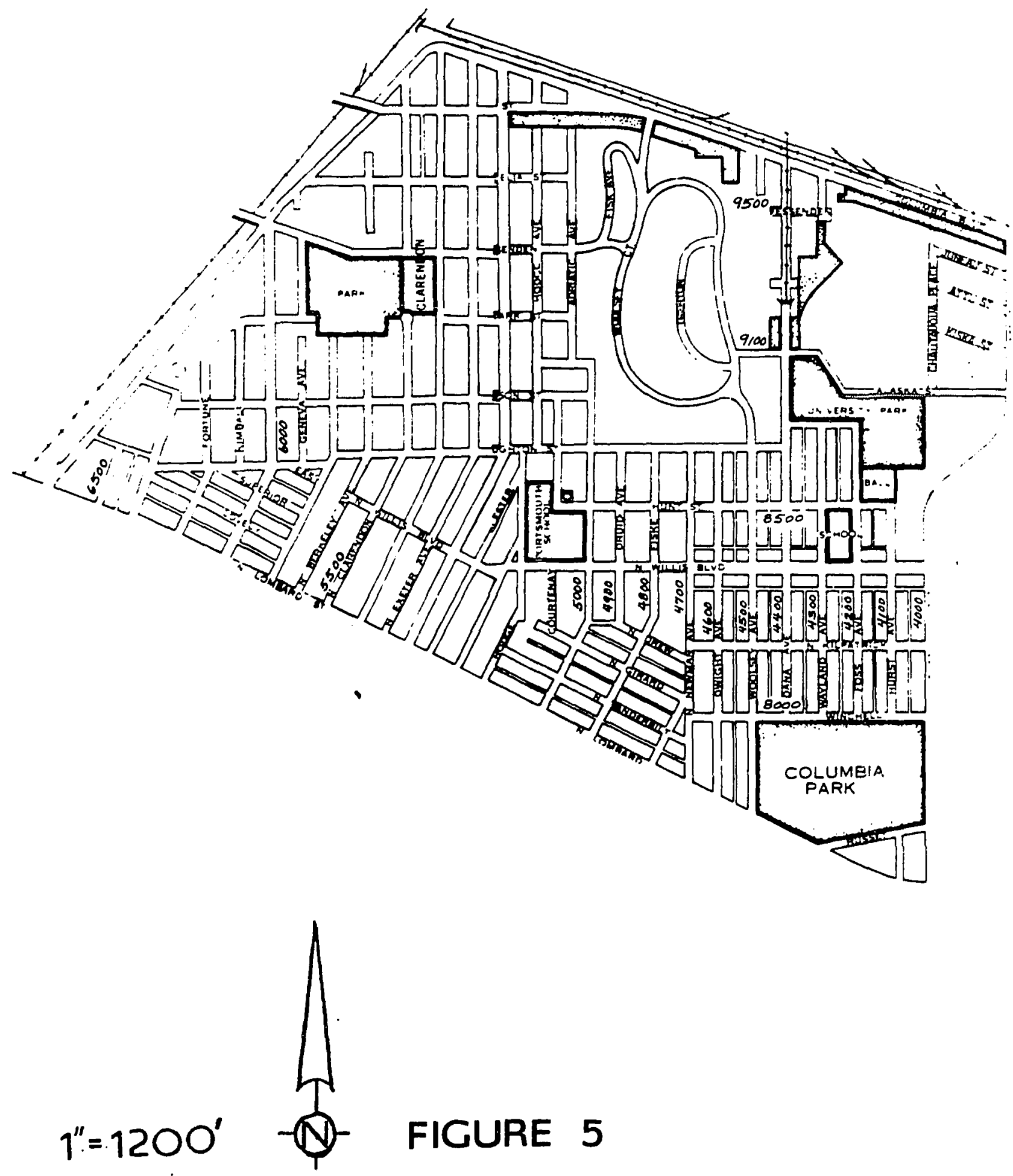


\section{BOUNDARY MAP \\ RICHMOND \\ (HDC)}

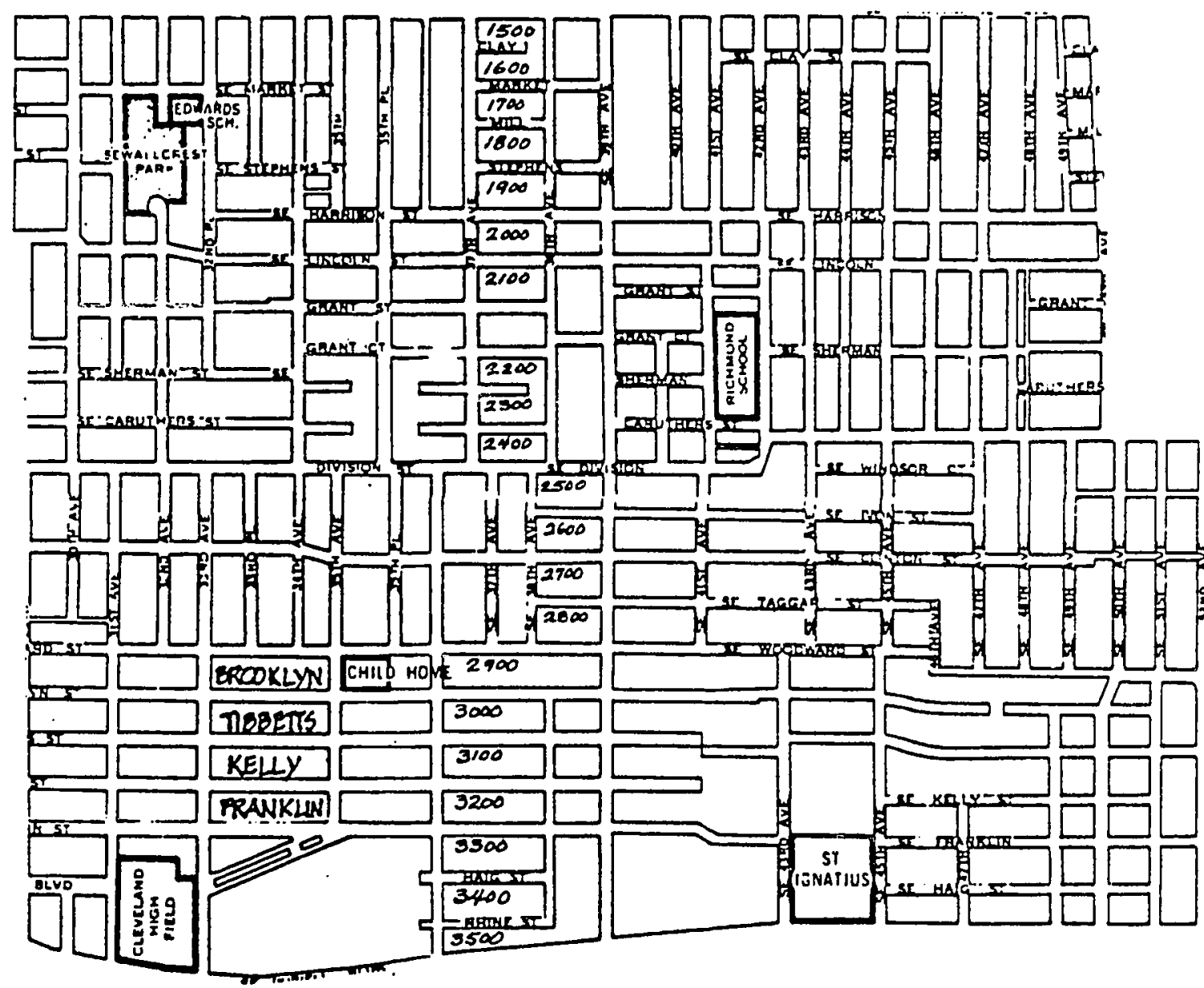

$1^{\prime \prime}=1200^{\prime}$ 


\section{BOUNDARY MAP CRESTTON}

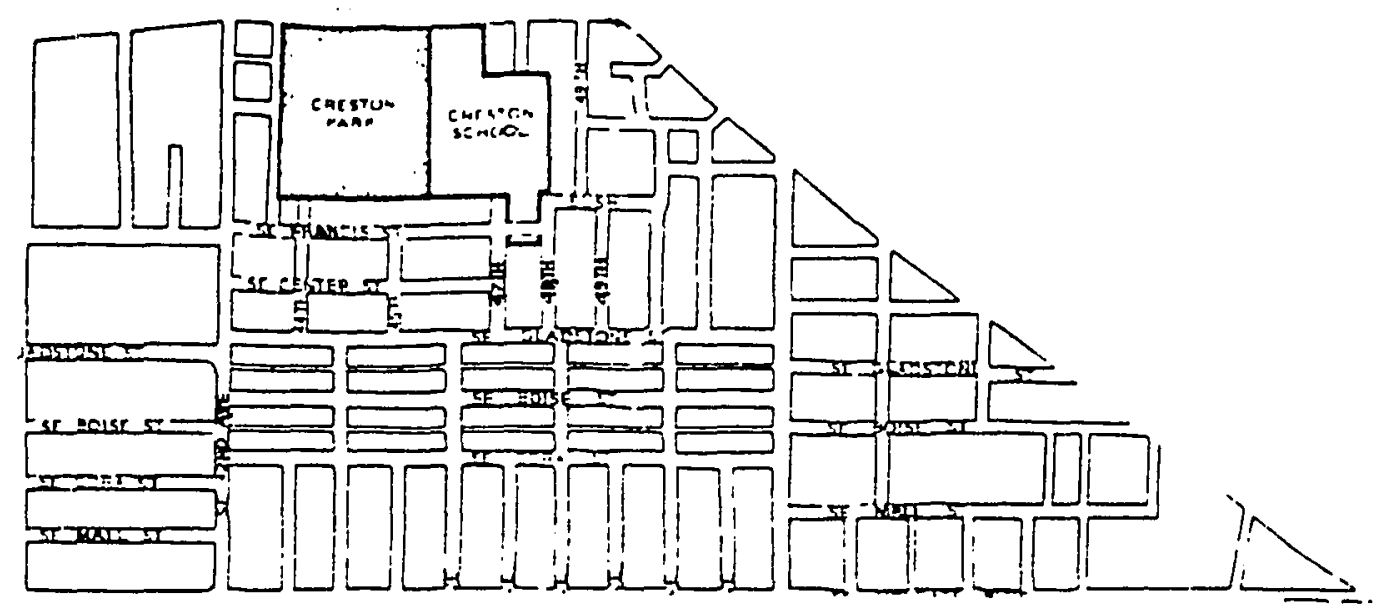

$1^{\prime \prime}=1200^{\prime}$ 
TABLE $X$

SOCIO-ECONOMIC CHARACTERISTICS OF COMPARISON NEIGHBORHOODS 1970

Median family income

\section{\& Minorities}

8 Over 65

\& Under 18

\section{Education}

88 years or less

$\& 1$ year or more of college

\begin{tabular}{|c|c|c|c|}
\hline $\begin{array}{l}\text { HCD } \\
\text { ST. JOHNS }\end{array}$ & PORTSMOUTH & $\begin{array}{c}\text { HCD } \\
\text { RTMND }\end{array}$ & CRESTON \\
\hline$\$ 8,250$ & 8,200 & 9,000 & 9,000 \\
\hline 18 & 68 & 18 & 18 \\
\hline 108 & 98 & 118 & 178 \\
\hline 338 & 408 & 278 & 268 \\
\hline 298 & 258 & $23 \%$ & 278 \\
\hline 158 & 188 & 158 & $18 \%$ \\
\hline
\end{tabular}

Source: City of Portland, Office of Planning and Development (1978). "Neighborhood Profiles of the City of Portland 1960-1970". 


\section{TABLE XI}

HOUSING CHARACTERISTICS OF COMPARISON NEIGHBORHOODS

1970

\begin{tabular}{|c|c|c|c|c|}
\hline & $\begin{array}{c}\text { ST. JOHNS } \\
\text { HCD }\end{array}$ & PORTSMOUTH & $\begin{array}{c}\text { RICHMOND } \\
\text { HCD }\end{array}$ & CRESTON \\
\hline Median Hsg. Value & $\$ 12,500$ & 12,500 & 12,500 & 13,250 \\
\hline \& Hsg. below $\$ 10,000$ & 328 & 278 & 238 & 208 \\
\hline Ratio owner: renter & $1,5: 1$ & $.75: 1$ & $1: 1$ & $1: 1$ \\
\hline \# Households & 4171 & 1542 & 8488 & 1757 \\
\hline
\end{tabular}

Source: City of Portland, Office of Planning and Development (1978). "Neighborhood Profiles of the City of Portland 1960-1970" and "Housing Market Analysis and Data Summary for the City of Portland". 
HCD neighborhoods that could have been selected for this study, St. Johns and Richmond were chosen for two reasons. First, as demonstrated by the Tables above, they were two neighborhoods which shared boundaries with comparable non-HCD neighborhoods. Even though HCD neighborhood populations were larger than the control neighborhoods, a windshield survey, covering every street in each nelghborhood, showed the types and sizes of housing, lot sizes, neighborhood facilities and neighborhood layout to be similar. Second, Housing and Community Development activities marked the first significant government funded improvement efforts in both neighborhoods.

A two-step process was used to develop random samples for the neighborhoods. First, maps showing each building in the four neighborhoods were obtained from the Bureau of Streets and Structural Engineering. A windshield survey of each neighborhood made it possible to designate commercial and industrial buildinzs on the maps. Housing units were each given identification numbers. For the two comparison neighborhoods, Portsmouth (non-HCD) and Creston (non-HCD), 100 identification numbers were selected from a random number table to determine the households to be surveyed. In Richmond (HCD) and St. Johns (HCD), the program neighborhoods, fifty homes were randomly selected in the same fashion. For comparison purposes, fifty households in each HCD neighborhood were also chosen randomly from a list of known loan recipients to make certain that a sufficient number of loan reciplents were included in the survey for statistical results to be neaningful. Sets of alternative households were chosen in the same way. Where a resident refused to participate in the survey or was unavailable after repeated attempts, the alternative housing unit closest to that person's home was used in an effort to control for 
any sample bias which might stem from the refusals.

Prior to conducting the interview, a letter of introduction and

intent was sent to each study household, explaining the purpose of the study and asking for their cooperation. An example of the letter is included in the Appendix. Each sample home was visited up to a total of three times, after which telephoning was tried up to four additional times. Interviews were completed with $87 \%$ of the original designated households; only $13 \%$ of the alternative homes needed to be used.

The 400 persors sampled were asked to provide data capable of indicating both urban decline as shown in Table XII as well as their attitudes toward their homes, neighbors, and neighborhood:

1. Demographic information, sex, age, race, household size, marital status, years of school and income.

2. Loan-related information, renter/owner, length of residence in the neighborhood, reasons for movirig into nelghborhood, whether reciplent of loan, loan type, satisfaction level related to loan, home improvements made with loan, other improvements made, reasons for improvements, means of financing other than loan.

3. Housing and neighborhood conditions, ratings of specific housing characteristics such as plumbing and heating, whether the neighborhood has changed over the last few years, how it has changed, rating the condition of streets, sidewalks, street lights, etc., and improvements needed in the neighborhood.

4. Sense of community whether a person intends to stay in the neighborhood, reason for moving, area of new residence, satisfaction with neighbors.

Questionnaire items were mostly designed to be close-ended. These questions were pre-coded, while open-ended questions were coded by a single person to ensure consistency. A copy of the questionnaire is 
TABLE XII

INDICATORS OF URBAN DECLINE OR STABILITY

Variable

Soc1o-economic Status

Income

Education

Occupation

Demographics

Household Age

Household Size

School Enrollment

Racial-Ethnic Minorities

Racial Groups

Structure Characteristics

Omer Occupancy

Unit Value
Concept

A neighborhood's change in the specific variable in relation to change in the city as a whole serves to identify the evacuation of an area by the more affluent populations and the in-migration of poorer groups.

Changing age characteristeristics indicate invasions of young family-raising groups and evacuation of older foreign-born households. Increasing stress is therefore placed on neighborhood infrastructure.

This variable reveals the path of diffusion of ghetto concentrations or the vacation of a neighborthood by white sub-populations.

A high degree of owmer occupancy may indicate a potential for a high degree of maintenance; declining occupancy rates may signal impending decline. Unit values can elther indicate persistence or change.

Source: Hughes, James (1975). Urban Homesteading. New Brunswick, N.J.: Rutgers University. p. 54. 
included in the Appendix.

To discover whether people are arare of the effects of the loan prograns, residents were simply asked in the neighborhood survey whether or not they had noticed any improvements going on in their neighborhood, and if so, what kind. Then, to test for changes in people's attitudes toward their neighborhoods as a consequence of the government programs, persons living in both HCD and non-HCD districts were asked to rate their neighborhoods as places to live. Four choices were given 1 =very good, 2=good enough, 3-not so good, and 4not good at all. HCD neighborhood people should have significantly lower scores than non-HCD neighborhood respondents if perceptions of their neighborhood have inproved since the start of the program. Asked about the condition of the houses in their neighborhoods, they should show the same differences.

At the same time, more $H C D$ area people should have responded "getting botter" when asked if their neighborhood was getting better, staylng the same, or getting worse. Finally, when asked the question, "All things considered, how satisfied or dissatisfled are you with this neighborhood as a place to I1ve, 1=completely satisfied, 2=mostly sat1sfied, 3-neutral, 4mostly dissatisfied, 5-completely dissatisfied", the HCD neighborhoods should have shown significantly lower scores than non-HCD area people. Such information helps to isolate HCD effects on neighborhood residents.

Sinilar questions were asked about three other publicly provided services to the nelghborhoods : police protection, street lighting, and street repair, as there is a very strong relationship between the level of city services and evaluation of neighborhood quality (Iovrich, 1976. 208, Anton and Bowan, 1976,11-12). Dissatisfaction with such services 
could have a negative impact on neighborhood satisfaction which could, in effect, counteract positive reactions to HCD-funded improvements. In all, a total of 72 variables were used for this part of the study.

The chapter that follows reports recipient evaluations of Portland's loan process. From there, the impact of the loan program is studied. First, loan reciplents are defined according to their social and economic characteristics. Their homes are categorized according to age and value. Next, findings from the neighborhood survey which apply to the impact of the program on the neighborhoods themselves are covered in Chapters VIII through XI.

\section{Footnotes for Chapter V}

1. Estimated number of households for the four neighborhoods for 1970 were St. Johns, 4171; Portsmouth, 1542; Rlchmond, 8488; Creston, 1757 (Portland, Oregon, Office of Flanning and Development 1978, 37-105). Estimated number of households receiving loans in each neighborhood was one in every ten single family homes. 
CHAPTER VI

\section{AN EVALUATION OF THE LOAN PROCESS}

Recall that a successful rehabilitation program includes five necessary elements. First, areas where rehabilitation is to take place need to be carefully selected. Portland's Office of Policy Development produced a complicated process, described in Chapter IV, to ensure that neighborhoods were selected for the loan program which could most benefit from the program. Care was taken so that neighborhoods facing too serious a decline were not selected, nor were nelghborhoods which were "stable". The second action needed is to make certain that affected residents are appropriately prepared. The Portland Development Commission marketed the loan program door-to-door in Housing and Community Development neighborhoods so that each homeowner had an opportunity to ask questions about the prograns as well as receive literature about applying for a loan.

The third factor needed is an examination of economic and social characteristics bearing on the feasibility of rehabilitation. In addition to taking special care that neighborhoods selected for the loan program

are those which only show the first signs of decay, Developrent Commission counselors are careful to match the type of loan with the income and assets of potential loan recipients.

The fourth factor, establishing reasonable and specific physical rehabilitation standards, meant that priority was given to meeting city housing code requirements but that additional loan money could be used 
as the loan reciplent chose. Finally, Portland's loan process provided a means of financing and assistance which included counseling, work writeups, and assistance in applying for financing.

Yet, even though the basic criteria for a successful process was met by the city, ultimately evaluations by recipients of the loans best communicate whether there are any gaps in the process which need to be addressed. As reported earlier, the first step taken to learn how the recipients rated the loan process itself was to study the internal files of the Portland Development Commission. In those, recipients rated the services of the Development Commission and their contractors and reported whether they felt the programs were worth recommending to their neighbors. Although only a little over a hundred porsons filled out evaluation sheets in the sample of recipient files surveyed, all but tho rated the program as good to excellent, suggesting that loan recipients were comfortable with the loan process. To verify their evaluations, fifteen questions were inciuded in the nelghborhood survey described below which asked recipients to rate the program, the Commission's services, the work done, and whether or not they would recommend the program to others. (The full questionnalre is included in the Appendix.)

\section{RECIPIENT EVALUATIONS}

For the most part, evaluations recorded durlng the course of the neighborhood survey were even more positive than those received by the Portland Development Comission staff. Recipients were enthusiastic about the loan program process, the Development Commission staff, and usually the contractors. Approximately two-thirds of all the homeowmers interviewed in the survey were loan recipients, Of the recipients, most 
received DPL loans $(H=34)$. In St. Johns, another eleven received 312 loans, seven received PII loans, and four, HCD-3 loans, In comparison, more Richmond recipients received HCD-3 loans (11) while fourteen people were equally divided into 312 and PIL Ioan recipients.

Reflecting the difference in the types of loans received, Richnond recipients tended to borrow more money for their homes. Whereas almost $60 \%$ of the St. Johns recipients recelved $\$ 4,000$ or less, in Richmond $41 \%$ received that much, $60 \%$ received $\$ 5,000$ or more.

In response to the question, "In general, do you think the loan program is very good, good enough, not so good, or no good at all?", $79 \%$ of St. Johns and $85 \%$ in Richmond responded very good. Another $12 \%$ In Richmond and $17 \%$ in St. Johns answered good enough. Only three people felt that the program was not so good. All three later complained of problems with their contractors. Nobody rated the program as "no good at alI". It is interesting to note that larger loans did not affect the ranking. Even though St. Johns: inhabitants tended to receive smaller loans, they were more satisfled with the program.

FDC itself was rated very highly, as well. When asked to rate the services of the agency during the processing of the loan, over three-quarters of St. Johns respondents ranked PDC as excellent. Nine percent answered "good". In Rlchmond, again, a solld majority rated PDC excellent (66\%), while another $24 \%$ felt the processing was good. Hhereas approxImately the same proportion of poople ranked PDC falrly highly in both neighborhoods, St. Johns showed a much higher proportion of "excellent" ratings. Only nine people in all ranked PDC poorly.

Feople were less satisfled with the work done on their homes. Although half of St. Johns and almost half of Richnond rated the 
rehabilitation work as excellent, many of these people did the work themselves. Almost a fifth (17\%) of St. Johns loan recipients rated their rork as poor. In Richmond, 12 percent did.

Those who rated the contractors poorly frequently expressed

outrage. Several comments found in the Comnission's in-house evaluation follow here:

The above mentioned contrector should be banished to charm school and leam how to make friends and influence people--also the concepts of employer and employee relations. (Threats and browbeats not accepted.)

Mr. $X$ and helper ok, but Firm $A$, Firm $B$ and Firm $C$, I would not recommend to $\mathrm{IIx}$ a dog house.

I am sormy to say I would not recommend Firm $E$ to anyone. I rate them very poor in every way.

Cornparable remarks were made during the course of this survey. Complaints tended to be of three types, that the contractors underestimated the amount of time or money needed for the job, that the work done was slipshod, or that the contractors were irresponsible.

Becipients tended to disagree on whether or not the loans received were sufficient to pay for all the rork planned, both in the FDC evaluations and in this study. In St. Johns, slightly less than half felt that their loan was sufficient. In contrast, $61 \%$ felt their loan was enough in Richmond. St. Johns dissatisfaction may be related to loan amounts. It seems reasonable that since the recipients tended to make the same kinds of improvements, Richmond's people, receiving a larger loan on the average, would be more satisfied. Along the same vein, more people in St. Johns (58\%) ended up using additional money of their own to make home improvements than was true in Richmond (44\%).

St. Johns reciplents seem to rely more heavily on program funding 
than did Richmond's. Sixty-five percent of the St. Johns recipients felt that if they hadn't received a loan, they would have never been able to make Inprovements. The same was true for only $44 \%$ of Richrond's recipients. So although the loan program was highly rated in Richmond, many are likely to have worked on their homes without the loan, though most people admitted that it probably would have taken much longer.

\section{CHAPTER SUMMARY}

Even with some reservations about the work done and whether or not the loan was sufficient to do the work planned, $98 \%$ of its recipients would recommend the program. In fact, during the course of this survey, when people were asked if they would recommend the program, respondents invariably said not only that they would but that they had, usually pointing to the homes of neighbors to whom they had spoken about PDC. In St. Johns, people made it a point to tell the interviewer that not only had they told their neighbors, but their relatives as well--surely reflecting a highest form of satisfaction with the loan process. The only two people who would not recommend the program had serious problems with their contractors.

\section{Footnotes for Chapter VI}

1. It should be mentioned that in this survey, to evaluate the loan process, respondents were given four choices instead of three I "very good, good enough, not so good, not good". Ratings for the contractors and the Development Commission were measured in the same manner as the in-house evaluations. 
CHLPTER VII

IMPACT EVALUATION

CRITERIA\& WHO BENEFITS?

INTRODUCTION

The first step in evaluating the impact of any program is to answer the question, "Who benefits?". Before the neighborhood survey was undertaken to discover the impact of the loan programs on the neighborhoods where they have been funneled, It was first necessary to explore the characteristics of the loan recipients themselves. Although the Housing and Community Development Act stipulated that programs funded by that act should go to low and moderate income people, the characteristic "low or moderate income" cannot in and of itself define the recipients of the loan programs. To gain a clearer understanding of just who those recipients have been, as well as what types of homes are benefiting from the loans, a random sample survey of $15 \%$ of the Portland Development Commission's internal files was taken in the summer of 1978. Characteristics studied included socio-economic characteristics of the recipients such as age, sex, marital status, and income, plus pertinent information related to their homes such as housing costs per month, assessed value, and rehabilitation work done.

\section{SOCIO-ECONOMIC CHARACTERISTICS}

Analysis of loan recipient files showed Portland's subsidized loan 
programs serving people who can meet day-to-day living costs yet are not able to maintain their homes. Most loan recipients have been women, almost half of whom were divorced. Over a third of the women receiving loans were widows and $9 \%$ were single. Of the men who received rehabilitation loans for their homes, only $4 \%$ were divorced, $1 \%$ widowers, and $6 \%$ single, leaving almost $90 \%$ married. Taking both sexes together, married couples far outweighed persons of other marital types by at least two to one.

\section{TABLE XIII}

MARITAL STATUS OF LOAN RECIPIENTS

Marital Status

Sex

\begin{tabular}{|c|c|c|c|c|c|c|}
\hline & & le & $\mathrm{Fe}$ & ale & & \\
\hline & $\mathrm{N}$ & $\%$ & $\mathrm{~N}$ & $\%$ & $N$ & $\%$ \\
\hline Single & 9 & 6.2 & 10 & 9 & 19 & 7.4 \\
\hline Married & $127^{*}$ & 87 & 5 & 4.5 & 132 & 51.4 \\
\hline Divorced & 6 & 4.1 & 54 & 48.6 & 60 & 23.3 \\
\hline Hidowed & 2 & 1.4 & 38 & 34.2 & 40 & 15.6 \\
\hline Total & 144 & & 107 & & & \\
\hline
\end{tabular}

As for age, few recipients were very young. Instead, $97 \%$ of the loan recipients fell between 24 and 68 years with a median age of 43. At the same time, the loans did tend to be slightly skewed toward younger people. Almost half of the recipients were under 40 years of age (see Table XIV). 
TABLE XIV

IOAN RECIPIENT AGES

\begin{tabular}{ll|l} 
Age Categortes & N & $\%$ \\
\hline $20-30$ & 53 & 20 \\
$30-40$ & 70 & 26 \\
$40-50$ & 39 & 15 \\
$50-60$ & 38 & 14 \\
Over 60 & 65 & 25 \\
\hline Totals & 265 & 100
\end{tabular}

When men and women were compared by age, the female recipients tended to be older. Almost half of the women receiving loans were over 50 years old (Table XV).

TABLE XV

$$
\begin{aligned}
& \text { COMPARISON OF LOAN RECIPIENT AGES, } \\
& \text { MALE AND FEMAIE }
\end{aligned}
$$

\begin{tabular}{ll|ll|l} 
Ase Categories & $N$ & \% Male & N & \% Female \\
\hline $20-30$ & 40 & 27 & 13 & 11 \\
$30-40$ & 39 & 26 & 31 & 27 \\
$40-50$ & 22 & 15 & 17 & 15 \\
$50-60$ & 16 & 11 & 22 & 19 \\
Over 60 & 32 & 21 & 33 & 28 \\
\hline Totals $N=266$ & 149 & & 116 &
\end{tabular}

Three-fourths of the loan recipients were white. 1 . This was true for both men and women. Marital status did not differ significantly by race. Comparing races across loan amounts, blacks tended to get larger loans. Only $13 \%$ of the blacks recelved loans of under $\$ 2,500$ while $20 \%$ of the 
white recipients did. For both races, half of the loans received were between $\$ 2,500$ and $\$ 5,000$. Finally, $12 \%$ of white and $14 \%$ of blacks received loans over $\$ 10,000$ (see Table XVI).

TABLE XVI

LOAN AMOUNT BY RACE

Ioan Amount

Race

\begin{tabular}{|c|c|c|c|c|c|}
\hline & \multicolumn{2}{|c|}{ Black } & \multicolumn{2}{|c|}{ White } & Total \\
\hline Under $\$ 2,500$ & 8 & 13 & 40 & 20 & 48 \\
\hline$\$ 2,501-\$ 5,000$ & 33 & 50 & 89 & 50 & 122 \\
\hline$\$ 5,001-\$ 10,000$ & 13 & 23 & 43 & 18 & 56 \\
\hline Over $\$ 10,000$ & 9 & 14 & 24 & 12 & 33 \\
\hline Total $N=262$ & 63 & 100 & 196 & 100 & 259 \\
\hline
\end{tabular}

Mean Loan Amount: $\$ 5,465$

Household sizes tended to be small, with almost half of the reciplents living in a house with two or fewer people. Only $12 \%$ of all recipients had households of over four persons.

For the purposes of this study, the sample was distributed among eight occupational categories: professional, clerical and sales, service occupations, processing occupations, machine trades, bench work, structural, and miscellaneous. The last category included people receiving welfare, unemployment, soclal security, or pension benefits. Four occupajion categories comprised the bulk of the total sample. In the miscellaneous category, which accounted for $51 \%$ of the recipients, $14 \%$ of the recipients were receiving welfare or unemployment payments while almost $30 \%$ were on social security or a pension system. Table XVII shows 
the professional, clerical, and service occupations to be the other three significant categorles.

TABLE XVII

LOAN RECIPIENT OCCUPATIONS

\begin{tabular}{lcc} 
Occupation Type & $\%$ & $N=247$ \\
\hline Professional & 13 \\
Gerical and Sales & 11 \\
Service Occupations & 13 \\
Processing Occupations & 1 \\
Machine Trades & 3 \\
Bench Work & 5 \\
Structural & 4 \\
Miscellaneous & $51 *$ \\
* Includes 14\% welfare or unemployment and \\
30\% on social security or pension.
\end{tabular}

Monthly incomes for the reciplents were low. Over a third of the recipients had incomes under $\$ 500$ per month. Almost three-fourths had incomes under a thousand dollars (Table XVIII).

TABLE XVIII

IOAN RECIPIENT INCONE FER MONTH

\begin{tabular}{|c|c|c|}
\hline Income Categories & N & $\%$ \\
\hline Under $\$ 500$ & 95 & 36 \\
\hline$\$ 501-\$ 1,000$ & 90 & 35 \\
\hline$\$ 1,001-\$ 1,500$ & 52 & 20 \\
\hline Over $\$ 1,501$ & 23 & 9 \\
\hline Total & 260 & 100 \\
\hline
\end{tabular}

Mean : $\$ 755.70$

As Table XIX shows, women recelving loans tended to have lower incomes than men. Over half of the women recelving loans eamed less 
than $\$ 500$ per month while only $20 \%$ of the men did. About a thind of both sexes earned \$500-\$1,000 per month. Although aimost half of the men earned more than $\$ 1,000$ per month, less than $10 \%$ of the women did.

TABLE XIX

MONTHLY INCONE BY SEX

Income Categories

\begin{tabular}{c:cr}
\multicolumn{2}{c}{ Sex } & \\
Male & Female & \\
20 & 58 & \\
35 & 34 & \\
29 & 8 & \\
& &
\end{tabular}

Over $\$ 1.501$

Hean

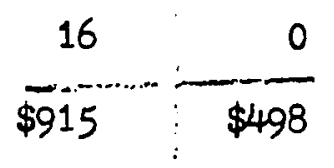

Loan recipients were people who, for one reason or another, had not been able to accumulate any savings for home improvement projects. Many, particularly the elderly, were on fixed incomes. For those who were not, raisine children took up any extra funds that might otherwise have been saved. Over half of the loan recipients had no savings at all. Altocether, 66\% of the recipients had savings of under $\$ 500$. A further $23 \%$ had less than $\$ 3,000$, leaving only $11 \%$ with savings over $\$ 3,001$, as shown in Table XX:

TABLE XX

LOAN RECIPIENT SAVINGS

\begin{tabular}{lr|rr} 
Savings Categories & $N$ & $\ldots$ & \\
\hline$\$ 0$ & 143 & 55 & \\
$\$ 1-\$ 500$ & 29 & 11 & $N=260$ \\
$\$ 501-\$ 3,000$ & 59 & 23 & \\
Over $\$ 3,001$ & 29 & 11 &
\end{tabular}


The only group having any significant savings was the uidow(er)s, of that group almost a third had over $\$ 3,000$.

Housing costs were low for reclpients, suggesting that although they could not afford rehabilitation work without some subsidy, once the work was completed, they would probably be able to remain in their homes, barring any substantial increase in property taxes. Housing costs ranged from a low of $\$ 67$ to a high of $\$ 1,217$ per month, with a median cost of just over $\$ 200$. Iess than $3 \%$ of the recipients needed over $\$ 400$ a month to keep up their morigage payments and pay for utilities. In fact, $44 \%$ needed less than $\$ 200$ per month (Table XXI). This was largely due to the number of elderly recipients who owed no balance on their mortgages.

TABLE XXI

\begin{tabular}{lcc} 
MORTG AGE AND UTIIITY COSTS,$~$ & \multicolumn{2}{c}{ LOAN RECIPIENT } \\
Housing Costs Per Month & $N$ & $\%$ \\
\hline$\$ 0-\$ 100$ & 12 & 5 \\
$\$ 101-\$ 200$ & 101 & 39 \\
$\$ 201-\$ 300$ & 99 & 38 \\
$\$ 301-\$ 400$ & 41 & 15 \\
Over $\$ 401$ & 8 & 3 \\
\hline Totals & 261 & 100
\end{tabular}

HOUSING CHARACTERISTICS

The majority of homes rehabilitated through the loan programs were well over fifty years old, with the average house being built. In 1924. Less than a quarter of the homes renovated were built after 1935. Only 7\% of the houses were under 20 years old, the most recent bullt in 1973. 
Reciplent homes had from one to seven bedrooms, averaging three. The average house measured 1,179 square feet. When purchased, their prices ranged up to $\$ 31,500$ with a midale cost of $\$ 12,400$. Feople acquired their homes anywhere from 1922 to 1977 . The median purchase year of 1971, however, euggests that most people have purchased their homes in the last eight years. Assessments for the homes varied from $\$ 5,400$ to $\$ 36,190$, with a mean of $\$ 16,837$. Only $9 \%$ were valued at over $\$ 25,000$ (Table XXII).

TABIE XXII

ASSESSED VALUES, RECIPIENT HOMES

\begin{tabular}{lc:c} 
Value Categories & $\mathrm{N}$ & $\%$ \\
$\$ 0-\$ 10,000$ & 31 & 12 \\
$\$ 10,000-\$ 15,000$ & 73 & 28 \\
$\$ 15,001-\$ 2,000$ & 85 & 32 \\
$\$ 20,001-\$ 25,000$ & 51 & 19 \\
Over $\$ 25,001$ & 23 & $\vdots$ \\
\hdashline Total & 263 & 100
\end{tabular}

Only about 60 of the recipient files supplied an estimated value for their homes follouing rehabilitation. This number is too small to give anything but a vague indication of value increases. Nonetheless, the data suggests that the loans gain high benefits for their costs. Where the average loan was $\$ 5,465$ (median, $\$ 4,000$ ), the average increase In value expected was $\$ 8,460$ (median: $\$ 10,000$ ), almost two times the dollar amount put into the house.2 


\section{A LOOK ACROSS LOAN TYPES}

DPL

Some differences in the characteristics of the recipients can be seen when they are separated by the type of loan received. Feople receiving Deferred Payment Ioans tended to be older than recipients of the other three loans, with an average age of 53 years. A third of the DPL recipients were married, a thind divorced, and a quarter, widowed. Three quarters were white. More females received DPIs than men by a ratio of three to two. Households tended to be small, usually having two people. Monthly incomes were low, averaging less than $\$ 500$. A full three-fourths of the group were on welfare, unemployment insurance, or social security. At the same time, housing costs per month were low. Ranging from $\$ 67$ to $\$ 467$, they averaged $\$ 206$. Though people owed anywhere up to $\$ 21,836$ on their homes, most owed under $\$ 6,000$ (mean: $\$ 4,818$ ).

The houses owned by DPL recipients were old. Most were built before 1920. While assessment values went from a low of $\$ 5,400$ to a high of $\$ 36,190$, they tended to cluster around $\$ 15,000-\$ 20,000$.

$\underline{\mathrm{HCD}}$

Even though people could receive up to $\$ 17,400$, the average HCD loan was $\$ 10,500$. People receiving HCD loans tended to be younger than those receiving DPIs. In age, they ranged from 25 to 66 with an average age of 39, over 10 years younger than the typical DPL recipient. Fewer people recelving HCDs were divorced when compared to DPL recipients (64\% married, 18\% divorced). Household sizes tended to be larger, four people on the average, usually due to the presence of two dependents. anly $18 \%$ were on welfare, social security or unemployment insurance. 
Monthly incomes were much higher than for recipients of DiIs. In fact, they were over twice as large (average: \$970/month; median: \$1,105). Housing costs also ran about $\$ 40$ higher (range: $\$ 122-\$ 362$, mean: $\$ 242$ ). Few people had sizable assets. Ninety-one percent had under $\$ 500$.

HCD homes also tended to be older than DPL houses, suggesting the need for more rehabilitation work. Host were older than 60 years. Recipients, however, had purchased their homes fairly recently (average 1969 versus 1963 for DPLs) which ras reflected in their mortgage belances (average $\$ 10,650$ versus $\$ 5,818$ for DPLs). Assessed valuations put HCD homes at the same level as DPIs.

312

Though larger in dollar anount than DPIs, 312 loans were not as large as HCDs (mean $\$ 7,401$ ). Socio-economically, recipients of 312 loans tended to be much like the reclplents described above. They ranged in age from 21 to 69 with an average age of 39. Most were married (73\%). Most were white (72\%). Kouseholds usually had three people. Although more people (24\%) recelving these loans were on welfare, social security. or unemployment than HCDs, they were a smaller proportion than present with the first loans described. The mean monthly income was $\$ 1,141$. Assets also tended to be higher (median $\$ 440$ ) than for reciplents of the other two loans. Still, housing costs were only more per month than those faced by HCD recipients (mean : \$262; range \& \$90-\$1,210).

As with the other two loans, most houses had three bedrooms. Iike DPIs, 312 homes were a little over 50 years old on the average. Iike HCD's, people had typically only ouned thelr homes since 1969, leaving a high mean mortgage balance $(\$ 11,182)$. Finally, assessed values were close to both HCDs and DPIs, averaging $\$ 16,425$. 
PIL

Public Interest Ioans were not as high as HCD loans but higher on the average then DPL and 312 loans, with a mean of $\$ 9,367$. As with HCDs and 312s, PII recipients were young (average age 8 38). No one over 60 recelved one of these loans. PIL loans tended to go to couples showIng the highest soc10-economic class when compared to the other loans. By far the bulk of PII loan recipients were married (88\%). Few divorced individuals and no widow(er)s received this type of loan. Eighty-eight percent were white. Household sizes averaged four, largely because most of the married couples receiving loans had two chlldren. Few people (13\%) were living on government subsidies. Monthly incomes were the highest of all the categories. Punning from $\$ 70 ?$ to $\$ 1,921$, they averaged $\$ 1,379$ (median $\$ 1,478$ ). On the other hand, few people had assets of over $\$ 1,000$. Housing costs were less than the 312 s but larger than the other two loan types. Feople paid out from $\$ 154$ to $\$ 408$ with an average of $\$ 256$.

Houses here usually had three bedrooms and were newer than the houses for any of the other loans. Built between 1904 and 1973, the average house was under 40 years old in 1975. On the whole, the homes had also been purchased fairly recently. Most had been owned since 1967. Mortgage balances were in league with balances reflected in the 312 and HCD groups (mean: \$9,658). Finally, housing units receiving FII loans had higher assessed values than any of the other loans. Running from $\$ 14,050$ to $\$ 31,880$, they clustered around $\$ 20,500$.

\section{Loan Types: Cross Comparisons}

A number of variables were compared across all loan types to see 
If they differed significantly when recipients were divided into groups according to the type of loan received. Analysis of variance tests showed that monthly incomes and housing costs per month were significantIy different for the four loan types. Assets, on the other hand, did not differ significantly. Feople showed the same assets patterns, i.e., most had few assets, no matter which loan type was considered. The assessed values of homes were similar for all loan types. For all four loans, houses were assessed at about $\$ 16,500$ with over two thinds of the houses ranging from $\$ 10,000$ to $\$ 21,0003$.

Women roceived significantly smaller loans than men. Comparing loan amounts with marital status demonstrated that the higher the loan amount, the greater the possibility a married couple received the loan.

St, Johns and Southeast Portland

Ioan amounts for the St. Johns neighborhood ranged from $\$ 1,006$ to $\$ 18,391$ with an average loan of $\$ 5,405$. Most people in St. Johns received DPL loans, Over two-thirds of the loans, in fact, ranged between $\$ 2,000$ and $\$ 9,000$. Though loan reciplents were from 21 to 83 years old, the average age was fairly high at 49 years. Most persons were married (66\%) and there was a fairly high proportion of widow(er)s (22\%). Almost all of the reciplents were white (91\%). Household sizes tended to be small, clustering around two people per family. Monthly incomes $\operatorname{ran}$ from $\$ 130$ to $\$ 1,921$ per month with an average of $\$ 724$ (median : \$602). Over half the population had assets of less than $\$ 1,500$. Housing costs per month tended to be low in St. Johns. Going from a low of $\$ 71$ to a high of $\$ 405$, the mean cost was $\$ 189$. Houses were small, most having two to three bedrooms. They also tended to be 
fairly old. Though built between 1900 and 1973, most were at least 40 years old by 1975. Feople had owned their homes for a long time, one person had ouned her home since 19:35. Over half of the homes had been ormed for 15 years before they were 2rhabilitated. This length of tine was reflected in the low balance of mortgage payments faced by most recipients (range: $\$ 0-\$ 26,000$; mean $\$ \$ 5,753$ ). Finally, houses in St. Johns were assessed from $\$ 9,200$ to $\$ 30,220$ with an average value of $\$ 15,999$.

Southeast recipients also received more DPIs than any other loan. Loan amounts ranged from $\$ 917$ to $\$ 18,444$ with a mean of $\$ 6,207$, almost a thousand dollars more than north Portland. Like St. Johns, people had an average of 46 years, with the youngest person 24 and the oldest 91. Almost half the recipients were married (47\%) while a fourth were divorced and 18\%, widow(er)s. Almost all of the recipients were white (96\%). Households usually had three members, with one child. Monthly incomes for the area as a whole were less than St. Johns, With a low of $\$ 171$ and a high of $\$ 1,573$, they averaged $\$ 720$ (median: $\$ 742$ ). Assets, on the other hand, were higher (mean: $\$ 3,319$ ). Housing costs per month were fairly high, averaging $\$ 252$ (range, $\$ 89-\$ 1,210$ ).

Most houses were over 60 years old in 1975. Purchase prices only averaged $\$ 13,285$, and most recipients had owned their homes for ten years when they received their loans. Consequently, mortgage balances recorded for the Southeast tended to be small, averaging $\$ 8,743$. Assessed values, on the other hand, had a tendency to be high, with a mean of $\$ 18,454$. 
CHAPTER SUMMARY

This chapter reported a median income for all loan reciplents of $\$ 600$ per month, half of the median monthly income of all Portland residents. Most loans went to citizens who earned between $\$ 230$ and $\$ 630$, with over half of the females receiving loans earning under $\$ 500$ per month. Assets for the loan recipients are few. Over three-fourths of the loan recipients had less than $\$ 1,000$ in savings. A full $55 \%$ had no savings at all. A total of $30 \%$ of the loan recipients were on social security or a pension; $21 \%$ on welfare or unemployment. $37 \%$ had professional clerical or sales, or service occupations. In aze, loan recipients ranged from 21 to 91 , with $87 \%$ between 24 and 68 . Loans were fairly evenly distributed over this are group. Women who received loans tended to be older. Over half the female loan recipients were over 50, where only a third of the men were. Recipients of the no-interest DPL loans were older than the recipients of the other three loan types.

Half of the loans went to married couples. The next largest number of loans went to divorced women. $16 \%$ went to widow(er)s. The number of persons living in a household that recelved a loan was usually three or less.

As for the houses owned by the loan recipients, the majority of the homes rehabilitated were over 50 years old, with a median assessed value of $\$ 16,500$. Housing related costs centered at a little over $\$ 200$ per month. Looking across loan types, recipients of DFL loans tended to be older with small households. Recipients of HCD and Section 312 loans tended to be younger and married. These loan recipients were generally employed, with a median income of about a thousand dollars a month. 
Recipients of PIL loans tended to be younger than DPL recipients, and 87\% were married. The houses for which PIL loans were given tended to be newer and to have higher assessed values than for the other three loan types. Women tended to receive lower interest loans than men. Finally, looking across the two HCD study areas, St. Johns and Southeast Portland loan recipients were similar in their soclo-economic characteristics and in the type of houses they owned.

\section{Footnotes}

1. Other than Whites and Blacks, only one Indian, one Spanish American, and two Asian recipients were in the survey.

2. Portland Development Commission housing specialists with assessor certification estimated the increases in value.

3. The following analyses of variance were performed to see if there were significant differences according to loan types Monthly income: $N=263, F=125$ ( $\mathrm{sig}$. less than 000) Eta=.7, Housing costs/ month: $N=261, F=5.94$ (sig. Iess than .001) Eta=.25; Total Assets: $N=260, F=.44$ (non-sig.), $. . t a=.07$; Assessed Value: $N=263, F=2.29$ (non-siz.), Eta=.16. Analyzing differences in loan amounts according to sex: Ioan Amount: $\mathrm{N}=266, F=7.99$ (sig. at less than .000), Eta=.37. 


\section{CHAPTER VIII}

\section{IMPACT EVALUATION}

\section{CRITERIA: OUTSIDE PERGEPTIONS OF IMFACT}

Prior to analyzing the neighborhood survey results in terms of prosram impact, an effort was made to obtain some secondary data which could suggest how the programs have affected HCD neighborhoods. Anthony Downs, for one, has suggested that significant changes within a neighborhood will be reflected by actions undertaken by outside actors regarding the neighborhood (Downs, 1970 Hermann, 1979,40).

In this study, two types of information were focused on as capable of indicating outside perceptions of impact: lending records and real estate trends. Both kinds of Information are important for two reasons. First, the perceptions of improvements by outside actors would indicate that there would be a significant number of respondents within neighborhood perceiving the neighborhoods as improving, rating them better as a consequence. Second, the Portland Development Commission and the city's Office of Planning and Development developed long-term goals for Portland's Housing and Community Development activities which included actions of outside actors. Ghapter IV showed that one of the goals central to the neighborhood rehabilitation program was to initiate stabilizing activities which could later be taken up by private industry, in particular, the city's financial institutions.

Both the lending and realty institutions are essential components 
to any long-term revitalization efforts in urban neighborhoods. Their perceptions of program impact are important. With banking institutions, the availability of credit is central to ensuring long-range results for any revitalization project such as Portland's. Urban decline has long been held to be intimately linked to the availability of institutional mortsage credit. Where there is decline, conventional mortgaee and home improvement money tends to be scarce. Increases in those funds suggest that a district is inproving relative to its surrounding areas.

With real estate, the acquisition of a residence is a simultaneous purchase of a neighborhood with all its associated social and physical attributes as well as a geographic location and the resulting accessibility to employment, shopping, and recreation sites (Meadows and Call, 1978:297-308). Ferhaps the best overall indicator of outside perceptions of neighborhood change is the trend in residential real estate market prices, since the market price captures not only the characteristics of the physical unit but also the quality of the neighborhood environment (Ahlbrandt, 1976:339).

\section{METHODOLOGY NOTES}

Market values indicate the demand for housing in a particular area. An analysis of the market values in the four neighborhoods helps to indicate whether the neighborhoods are perceived by outside actors as improving, decaying, or staying the same. For data, market prices asked for all of the homes ${ }^{1}$ put up for sale in the four nelghborhoods in July of 1975, 1976, 1977, and 1978 were compared for differences. Because of the makeup of the data ${ }^{2}, F$ tests were used to discem differences in market values for the nelghborhoods. 
To discover the reactions of local lending institutions to neighboxhood HCD activities, home mortgage and home improvement loan activities for thirteen baniss and savings and loans institutions from 1976 through 1978 were studied. Although the time span used is shorter than one might wish for in an ideal situation (Campbell, 1970:110-126), the two sets of information taken together offer some basis for inferring the attitudes of outside actors toward the neighborhoods.

\section{MARKET VALUES}

Before considering market values for the four neighborhoods, it should be noted that housing values in Portland have skyrocketed in the past six years. Table XXIII offers some price trends with which to compare findings from this study. It shows average price increases of houses in the north, southeast, west, and entire metropolitan area from 1972 through 1978. A look at the table shows that neighborhoods in north Portland do not compare any more favorably with the rest of the city as a consequence of the Ioan programs. In 1974, the average price of a home In north Portland was almost $\$ 18,000$ less than the average home in Portland. In 1978, the difference in prices was $\$ 21,000$, almost three thousand dollars more. For southeast Portland, however, the average price of $\$ 23,000$ was $\$ 17,000$ less than Portland on the whole. In 1978, the difference had closed somewhat to $\$ 10,000$, hinting that changes may be going on in Richmond.

Namroking trends down to the neighborthood level, the market values of approximately seventy homes in the four neighborhoods were compared to discover whether homeowners selling their homes in Richmond (HCD) and St. Johns (HCD) have been putting their homes on the market for 
TABLE XXIII

HOUSING PRICE TRENDS, NORTH, SOUTHEAST

WEST SIDE, AND PORTLAND METROPOLITAN AREA

Year
1972
1973
1974
1976
.1977
1978

North

$\$ 15,040$

18,200

22,770

22,180

25,750

33,880

Southeast
$\$ 18,840$
20,220
23,030
28,770
30,220
44,360

Southeast

West Side

$\$ 28,910$

32,060

35,080

44,380

52,420

63,830
Portland Metro Area

$\$ 32,000$

36,000

40,000

49,000

54,600

60,600

Source: Real Estate Trends (1978) pp. 6-7. 
significantly higher prices since the inception of Housing and Community Development activities. Recall that several studies have suggested that housing market values vary systematically with respect to differentials in housing and community characteristics (Cates, 1969; Kain and Quigley, 1970; Pollakowski, 1973; Edel and Sclar, 1974; Straszheim, 1975; Meadows, 1976). One would expect that improvements in neighborhood characteristics taking place in St. Johns ( $\mathrm{HCD}$ and Richmond ( $\mathrm{HCD}$ ) would lead to higher market values. Average asking prices for homes in the four neighborhoods over a four-year period are listed in Table XXIV.

TABLE XXIV

AVERAGE MARKCT PRICE, STUDY NEIGHBORHOODS

\begin{tabular}{llrrrr} 
& & 1975 & 1976 & 1977 & 1978 \\
HCD & St. Johns & $\$ 20,529$ & $\$ 22,169$ & $\$ 27,644$ & $\$ 42,761$ \\
& Portsmouth & $\$ 20,175$ & $\$ 19,300$ & $\$ 31,483$ & $\$ 37,964$ \\
HCD & Richmond & $\$ 25,518$ & $\$ 26,924$ & $\$ 33,268$ & $\$ 44,842$ \\
& Creston & $\$ 23,922$ & $\$ 27,185$ & $\$ 34,392$ & $\$ 58,648$ \\
\multicolumn{4}{c}{ Source : Real Estate Trends (1978) } & &
\end{tabular}

It is interesting to note that market prices skyrocketed in the summer of 1978 for all of the neighborhoods, to a point where they were twice the amount (or more) of the average assessed values of the homes as shown in Table XXV. 
TABLE XXV

ASSESSED VALUES AND ASKING PRICES, STUDY NEIGKBORHOODS

Assessed Value: 1978 Asking Price: 1978

St. Johns (HCD)

$\$ 21.745$

$\$ 42,761$

Portsmouth

$\$ 22,988$

$\$ 37,964$.

Richnond (HCD)

$\$ 28,660$

$\$ 44,842$

Creston

$\$ 26,177$

$\$ 58,648$

Source: Real Estate Trends (1978)

F-tests showed only one significant difference when market prices were compared. Ironically, in 1978, homes in Creston were put on the market for a significantly higher price than Richmond ( $F=9.127$, sig=.003). There were no significant differences between St. Johns and Portsmouth. Changes in outside perceptions are not taking place such that sellers in HCD neighborhoods expect to ask significantly higher prices for their homes.

\section{FINANCIAL INSTITUTIONS}

Interviews with officers from eighteen of the major banking institutions in Portland suggested that most of the major banks and savings and loan institutions were aware of HCD activities and perceived HCD neighborhoods to be improving. As a consequence, most felt that their loan policies rould change so that increased mortgage and home inprovement activity would be seen in loan neighborhoods. As one vice president of the Benjamin Franklin Savings and Loan expressed 1t, "It's like a snowball effect. Once the govermment goes in, other (institutions) follow". (Menath, May, 1979). 
In reality, loan activities have not increased significantly in St. Johns (HCD) and RIChmond (HCD) when those neighborhoods are compared with Portsmouth and Creston, and even when they are compared with the Portland SMSA. Tables XXVI, XXVII, and XXVIII show that the lending Institutions were most active in 1977 for all parts of the city, decreasIng in 1978. For all areas except Portsmouth, the value of the loans increased steadily. Comparing the study nelghborhoods with the rest of the metropolitan area, on the whole Portlanders received mortgage loans half again as large as the southeast neighborhoods and twice as large as the northern neighborhoods. Home improvement activities in turn do not show any particular patterns. Although home improvement loans almost doubled in value for the city, no notable increases took place in the four neighborhoods. It should be noted for Fortsmouth, however, that the average value of the home improvement loans decreased, just as the home mortgage loans did. Taken togethex the three tables suggest that outside actors do not seem to have perceived changes in the HCD neighborhoods. They have not changed their own policles regarding those neighborhoods relative to the rest of the city. Banking activities are no greater in terms of financial amount loaned or quantity. Market prices have not increased significaritly compared to non-loan neighborhoods.

At the time of the neighborhood survey, the loan program had not made enough obvious improvements in the neighborhoods to attract private investments to carry on the rehabliltation efforts started by the city. The stability of the market prices has both negative and positive implications, on the one hand, market prices keep assessed values down, helping the homeowmers to hold on to their homes. an the other hand, with the city anticipating pulling out of those neighborhoods in the near 
TABLE XXVI

HOME MORTGAGE ACTIVITY SUMMARY, STUDY NEIGHBORHOODS

\begin{tabular}{llll} 
& 1976 & 1977 & 1978 \\
& $\mathrm{~N}$ (Average) & $\mathrm{N}$ (Average) & $\mathrm{N}$ (Average) \\
\cline { 2 - 2 } & $99(\$ 22.335)$ & $204(\$ 26,835)$ & $152(\$ 32,636)$ \\
Creston & $17(\$ 21,433)$ & $40(\$ 23,736)$ & $35(\$ 30,507)$ \\
St. Johns & $31(\$ 18,098)$ & $93(\$ 20,785)$ & $98(\$ 26,850)$ \\
Portsmouth & $11(\$ 18,583)$ & $40(\$ 29,282)$ & $35(\$ 25,980)$
\end{tabular}

Source: First National Savings and Loan, Western Savings and Loan, U.S. National Savings and Loan, Far West Federal Savings and Loan, Benjamin Franklin Savings and Loan, Equitable Savings and Loan, Fred Meyer Savings and Loan, Oregon Mutual Savings and Loan, Cascade Federal Savings and Loan, First State Bank, The Oregon Bank, Oregon Pioneer, The Oregon Trail. Internal files. 
TABLE XXVII

HOME IMPROVEMENT LOAN ACTIVITY SUMMARY, STUDY NEIGHBORHOODS

\begin{tabular}{llcc} 
& 1976 & 1977 & 1978 \\
& $N$ (Average) & $N$ (Average) & N (Average) \\
\cline { 2 - 2 } & $63(\$ 4,793)$ & $64(\$ 4,421)$ & $61(\$ 5,826)$ \\
Creston & $13(\$ 6,233)$ & $28(\$ 4,011)$ & $11(\$ 5,314)$ \\
St. Johns & $60(\$ 3,138)$ & $52(\$ 5,299)$ & $29(\$ 6,424)$ \\
Portsmouth & $9(\$ 3,375)$ & $17(\$ 6,775)$ & $16(\$ 4,368)$
\end{tabular}

Source: First National Savings and Loan, Western Savings and Loan, U.S. National Savings and Loan, Far West Federal Savings and Loan, Benjamin Franklin Savings and Loan, Equitable Savings and Loan, Fred Meyer Savings and Loan, Oregon Mutual Savings and Loan, Cascade Federal Savings and Loan, First State Bank, The Oregon Bank, Oregon Pioneer, The Oregon Trail. Internal Files. 
TABLE XXVIII

HOME MORTGAGE LOAN ACTIVITY SUMMARY: PORTLAND SMSA

1976

$\mathrm{N}$ (Average)

$11638(\$ 36,732)$
1977

$\mathrm{N}$ (Average)

$19116(\$ 40,991)$
1978

$\mathrm{N}$ (Average)

$17844(\$ 45,153)$

HOME IMPROVEMENT LOAN ACTIVITY SUMMARY: PORTLAND SMSA

$4487(\$ 3,564)$

$3847(\$ 5114)$

$4143(\$ 6167)$

Source: First National Savings and Loan, Western Savings and Loan, U.S. National Savings and Loan, Far West Federal Savings and Loan, Benjamin Franklin Savings and Loan, Equitable Savings and Loan, Fred Meyer Savings and Loan, Oregon Mutual Savings and Loan, Cascade Federal Savings and Loan, First state Bank, The Oregon Bank, Oregon Pioneer, The Oregon Trail. Internal files. 
future, a vacuum will be left where more efforts are needed.

\section{Footnotes for Chapter VIII}

1. Houses in the neighborhoods were checked for their size, amenities, and type to make sure that they were comparable.

2. For market values, the number of houses put on the market changed yearly for each of the four neighborhoods. The numbers ranged from eight to twenty-eight in a given month, for a particular neighborhood, making $F$ tests a more appropriate statistical tool than, say $T$ tests. It was not possible to retrieve additional market information due to a refusal on the part of the company providing the data to share any more of its records, which were private.

3. Assessment trends in the four neighborhoods back these findings. A study of assessed values in 400 randomly selected homes in the neighborhoods showed increases in values coinciding with the progression of the loan program in Richmond, compared to no significant increases in assessed values in St. Johns. 
CHAPTER IX

IMPACT EVALUATION

CRITERIA: SATISFACTION IEVEIS I

INTRODUCTION

In Chapter VIII, outside indicators suggested that actors IIving outside of HCD neighborhoods had not perceived sufficient changes in the community development areas to change their own policies toward HCD neighborhoods. The neighborhood survey which asked four hundred residents about specific aspects of their homes, neighbors, and neighborhoods provided a primary source of data capable of determining whether those outside perceptions held true within the neighborhoods.

Several situations could have developed as a consequence of the loan program. First, people might feel better about their neizhborhoods as a consequence of the loan activities and therefore be more willing to remain where they are, enhancing neighborhood stability. For loan recipients, the pride stemming from the accomplishment of HCD-funded home improvements could lead to a stronger identity with, and concern for, the homeowner's neighborhood. Further, even if a person in the HCD neighborhood has not applied for or been granted an HCD loan, the accomplishment of others home improvements could lead to perceptions of a more satisfactory environment.

A second consequence might be that $\mathrm{HCD}$ neighborhoods have been upgraded sociomeconomically. That is, people having a significantly 
higher sociomeconomic status in terms of income, occupation, and education level may have moved into the HCD neighborhoods as a result of HCD related improvements. However, it is possible that people have not perceived improvements taking place in their neighborhoods. Or, even when they have noticed changes, they may not show significantly higher satisfaction levels with their neighborhoods. Finally, socio-economic changes could have occurred with any of the other outcomes. To discover whether people were aware of the effects of the loan programs, residents were simply asked in the neighborhood survey whether or not they had noticed any improvements going on in their neighborhood, and if so, what kind. Then, to test for changes in people's attituces toward their neighborhoods as a consequence of the government programs, persons living in both HCD and non-HCD districts were asked to rate their neighborhoods as places to live. Four choices were given: 1=very §ood, 2=good, 3-not so good, and 4-not good at all. HCD neighborhood people should have significantly lower scores than non-HCD neighborhood respondents if perceptions of their neighborhood have improved since the start of the program. Asked about the condition of the houses in their neighborhoods, they should show the same difference. At the same time, more HCD area people should have responded "getting better" when asked if their neighborhood was getting better, staying the same, or getting worse. Finally, when asked the question, "All things considered, how satisfied or dissatisfied are you with this nelghborhood as a place to live, 1-completely satisfied, 2-most satisfied, 3-neutral, 4-mostly dissatisfied, 5-completely dissatisfied", the HCD neighborhoods should have shown significantly lower scores than non-HCD area people. Such information helps to isolate HCD effects on neighborhood 
residents.

Similar questions were asked about three other publicly provided services to the neighborhoods police protection, street lighting, and street repalr, as there is a very strong relationship between the level of city services and evaluation of neighborhood quality (Iovrich, 1976:208; Anton and Bowan, 1976:11-12). Dissatisfaction with such services could have a negative impact on nelghborhocd satisfaction which could, in effect, counteract positive reactions to HCD-funded improvements. In all, a total of 72 variables were used for this part of the study.

\section{FINDINGS}

NeiEhborhood Attitudes

The residents of all four neighborhoods felt positively about their environment. Eight-two percent rated their neighborhood as very good or fairly good overall. Before studying possible effects of the HCD program in this instance, several other factors found to be closely related to a person's satisfaction level should be reported. Two-way frequency tables crossing all of the variables indicating neighborhood satisfaction showed that a person's age can affect that person's satisfaction level. Generally, older respondents were relatively more likely to express a high level of satisfaction with their neighborhood (mau $C=.210$, sig=.000). Omers tended to be more satisfled with their neighborhoods than renters (Tau $C=.229$, sig $=.000$ ). The longer a person lived in a neighborhood, the more satisfied he or she was with his or her environment (Tau $\mathrm{C}=.155, \mathrm{sig}=.000$ ).

On the other hand, whether or not a person received a rehabilitation 
loan did not correlate closely with one's level of satisfaction. Nor was income related to satisfaction levels. As incomes increased, people did not express higher, or lower, levels of satisfaction with their neighborhoods.

Looking at specific responses, for St. Johns (HCD) and Portsmouth there was a significant difference in how people answered the question, "Considering everything, what would you say about this neizhborhood as a place to live? Would you say it is a very good place to live, fairly good, neither good nor bad, not very good, or no good at all?" St. Johns (HCD) showed $82 \%$ of its people rating the district as very good or fairly good, almost half $(46 \%)$ rating it very good. Although over half of Fortsmouth $(55 \%)$ also rated their neirhborhood as very good or fairly good, the difference in attitudes is substantial (33\%, $x^{2}=3.61$, sig. at . 1 ). Some of the difference could stem from several factors. More people moved to St. Johns originally because they liked the area than was true in Fortsmouth, and there is also a tendency toward longer residency in St. Johns. Public housing residents interviewed in Portsmouth were also responsible for some of the discrepancy. Even so, the difference between the neighborhoods is substantial enough to suggest that some effects of HCD activities are present.

Residents of Creston liked their neighborhood just as much, if not more, than did people in Richmond (HCD), with both neighborhoods ratinE their area highly. Elghty-three percent of the RIchnond (HCD) respondents and $91 \%$ of Creston's respondents rated their neighborhood as very good or fairly good. Moreover, over half of Creston gave their neighborhood the highest rating (57\%), while only $41 \%$ did in Richmond. Only ten people in Richmond (HCD) and nine in Creston rated their neighborhoods poorly. 
When testing for distributional differences, the two patterns were not different statistically.

To double check general neighborhood ratings, at the end of every interview, people were asked to summarize their feelings about where they live by expressing their general level of satisfaction with their neighborhoods a second time. As with the question discussed above, people showed satisfaction with where they Iive. Likewise, inhabitants of St. Johns expressed more positive feelings than did people in Portsmouth $\left(x^{2}=2.82\right.$, six. $\left.=10\right)$. Richmond $(H C D)$ and Creston showed high levels of satisfaction with $86 \%$ of Richmond and $87 \%$ of Creston respondents expressing satisfaction.

Neishborhood Changes

Whether or not people felt that their neighborhood had stayed the same, inproved, or worsened in the past three years was found to be closely related to how satisfied they were with their neighborhoods (Tau $C=.134$, sigk.001). Where there was a feeling that the neighborhood was generally improving, there was more satisfaction expressed with the neighborhood. A full $40 \%$ of St. Johns (HCD) respondents felt that their area had inproved since 1975. The same held true for only $13 \%$ of Portsmouth's inhabitants. For most Portsmouth respondents, the area seemed unchanged (75\%). Fifty-one percent of those living in St. Johns (HCD) also felt that their neighborhood was basically the same as it was three or four years ago. Still, the difference in the number of positive responses in the two neighborhoods is significant $\left(x^{2}=5.46, s i g=.025\right)$. Recalling that Richmond (HCD) and Creston were rated fairly equally in terms of satisfaction level, it should not be surprising that 
their patterns of response to questions of neighborhood change are close. Well over half of the respondents in both neighborhoods felt that their neighborhoods had not changed (Richmond (HCD) 67\%, Creston $77.5 \%$ ).

Although not significantly different in a statistical sense, a quarter of the Richmond (HCD) respondents felt that their neighborhood had changed, compared to $15.5 \%$ for Creston. Further, when people were asked how their neighborhoods had improved generally, more people in Richmond (approximately 20\%) mentioned home improvements than anywhere else. Several such comments were:

The neighborhood is going upward-young couples are buying homes and fixing them up.

It used to be run down, but everyone's improving now.

The neighborhood was getting worse-then it stopped.

It is interesting to note that although more people perceived their neishborhood as improving, people were not more satisfied with Richmond (HCD) on the whole. On the other hand, when the proportion of people perceiving improvements increases to $40 \%$ as in St. Johns, the difference in people's attitudes toward their neighborhood is significantly different.

Specific Neighborhood Improvements

Taking the issue of neighborhood change a step further, respondents were asked if they had noticed any specific improvements in their nelghborhoods in the last several years. Responses show St. Johns residents responding far more positively than the Portsmouth residents $\left(x^{2}-14.49, s i g=.001\right)$. Portsmouth residents were aware that few improvements have been made in their neighborhoods recently. 
As for specific improvements noticed, $67 \%$ of St. Johns (HCD) dwellers and $97 \%$ of the Portsmouth respondents who noticed improvements listed street improvements as the most noticeable specific betterment. In St. Johns (HCD), another $16 \%$ responded that they noticed trees being planted. Another $16 \%$ mentioned the changes going on in the St. Johns business district while one person specifically mentioned home improvements. No other improvements were noticed in Portsmouth. Richmond (HCD) and Creston residents also showed differences in whether or not they had noticed specific improvements, even though Richmond (HCD) had recelved a minimal amount of HCD monies compared with St. Johns (HCD). While over $58 \%$ of the Richmond (HCL) respondents noticed specific improvements in their neifhborhood, only $24 \%$ noticed

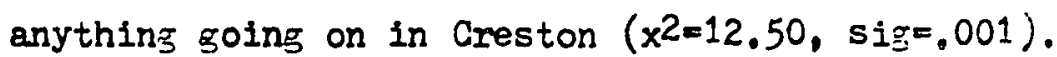

For those who noticed improvements, $40 \%$ of Richmond (HCD) and $65 \%$ of Creston Iisted street improvements as the most important changes. For over half (54\%) of the Richnond (HCD) respondents, the city's tree planting program and home improvements were apparent. Six people (Richmong (HCD), 2; Creston , 4) mentioned park improvements.

\section{WiIIIngness to Stay}

A person's willingness to stay in his or her neighborhood over a period of time has often been used as indicative of how positive that person feels about his or her immediate environment. In this survey, respondents were asked, "Five years from now, do you think you will still be living in this neighborhood?" Almost three-fourths of the people in St. Johns (HCD) answered in the affirmative. Sixty-three percent of all the Portsmouth respondents also answered positively. 
Excluding public housing residents, $71 \%$ of Portsmouth's occupants expected to live in their neighborhood for the next five years. Whereas St. Johns (HCD) residents outwardly communicated higher levels of satisfaction, the people in Portsmouth showed the same expectations of remaining where they are. In a fair number of cases, particularly in Portsmouth, people who sald that they expected to stay added that they did not think they could find housing as good as their present homes for the same price anywhere else in the city, in a sense forcing them to stay in the neighborhood. This was particularly true for several older people who, though expressing some dissatisfaction, orned their homes free and clear and had lived in the neighborhood for years. Although as many people in Portsmouth expected to remain in their neighborhood as was true in St. Johns (HCD), the1r expectations did not necessarlly indicate a high level of satisfaction with their neighborhood. Indeed, expressed levels of satisfaction discussed earlier suggest that they were not as satisfled as St. Johns (HCD) Inhabitants.

For those who expect to move, house-related reasons were most frequently given in both St. Johns (HCD) and Portsmouth. Included here are renters who expect to buy their om home in the next five years and several elderly people who plan to sell their houses because they have too much space. Two people in St. Johns (HCD) and seven in Portsmouth listed personal reasons for planning a move. Five of the latter group were public housing residents. Three expected that employment changes would necessitate moving. Finally, in Portsmouth, one person planned to move because he was uncomfortable with the thought that more blacks are moving into Fortsmouth, one woman was moving 
because she thinks Portsmouth is unsafe, and one couple felt that life in Fortsmouth was too much like living in a small town to merit staying. When the above group of persons $(\mathrm{N}=27)$ were asked where they wanted to move, over half responded "the country". A good number (8) responded simply that they wanted to move to a different part of Portland. If a specific part of Portland was mentioned, it was the southeast. Two people expected to move to another state. Both expected to move because of their jobs. Finally, one couple is moving to Bend, Oregon, asain for job-related reasons.

Fewer people expected to stay in Richmond (HCD) than in Creston (Richmond (HCD): 70.2\%; Creston: 78.9\%). That Creston shows more of a willingness to stay is largely due to the number of elderly in the neighborhood who have lived there for years and intend to stay.

Richmond ( $H C D)$ and Creston residents had different reasons for wantine to move. In Richmond ( $H C D$ ), house-related reasons and the neighborhood overerowding were most often cited. Next in line were personal and job-related reasons. For Creston, on the other hand, personal reasons came first, and jobs second. Only one person mentioned crowded conditions as a reason for moving.

As with St. Johns (HCD) and Portsmouth, most people predicted moving to the country $(\mathrm{N}=15)$. Another part of Portland is the second most mentioned place. Four people expected to move to another state and three planned to move to another part of Oregon. 


\section{PUBLIC SERVICES, RATINGS}

\section{Public Improvements}

Satisfaction with a neighborhood is closely related to how satisfied a person is with public services which are supposed to be provided in that neighborhood. In this survey, people were asked about three city services, street lighting, police protection, and streets. Crossing each of the services with neighborhood satisfaction levels shows a close relationship between the two types of variables. The happier a person is with city services, the more that person will be satisfied with his or her neighborhood (Police, Tau C $=.113$, si $\approx=.002$; Streets: Tau C=.18256, sig=.000; Lights: Tau C=.236, sie=.000). People were asked to rate each of the three services mentioned as very good, good enough, not so good, or no good. Table XXIX lists the positive ratings siven.

Hell over half of the respondents considered all three services very good or fairly good, as might be expected considering the high levels of satisfaction expressed for the four neighborhoods generally. Still, even within these categories there are some differences between neighborhoods. First, streets are given the lowest rating of all three services, with only $16 \%$ of all the Portsmouth residents and $13 \%$ of St. Johns rating streets very good. Richmond (HCD) and Creston respondents tended to rate streets higher, though fewer people rated streets very good in Richmond (HCD) (22\%) compared to Creston. Folice protection ranked next highest. Still, only $8 \%$ of the St. Johns (HCD) respondents rated their police protection as very good. In contrast, 
TABLE XXIX

SATISFACTION LEVELS WITH PUBLIC SERVICES, STUDY NEIGHBORHOODS

LIGHTS POLICE STREETS

st. Johns

VERY GOOD

268

88 138

FAIRLY GOOD

HCD

VERY GOOD

Portsmouth

FAIRLY GOOD

$60868 \% \quad 588$

\begin{tabular}{lll}
458 & 258 & 168 \\
\hline $28 \%$ & 548 & 468
\end{tabular}

Richmond

VERY GOOD

HCD

\begin{tabular}{lll}
$32 \%$ & $25 \%$ & 168 \\
\hline $28 \%$ & 628 & 588 \\
$51 \%$ & 258 & 308 \\
\hline 398 & $60 \%$ & $55 \%$
\end{tabular}

Creston

FAIRLY GOOV

VERY GOOD

FAIRLY GOOD

$60 \%$

$55 \%$ 
a full quarter of the Portsmouth respondents gave police protection highest ratings. Flchmond (HCD) and Creston are almost identical in how they rated police protection. Twenty-five percent of the residents in both neighborhoods rated police services as very good, while another $62 \%$ in Richmond (HCD) and $60 \%$ in Creston rated them as fairly good. Finally, lights were given the highest ratings of the public services overall. Almost half of the people living in Portsmouth felt that their street lighting was very good (45\%). This was almost $20 \%$ more than in St. Johns. For the second set of neighborhoods, Creston people rated their lights significantly higher than did Richmond (HCD) respondents $\left(x^{2}=5.44\right.$, sig $\left.=.025\right)$. Over half of the people living in Creston gave street lighting the highest rating. This was true for less than a third of the people in Richmond (HCD). At the same time, well over $80 \%$ of both neighborhoods gave street lighting at least a "fairly good" rating.

\section{Specific Improvements}

Concerning awareness of specific service improvements going on in their neighborhoods in the past couple of years, loan neighborhood residents are far more aware that programs are going on than are the residents of non-Ioan neighborhoods $\left(x^{2}=10.82, s 1 g=.001\right)$. Over half of the residents in St. Johns (HCD) and Richmond (HCD) stated that they had heard about city programs for people in the neighborhood. In comparison, over $90 \%$ in both Portsmouth and Creston said they had not. As might be expected, the people in non-loan neighborhoods who had noticed changes identified programs like youth programs and crime prevention programs. In Creston, several people (5) also noticed 
street improvements. Seventy-five percent of those who noticed improvements in Richmond (HCD) mentioned the HCD rehabilitation program. Other than that, several people (6) mentioned Sewall-Grest Park improvements or tree planting efforts. Two mentioned street improvements and two the city's crime prevention program, In contrast, St. Johns (HCD) responses were more diffuse. Although $30 \%$ of the St. Johns respondents mentioned the loan prograns directly, almost half of the people who noticed service improvements mentioned changes in St. Johns' business district. Seven people mentioned street improvements and four people, parks, In sum, both loan neighborhoods were highly aware of the HCD activities going on in their districts. In Richmond, where city efforts have focused on the home rehabilitation program, people mention those most frequently. In St. Johns where more funding has been funneled into the business district, people mentioned those first.

\section{Improvements Needed}

Finally, people were asked what kind of improvements they would most like to see which would make their neighborhoods better places to Iive. Overall, streets were given the highest priority (32\%). Parks and home improvements came next at approximately 12\%. No other category held over $10 \%$ of the responses. It should be noted that $14 \%$ of the respondents stated that their neighborhoods did not need any Improving.

A look at the top three types of improvements suggested in each neighborhood shows that the northern neighborhoods were more concerned with the need for social service programs for their elderly and teen populations (Table XXX). St. Johns also wanted help with some of their 
TABLE $X X X$

IMPROVEMENTS NEEDED: TOP THREE SUGGESTIONS, STUDY NEIGHBORHOODS

Parks/Home

Social Service

Improvement Programs

streets

Schools

Parks/Home

Improvement 
utilities, better water and sewer service, and better lights. In Portsmouth, parks and housing improvements ranked third.

Streets and parks/home improvements were also present in the top three rankings in Richmond (HCD) and Creston. In Richmond, people also hoped to see prograns for their children and elderly while Creston respondents frequently mentioned the need for better schools. Such responses suggest that, whlle respondents who recelved loans were satisfied with the loan programs in and of themselves, people in all of the study neighborhoods would like to see a stronger commitment to major public improvenents, such as streets.

\section{CHAPTER SUMMARY}

An Office of Management and Budget survey undertaken in 1979 reported that Portlanders were highly satisfied with their neighborhoods, with respondents living in older neighborhoods rating their districts particularly high, at 2.47 on 2 seven point scale (ONB, 1979 in.p.). The same holds true in this study. Four-fifths of all respondents rated their neighborhoods as very good or fairly good overall, with St. Johns taking the lead. Moreover, substantial percentages of HCD nelghborhood respondents perceived their nelghborhoods as improving since 1975. compared to non-loan neighborhoods.

The neighborhood survey also showed neighborhood people to be generally satisfied with their streets, police protection, and street lights, although those satisfaction levels were not as high as for the neighborhoods generally. Again, similar feelings were expressed both in the OMB study and a survey done for the Neighborhood Livability Project a year earlier. 
CHAPTER X

IMPACT EVAIUATION

\section{CRITERIA： SATISFACTION LEVELS II}

\section{INTRODUCTION}

The previous chapter reported general attitudes toward one's neighborhood for the foll study areas. This chapter moves to more specific feelings of the respondents toward their homes and their neighbors. Satisfaction levels with the space, plumbing, heating, and number of bedroons in their houses are reported, as are home improvements made since 1975 . The relationships of residents with their neighbors was studied to see if they differed in the four neighborthoods. Finally, in an effort to check for socio-aconomic changes taking place In the neighborhoods, residents were asked whether many new people were moving into their districts and if so whether they were significanly different from those already residing there.

\section{HOUSING CONDITIONS}

When asked to rate the housing conditions throughout the neighborhood, $89 \%$ of all the respondents felt that, overall, houses in their neighborhoods were either very well kept up or falrly well kept up. Approximately a third of the respondents in all of the neighborhoods gave housing conditions the most favorable rating possible. 
Approximately another half of the respondents felt that houses in their neighborhoods were fairly well kept up. Although the two loan neighborhoods showed more people rating housing conditions very high, the difference between those and the comparison neighborhoods is negligible. Creston, in faet, though it had a smaller number of people falling into the highest category, had the largest proportion of persons responding either "very well" or "fairly well" kept up of all the neighborhoods.

\section{Age of Housing}

People were asked if they had moved to an area where housing was newer, the same, or older than the housing where they lived before. In St. Johns (HCD), the largest proportion of respondents (38\%) answered that they moved to houses which were older than the ones they had Iived in previously. In contrast, only $21 \%$ of the Portsmouth respondents answered older, a significant difference $\left(x^{2}=5.95\right.$, sig $\left.=.025\right)$. When public housing residents are left out, only $6 \%$ of the people in Portsmouth live in older housing. Almost half of the Portsmouth occupants live in newer housing (48\%), while another $30 \%$ Iive in housing which approximates the age of their previous residence. When public housing residents are left out of the analysis, over half live in housing which is the same age as previous housing (36\%), while $27 \%$ Iive in newer housing.

Living in older housing does not seem to affect one's level of satisfaction in these two nelghborhoods. Although St. Johns residents tend to live in older housing, their neighborhood satisfaction levels were higher than Portsmouth. Unlike St. Johns (HCD) and Portsmouth, Richmond (HCD) and Creston 
residents showed almost identical patterns in whether they have chosen newer, the same, or older housing to live in. For both neighborhoods, the highest proportion of people lived in housing which is approximateIy as old as where they IIved before (Richmond (HCD), 45\%; Creston $39 \%$ ). The next highest category is the "older" category. Over a third of Richmond (HCD) and Creston respondents lived in homes which were older than where they had lived. Although the smallest group of people are contained in the category "newer", almost a quarter of Creston respondents lived in newer housing (24\%), while 14\% lived in newer housing in Richmond (HCD). Much of the difference in this last category is due to the higher percentage of renters living in new apartment complexes in Creston. When these people are removed, the patterns discussed above are even closer.

\section{Crowding}

As compared to where they lived before, the greatest proportion of St. Johns (HCD) residents lived in more crowded conditions (36\%) at the time of the survey. Thirty-five percent live in housing as crowded as their previous residence, while $29 \%$ live in less crowded housing. In comparison, Portsmouth residents showed more of a tendency to rate their neighborhood as equally as crowded as where they lived before. Worthy of note is that more crowded neighborhood conditions do not seem to lead to lower nelghborhood satisfaction levels.

In terms of crowdedness, Richmond (HCD) and Creston show a relationship closely resembling that of St. Johns (HCD) and Fortsmouth. For Richmond(HCD) more weight fell on the side of "more crowded" than in Creston, where people said their nelghborhood was as crowded as where 
they lived before. Such differences did not prove to be significantly different statistically. That the neighborhoods were rated equally suggests that crowding in and of itself does not affect satisfaction levels. It does not decrease satisfaction levels, nor does it increase those levels.

\section{Satisfaction with House}

Over $90 \%$ of the survey population said that they were either very satisfied or mostly satisfied with their own living quarters. Homeowners were more satisfied than renters (Tau C-.228, sig=.,000). In St. Johns (HCD), 86\% rated their homes as satisfactory. In Portsmoutin, $84 \%$ of its inhabitants reported satisfaction. Public housing residents had a dichotomous effect on Portsmouth's levels of satisfaction. On the one hand, public housing residents tended to be the respondents who give their homes the lowest rating. on the other hand, several public housing residents gave their apartments the highest rating. Hence, when public housing residents are removed from the analysis, Portsmouth had fewer dissatisfied people and fewer highly satisfied people. Overall, approximately half of St. Johns (HCD) and Portsmouth respondents stated that they were highly satisfied with their homes (St. Johns (HCD), 50\%; Fortsmouth: 57\%). Without public housing residents, that group for Portsmouth falls to a quarter of the total.

Rlchmond ( $H C D)$ and Creston showed a higher level of satisfaction with their homes than was the case in St. Johns (HCD) and Fortsmouth. A very high percentage, $64 \%$ for both neighborhoods, maintained that they were very satisfled with their homes. Close to another third were 
mostly satisfied with their housing units (Richmond (HCD): $33 \%$;

Creston: 30\%). leaving under 6\% for either neighborhood showing any dissatisfaction.

\section{Specific Housing Characteristics}

In addition to rating their homes generally, respondents were asked to rate the space, number of bedrooms, heating, and plumbing as very good, good, not so good, or not good. Again, people were generally satisfied with all of those characteristics. As can be seen in Table XXXI, with regard to all the individual housing characteristics, more people in Portsmouth responded very good than was true in St. Johns (HCD), in spite of the fact that the neighborhoods showed the same high level of satisfaction with their homes generally. The differences in the four characteristics shown in the table are most noticeable when heating and plumbing were rated. Twenty-seven percent more respondents in Fortsmouth than in St. Johns (HCD) rated their heating (not including public housing residents) higher. Twenty-two percent rated plumbing higher. Nonetheless, recall that St. Johns (HCD) residents were highly satisfied with their homes. It may be that people in St. Johns (HCD) expected to have problems with their heating and plumbing since they tended to own older homes. Because of that, they may not have held their frustrations with specific functions against the house Itself. 
TABLE XXXI

HOUSING CHARACTERISTICS, ST. JOHNS AND PORTSMOUTH

\begin{tabular}{|c|c|c|c|c|c|c|c|c|}
\hline & \multicolumn{2}{|c|}{ Snano } & \multicolumn{2}{|c|}{ Podranc } & \multicolumn{2}{|c|}{ Heating } & \multicolumn{2}{|c|}{ Flumbing } \\
\hline & & & & & & $\%$ & & 8 \\
\hline & $\begin{array}{l}\text { Very } \\
\text { Good }\end{array}$ & Good & $\begin{array}{l}\text { Very } \\
\text { Good }\end{array}$ & Good & $\begin{array}{l}\text { Very } \\
\text { Good }\end{array}$ & Good & $\begin{array}{l}\text { Very } \\
\text { Jood }\end{array}$ & Sood \\
\hline St. Johns (HCD) & 68 & 17 & 64 & 22 & 59 & 29 & 57 & 30 \\
\hline Portsmouth & 71 & 16 & 76 & 13 & 75 & 15 & 75 & 22 \\
\hline
\end{tabular}

With regard to the number of bedrooms and amount of space, both Richmond (HCD) and Creston showed very high levels of satisfaction as evidenced in Table XXXII. For both neighborhoods, three-quarters of the respondents rated the amount of space in their homes and the number of bedrooms as very good. Richmond (HCD) respondents gave somewhat higher ratings to their plumbing and heating, however. Thirteen percent more Richnond residents rated both characteristics as very good. Still, since Creston and Richmond (HCD) rated their homes equally overall, satisfaction or dissatisfaction with specific parts of one's home again does not seem to affect overall feelings about where one resides. The presence of HCD loan programs in Richmond and St. Johns has not lead to significant differences in how residents feel about their homes.

TABLE XXXII

HOUSIN; CHARACTERISTICS, RICHMOND AND CRESTON

\begin{tabular}{|c|c|c|c|c|c|c|c|c|}
\hline & \multicolumn{2}{|c|}{$\begin{array}{c}\text { Space } \\
\%\end{array}$} & \multicolumn{2}{|c|}{$\begin{array}{c}\text { Bedrooms } \\
\varnothing\end{array}$} & \multicolumn{2}{|c|}{$\begin{array}{c}\text { Heating } \\
\varnothing\end{array}$} & \multicolumn{2}{|c|}{$\begin{array}{c}\text { Plumbing } \\
.6\end{array}$} \\
\hline & $\begin{array}{l}\text { Very } \\
\text { Good }\end{array}$ & Good & $\begin{array}{l}\text { Verry } \\
\text { Good }\end{array}$ & Good & $\begin{array}{l}\text { Very } \\
\text { Good }\end{array}$ & Good & $\begin{array}{l}\text { Very } \\
\text { Good }\end{array}$ & Good \\
\hline Richmond (HCD) & 77 & 20 & 74 & 22 & 74 & 21 & 68 & 24 \\
\hline Creston & 75 & 19 & 77 & 19 & 61 & 30 & 55 & 35 \\
\hline
\end{tabular}


Housing Improvements

The survey found that most homeowners in St. Johns (HCD) and Richmond (HCD) had made home improvements since 1975. Even people surveyed who were not known $H C D$ loan reciplents had made improvements (St. Johns: 80\%; Richmond: 92\%). In Portsmouth, in contrast, a little over half have made improvements and in Creston less than half of the homeowners have. In Richmond (HCD), the home improvement loan programs accounted for approximately half of the rehabilitation work done in the neighborhood, according to survey respondents. For St. Johns, closer to three-quarters of those doing work on their homes paid for that work with HCD funds.

Feople who fixed up their homes without getting a rehabilitation loan paid cash for the most part. Only nine people in all reported getting commercial loans. Most of these people were in the non-loan neishborhoods, four in Creston and four in Portsmouth.

\section{Iypes of Improvements}

Respondents were asked to list the type of improvements they had made on their homes. Table XXXIII shows the top five improvements mentioned in each neighborhood, starting from most important. The type of work done in the loan neighborhoods was more substantial than in the non-loan neighborhoods, and the ordering of the improvements differs. St. Johns (HCD) and Richnond (HCD) listed insulation, outside structural work, kitchen remodeling, work to bring their plumbing and wirin up to code, and roof work most frequently. For both neighborhoods, outside structural improvements ranked first or second. In St. Johns (HCD), insulation was the most frequently mentioned improvement. 
MOST FREQUENT HOME IMPROVEMENTS, STUDY NEIGHBORHOODS

st. Johns (HCD)

1. Insulation

2. Outside Structural Improvement

3. Kitchen Remodeling

4. Roof Work

5. wiring and Plumbing
Portsmouth

Outside structural Improvement

General Remodeling

painting

Insulation

Floor Work
Richmond (HCD)

Outside structural Improvement

wiring and Plumbing

Roof Work

Kitchen Remodeling

Insulation
Creston

Insulation

painting

General Remodeling

Wiring and plumbing 
In contrast, insulation ranked fifth in Richmond (HCD). Wiring and plumbing improvements were ranked relatively higher in Richmond (HCD). Roof work and kitchen remodeling ranked either third or fourih in both neighborhoods.

The non-loan neighborhoods differed in their choice of improvements made. As in the loan neighborhoods, insulation ranked as one of the five most frequently mentioned improvements. The only other two types of improvements the non-loan neighborhoods had in common tended to be fairly minor types of rehabilitation work, particularly in terms of costs such as painting and remodeling work. In Portsmouth, people ranked outside improvements first. In Creston, several people (7) mentioned that they had brought their homes up to code with wiring and plumbing improvements, suggesting that some rehabilitation of older homes was occurring in Creston as well as in St. Johns (HCD) and Richnond (HCD) even without the loan program.

\section{Neighborhood Effects}

When asked, "Do you think improving your home has affected the neighborhood at all?", a solid majority of all of the home improvers responded "yes". When asked how, most answered that they felt that the quality of the nelghborhood went up. Others thought that their work gave others the incentive to do some improvements of their own.

St. Johns (HCD) and Portsmouth showed a $20 \%$ difference in their responses to this question. While $73 \%$ of the St. Johns (HCD) respondents perceived a better neighborhood, 52\% of Portsmouth respondents felt that way. Although not as great a difference, Richmond (HCD) also showed a larger proportion than Creston in the percentage of persons 
who felt that their efforts improved their neighborhood (Richmond (HCD): 69\%; Creston: 63\%).

Likewise, more people in the loan neighborhoods were affected by their neighbors working on neighborhood homes. Ten percent more people both in St. Johns (HCD) and Richmond (HCD) were affected than in the non-loan neighborhoods. A table of response patterns to the question, "Do you think your neighbors improving their homes affected you at all?", is given below:

\section{TABIS XXXIV} RESIDENT REACTION TO HONE IMPROVEMENTS BY NEISHBORS

\begin{tabular}{lcccc} 
& $\begin{array}{c}\text { St. Johns } \\
\text { (HCD) }\end{array}$ & Portsmouth & $\begin{array}{c}\text { Richmond } \\
\text { (HCD) }\end{array}$ & Creston \\
\cline { 2 - 5 } Yes & $35 \%$ & $23 \%$ & $27 \%$ & $17 \%$ \\
No & $65 \%$ & $77 \%$ & $72 \%$ & $83 \%$
\end{tabular}

\section{SATISFACTION LEVEIS: NEISHBORS}

Neighbor Rating

Throughout this study, a serious effort was made to try to isolate variables outside of the HCD programs which might affect residents' attitudes toward their neighborhoods. The condition of other public services, such as those covered in Chapter VIII, could affect satisfaction levels. The characteristics of the residents themselves, as reported in the next chapter, could be related to different levels of satisfaction. Or people's feelings about their neighbors could have some effect. The survey showed that all of the respondents rated their neighbors highly. When asked, "What about the people who live around here? As neighbors would you say that they are very good, 
fairly good, neither good nor bad, not very good, or not good at all?", half responded very good. This was true for all of the neighborhoods, though loan neighborhoods rated their neighbors slightly higher. Only one of the neighborhoods, Portsmouth, had a noticeable number of persons rating their neighbors as not very good or not good. These were public housing residents who acknowledged that they tended to feel that way for the most part because they did not know many of their neighbors. Neighbor ratings were not affected by the number of nearby neighbors whose names were known. For all the neighborhoods, visiting patterns tended to cluster into people who only visited with several of their neighbors and those who visited with everyone around them. Fiftysix percent of the people in St. Johns and $51 \%$ of the people in Portsmouth have visited with fewer than four of their closest neighbors. At the other extreme, $22 \%$ and $27 \%$ of the two neighborhoods respectively have visited with all ten of their closest neighbors.

Although Richmond (HCD) and Creston respondents gave comparatively high ratings to their neighbors, in RAchmond (HCD) people tended to visit with pore of their neighbors than was true in Creston ( $\left.x^{2}-4.02, s i g=.05\right)$. Where $43 \%$ of Richmond (HCD) respondents have visited with fewer than four of their closest neighbors, the same held for $60 \%$ of Creston. At the other end of the spectrum, a quarter of the people living in Richmond (HCD) have visited with as many as ten of their closest neighbors. This was only true for $15 \%$ of the Creston respondents.

\section{Neu People}

Respondents were also asked if they had noticed many new people moving into their neighborhoods in the past several years. All four 
neighborhoods split approximately 50-50 on that question. St. Johns (HCD) residents had a slight tendency (57\%) to respond that they had not noticed many new people moving in while Richmond (HGD) and Creston had a slight tendency to respond positively to the question (Richmond (HCD): 58\%; Creston: 60\%) as did Portsmouth (51\%). Of those who sald that new people had been moving in, a little over half said that the type of residents had changed. At the same time, both loan nelghborhoods differed to some extend with the non-loan neighborhoods in whether they thought the type of new resident was different. Only $40 \%$ of the St. Johns respondents thought a different type of person was moving in, while the same was true for $57 \%$ of Portsmouth. In Richmond (HCD), 68\% of the people who have noticed new people moving In feel that the type of person is changing. The same held for exactly half of Creston $\left(x^{2}=2.90\right.$, sig $\left.=.10\right)$.

Among those seeing changes, $71 \%$ overall said that younger couples or singles were moving in. Fourteen percent said that younger families were moving in, and $8 \%$ said "worse" in the sense of being more transient. Portsmouth was the only neighborhood uhere respondents mentioned older people moving in. The table belor outlines the classification of responses for all the neighborhoods?

TABLE XXXV

TYPE OF NEW RESIDENT, STUDY NEIGHBORHOODS

\begin{tabular}{lcccc} 
& $\begin{array}{c}\text { St. Johns } \\
\text { (HCD) }\end{array}$ & Portsmouth & $\begin{array}{c}\text { Richmond } \\
\text { (HCD) }\end{array}$ & Creston \\
\cline { 2 - 5 } Younger Couples & $53 \%$ & $61 \%$ & $85 \%$ & $76 \%$ \\
Younger Families & $23 \%$ & $18 \%$ & $9 \%$ & $10 \%$ \\
Older & & $11 \%$ & &
\end{tabular}


TABLE XXXV (ContInued)

TYPE OF NEW RESIDENT, STUDY NEIZHBORHOODS

\begin{tabular}{ccccc} 
& $\begin{array}{c}\text { St. Johns } \\
(\text { HCD) }\end{array}$ & Portsmouth & $\begin{array}{c}\text { Richmond } \\
\text { (HCD) }\end{array}$ & Creston \\
\cline { 2 - 5 } "Worse" & $12 \%$ & $7 \%$ & $6 \%$ & $10 \%$ \\
Blacks & $12 \%$ & $3 \%$ & & $4 \%$ \\
N & 17 & 28 & 33 & 29
\end{tabular}

Finally, well over half of all respondents noticed their neighbors making home improvements in the last few years. Comparing loan nelghborhoods with non-Ioan neighborhoods shows $15 \%$ more people noticing improvement activities in St. Johns (HCD) and Richmond (HCD) (Table $X X X V I)$.

TABLE XXXVI

THOSE NOTICING NEIGHBORS' WORK EFFORTS, STUDY NEIJHBORHOODS

St. Johns (HCD)

$\frac{\text { Yes }}{70 \%} \quad \ldots \ldots . . . . . \frac{\text { No }}{30 \%}$

Portsmouth

$63 \%$

$37 \%$

Richmond (HCD)

$85.1 \%$

$14.9 \%$

Creston

$60.9 \%$

$39.1 \%$

$n=400$

\section{CHAPTER SUMMARY}

Generally, resldents felt very good about their housing and their neighbors, with loan neighborhood occupants rating housing conditions slightly higher than those in non-loan neighborhoods. Where home 
improvements were made, loan neighborhoods showed far more effort going into major rehabilitation work compared to the cosmetic repair work that tended to be found in the comparison neighborhoods. People who fixed up their homes belleved that their work affected their neighborhoods in a positive way, making them better places to live. HCD residents felt this more strongly than did non-loan neighborhood occupants, suggesting that where people see changes taking place in their environment, particularly if they take part in those changes, they are affected positively.

Considering the last two chapters together, HCD neighborhood residents were aware of the city's actions in their districts. Yet the rehabilitation loan programs, as implemented by the Portland Development Comnission, did not substantially increase levels of satisfaction with nei Thborhoods. Instead, so many factors contributed to a person's perception of his or her environment that only where the fovernment frograms were broadened to other activities, as was true of the HCD activities in St. Johns, could one see even moderate increases in neighborhood satisfaction levels.

At the same time, inhabitants of neighborhoods where the loan programs have been focused do show positive feelings regarding specific loan-related changes. They agree that their neighborhoods have improved since the inception of HCD activities. The majority of homeowners in loan neirhborhoods have fixed up their homes in the last several years and feel that their efforts and the efforts of their neighbors have helped the neighborhood. 
CHAPTER XI

IMPACT EVALUATION

CRITERIAI NEIGHBORHOOD DIFFERENGES

INTRODUCTION

The neighborhood survey included a dozen questions asking for socio-economic information from respondents. There were two reasons for this. First, as mentioned earlier, it was possible that variables other than the HCD Ioan programs could have affected people's attitudes toward their nelghborhoods. For example, if people tend to feel better about their neighborhood the older they got, then a significantly hizher proportion of elderly persons living in one of the control neighborhoods might camouflage increased levels of satisfaction that might be felt in HCD neighborhoods as a consequence of the loan programs. Second, the information was needed to test whether the loan neighborhoods were upgrading socio-economically.

\section{Income Levels}

Over half of the respondents in both St. Johns (HCD) and Portsmouth earn under $\$ \$, 000$ per month. Approximately one quarter more earn $\$ 1,000$ - $\$ 1,500$ while the remainder of the respondents have incomes of over $\$ 1,500$ per month.

Richmond ( $H C D$ ) and Creston incomes tended to be a little higher than their north Portland counterparts. While the median income in 
Richmond (HCD) fell into the $\$ 1,000-\$ 1,500$ group, Creston centered more in the $\$ 500$ - $\$ 1,000$ range. Table XXXVII shows hou incomes of respondents were distributed in the four neighborhoods.

TABLE XXXVII

\begin{tabular}{|c|c|c|c|}
\hline North & Portland & Southeast & Portland \\
\hline $\begin{array}{c}\text { St. Johns } \\
\text { (HCD) }\end{array}$ & Portsmouth & $\begin{array}{l}\text { Richnond } \\
\text { (HCD) }\end{array}$ & Creston \\
\hline $19 \%$ & $28 \%$ & $15.8 \%$ & $23.1 \%$ \\
\hline $40 \%$ & $30 \%$ & $29.5 \%$ & $34.1 \%$ \\
\hline $21 \%$ & $21.5 \%$ & $29.5 \%$ & $15.4 \%$ \\
\hline $20 \%$ & $20.4 \%$ & $25.3 \%$ & $27.5 \%$ \\
\hline$\$ 500-\$ 1,000$ & $\$ 500-\$ 1,000$ & $\begin{array}{l}\$ 1,000- \\
\$ 1,500\end{array}$ & $\$ 500-\$$ \\
\hline
\end{tabular}

Age

As shown in Table XXXVIII, St. Johns (HCD) and Portsmouth closely resemble each other in their age characteristics. Although the median age in both neighborhoods falls in the 40-50 age group, respondents tended to cluster into youns couples under thirty and a more middleage group, ranging from 40-60. Approximately a third of the people In both neighborhoods were under 30 years of afe. Twenty-one percent of the St. Johns (HCD) respondents were old enough to be retired, while $26 \%$ of the Portsmouth residents were over 60 years of age, excludin public housing residents. When public housing residents are included, $14 \%$ of the Portsmouth respondents were over aze 60. 
TABLE $X X X V I I$

RESPONDENT AGES: NORTH PORTLAND

\begin{tabular}{lcc} 
Afe Categories & $\begin{array}{c}\text { St. Johns (HCD) } \\
\text { (Percent) }\end{array}$ & $\begin{array}{r}\text { Portsmouth } \\
\text { (Percent) }\end{array}$ \\
\hline Under 20 & 34 & 1.2 \\
$20-30$ & 12.8 & 27.2 \\
$30-40$ & 14.9 & 14.8 \\
$40-50$ & 17 & 16 \\
$50-60$ & 12.8 & 14.8 \\
$60-70$ & 8.5 & 11.1 \\
Over 70 & 100 & 14.8 \\
N=200 & $40-50$ & 100 \\
Median & $170-50$
\end{tabular}

Although Richmond (HCD) and Creston showed the same age patterms as the northern neizhborhoods, they differed in the number of elderly persons living in each neighborhood. One-quarter of the Richmond (HCD) respondents and a full $40 \%$ of the Creston residents were over age 60 at the beginning of 1979. Not only did the neighborhoods differ significantly in their age distributions $\left(x^{2}=5.82\right.$, sig=.025) ${ }^{1}$, but the differences in age groups seemed to be increasing. A 6\% difference in those over age 60 in 1970 expanded to a difference of over 16\% in 1979-more than doubling the proportion of elderly in Creston when compared to Richmond (HCD) (Table XXXIX). 
TABLE XXIX

RESPONDENT AGES: SOUTHEAST PORTLAND

\begin{tabular}{lcc} 
Age Categories & $\begin{array}{c}\text { Richmond (HCD) } \\
\text { (Percent) }\end{array}$ & $\begin{array}{c}\text { Creston } \\
\text { (Fercent) }\end{array}$ \\
\hline Under 20 & 2.3 & 1.0 \\
$20-30$ & 30.7 & 28.1 \\
$30-40$ & 20.5 & 10.4 \\
$40-50$ & 12.5 & 3.1 \\
$50-60$ & 8.0 & 16.7 \\
$60-70$ & 11.4 & 15.6 \\
Over 70 & 13.8 & 25 \\
N=200 & 100 & 100 \\
Median & $30-40$ & $50-60$
\end{tabular}

\section{Marital Status}

Well over half of the respondents in both northern nei-hborhoods are married (St. Johns : 58\%; Portsmouth $52 \%$, without public housing: 60\%). The other two categories showing noticeable percentages are "widow" and "single". Sixteen to seventeen percent of total responses fall into the "widow" catezory for both places. Similarly 11-12\% labeled themselves "single", not counting those living in public housing. Including public housing residents raises the single group firure to 17:0 in Portsmouth.

As with St. Johns (HCD) and Portsmouth, over half of the respondents in the Southeast neighborhoods were married. (Richmond (HDD): 62\%, Creston: 52\%). A greater proportion of single people lived in Creston (Creston: 20\%; Richmond, 10\%). As might be expected considering the age 
differences in the two neighborhoods, more people reported "widow" status in Creston than in Richmond (Creston: 19\%; Richmond (HCD), 13\%). Richmond, on the other hand, reported more divorces by 5\% (Richmond (HCD) 8 11\%; Creston: $7 \%$ ).

Even with such differences, the overall marital status patterns, i.e., the proportions of married people, of divorced people, of singles, etc., were not sionificantly different for either of the sets of neizhborhoods.

\section{Family Size}

Portsmouth and St. Johns (HCD) showed parallel patterns in terms of family size distributions. Families tended to be small, reflecting the substantial widow and single populations. Well over half of the respondents lived in families of two or less. Only $13 \%$ of the respondents in St. Johns and only $10 \%$ of those in Portsmouth had families larger than four.

Richmond (HCD) and Creston were also fairly similar in family size patterns. The average family tended to be much smaller than that of St. Johns or Portsmouth, due to large numbers of single people, divorced people, and widows. Although $12 \%$ of the Richmond households were larser than four, only $3 \%$ of the Creston respondents had families that large. Instead, over three-fourths of Creston is comprised of married couples or single households.

\section{Education Levels}

In education, respondents for St. Johns (HCD) and Portsmouth repcrted similar education levels. Sixty-five percent in St. Johns 
(HCD) and half of PC tsmouth had earned a hish school degree. Seven percent in St. Johns and 17\% in Portsmouth only completed grade school. Of the remaining third, most respondents had taken some college courses, thourh few had earned their BA degrees (St. Johns (HCD), 6\%; Portsmouth: 2\%). When public housing residents are excluded from the analysis, the patterns hold.

Comparins Richmond (HCD) with Creston shows Richmond (HCD) with a solid number of residents with college dezrees (22\%) compared to Creston (10\%). This was true both for respondents and theix spouses. Over twothirds of the respondents in Creston stopped at high school (65\%). In contrast, almost half of Richmond (HCD) respondents had some college education.

Stated in another way, the Richmond neighborhood shows higher levels of education. When spouse levels are compared, the pattern differences become even more clear. In Richmond, Iess than half of the spouses $(48 \%)$ ended their education at high school. In contrast, almost two-thirds of the Creston spouses (62\%) stopped at high school. Even with such differences, the median test was not statistically significant.

\section{Work Status}

People were asked whether they or their spouses worked full-time, if either or both worked full-time, if either or both were unemployed, and finally whether they received any income through benefits such as a pension, welfare, social security, or unemployment.

Several pattem categories are noteworthy. First, in almost three-fourths of the respondent homes in St. Johns (HCD) : 72\%, someone worked full-time. Of those households, over a third were comprised of 
couples where both partners worked full-time. Approximately a quarter were households where a woman was the chief breadwinner, while the remainder had a man working full-time. Over half (54\%) of the respondent households in Portsmouth also had at least one full-time worker. Excluding public housing residents increases the proportion to 60 . As In St. Johns (HCD), approximately a third of these households had both a man and woman working full-time. About $10 \%$ of all the Portsmouth households reported a woman acting as head of household, working furltime. The remainder consisted of households in which a man worked full-time ( $28 \%$ with public housing: $31 \%$ excluding public housing). Two other categories included in work status deserve mention. First, retired persons on social security and/or pensions made up $14 \%$ of the St. Johns (HCD) respondent population and 23\% of Portsmouth's. When public housing residents are left out, a quarter of the Portsmouth residents were retired. Of this group, elght people in St. Johns (HCD) and seventeen in Portsmouth reported that they received pensions as well as social security. Translated into percentages, $60 \%$ of the retired people in St. Johns (HCD) and $80 \%$ of the retired persons in Portsmouth had small pensions added to their social security.

Approximately $10 \%$ of the St. Johns (HCD) respondents were unemployed. Controlling for public housing residents, Portsmouth showed half that high a percentaze; with public housing residents included, unemployment in Portsmouth is as high as $15.5 \%$.

Richmond (HCD) and Creston also had a majority of households with at least one full-time worker. For Rlchmond, $7^{9 \%}$ of the households had someone working full-time. For over half of these families, a man was 
the full-time worker. In over a third, a man and woman were working full-time. Eleven percent of the Richmond (HCD) households had a woman working full-time. Creston showed a comparable distribution for work status. Over half of the households included someone who was employed full-time. Of these, half had a male full-time worker. Iike Richmond (HCD), more than a third of the group consisted of families in which a man and a woman both worked full-time. Finally, $11 \%$ of the Creston respondent population was comprised of households in which only a woman was employed full-time.

Taking the age distribution reported earlier into account, one would expect more retired people to live in Creston than in Richmond (HCD). Indeed the survey results show $38 \%$ of the Greston respondents listed as retired, while the flowre for Richmond (HCD) is only half of that. In addition, $62 \%$ of those retired in Creston received a pension as well as social security, while $53 \%$ did in Richmond (HCD).

\section{Other Forms of Income}

Few people reported receiving forms of income other than paychecks, social security, and pensions. Since the St. Johns (HCD) and Portsmouth areas both have public housing complexes, both neighborhoods have a noticeable number of welfare reciplents. For St. Johns (HCD) the percentages of respondents reporting welfare payments was $15 \%$, compared to $18 \%$ for Portsmouth. Neither Richmond (HCD) nor Creston had a signiflcant number of welfare reciplents, possibly as a reflection of the lack of public housing in both neighborhoods; each neighborhood had two persons reporting a welfare income. In all, only two people reported having a second job. Both of these people lived in Portsmouth. Five 
stated that they were receiving unemployment compensation. of these, one person was from Portsmouth, one from Creston, and three from Richmond (HCD).

HOUSING CHARACTERISTICS

\section{Housing Structures}

For all four nelghborhoods, over three quarters of the respondents lived in single family houses (St. Johns (HCD): 87\%; Portsmouth: 75\%; Richmond (HCD), 96\%; Creston: 79\%). The comparison neighborhoods, Portsmouth and Creston, showed lower percentages on the whole. The only other type of structure housing a sionificant percentage of the population was the type consisting of 10 or more units. Including public housins complexes, over $12 \%$ of St. Johns (HCD) residents lived in such buildings. For Portsmouth, the percentage was higher (22\%). Richmond (HCD) and Creston showed fewer people living in large complexes. For Richmond (HCD) only three people İved in apartment bulldings of ten units or more; Creston had 16 people in that category.

\section{Home Omership}

As for home omership, far more respondents owned their homes than rented for all of the nelghborhoods. The two loan areas, St. Johns and Richmond, had a higher ratio of homeowners to renters than did the comparison neighborhoods as can be seen from Table $X I L$. 
TABLE XI

HOMEOWNERSHIP PATTERNS \& STUDY NEIGHBORHOODS

\begin{tabular}{|c|c|c|}
\hline & Own & Rent \\
\hline St. Johns (HCD) & $74 \%$ & $25 \%$ \\
\hline Portsmouth & $62 \%$ & $3 \%$ \\
\hline Richmond (HCD) & $82 \%$ & $18 \%$ \\
\hline Greston & $69 \%$ & $30 \%$ \\
\hline
\end{tabular}

Three quarters of St. Johns (HCD) and fourufifths of Richmond's (HCD) respondents owned their homes. In contrast, the comparison neighborhoods showed two-thirds of their respondents as homeowners. There remains more than a $10 \%$ difference in the rate of homeownership between loan and non-loan neighborhoods.

Perhaps more important than these differences are the changes in home ownership patterns which have occurred since 1970. In that year, the approximate ratio of homeowners to renters in St. Johns (HCD) was $1.5: 9$; it has since doubled. In Portsmouth, the ratio was approximately .75:1. Now it is approximately 312 , again a substantial increase. For Richmond (HCD) and Creston, the changes in proportion have been different. In Richmond (HCD) the proportion of homeowners has quadrupled in an eight-year period, now standing at four homeowners for every renter. In 1970, Creston had an approximate owmer to renter ratio of 111. That ratio stands at a little over $2: 1$. Where the proportion of owners to renters seems to have increased, the chanze is only half that experienced in Richmond (HCD).

Finally, when asked whether or not they have ever owned homes 
before, most people surveyed had not. In St. Johns (HCD) and Portsmouth, less than a third of the respondents owned homes previously (St. Johns (HCD): 29\%; Portsmouth 30\%). The percentages were higher in Richmond (HCD) $(36 \%)$ and highest in Creston where a full $42 \%$ of the respondents had ormed a home before.

Ienrth of Residence

In North Portland, people tended to have lived longer in St. Johns (HCD) than in Portsmouth. While almost half of the people iiving in Portsmouth had lived there less than five years, the same held true for only $37 \%$ of those people Iiving in St. Johns (HCD). As many as one in five persons living in St. Johns (HCD) had lived there for a lifetime. Only $12 \%$ of the people livins in Portsmouth had never lived anywhere else.

Very few people had resided in Richmond (HCD) or Creston for all of their lives. In contiast, almost half of the people living in both nei hhborhoods had been there under five years. The remainder divided up fairly evenly into those who have lived in their homes 5 to 10 years, 10 to 20 , or over 20 years. Such patterns held for both neighborhoods.

\section{Place of Previous Residence}

Generally, for people who have not lived in their neighborhoods for a Iifetime, three-quarters lived somewhere in Portland before they moved to their present residence. Within St. Johns (HCD) and Portsmouth, most people moved from a neighborhood closer to downtown than their present address (St. Johns (HCD) : 55\%; Portsmouth:33\%). In Doxtsmouth, more people moved in from a neighborhood considered to be farther away from 
downtown. Usually, though, they had moved from St. Johns (HCD) to Portsmouth. About a tenth of the respondents moved to their present homes from another in the same neighborhood.

A look at other possibilities shows that a considerable number of respondent: had moved to Portland from other cities, both inside and outside of Oregon. For Portsmouth, almost one in every five persons moved to Portland from a different city. Though this was true for relatively fewer people in St. Johns (HCD), it was still true for $16 \%$ of the respondents. For the most part, the cities mentioned were outside of Oregon. Approximately five people mentioned Vancouver, Washington. Other than that, cities were spread nationwide, including New Orleans, Kansas City, and points east.

Similarly, over three-quarters of the residents in both Richmond (HCD) and Creston had lived in Portland before they moved to their present residence. For Richmond (HCD) almost a fourth of the respondents moved from somewhere else in the same neighborhood. This was also true of $18 \%$ of the Creston respondents. When people moved from different Portland neiphborhoods, they tended to move out to Creston from a neighborhood closer to downtown ( $31 \%$ ) and in to Richmond (HCD) from a neishborhood farther away (37\%). The only other category worthy of note is "city other than Portland (Richmond (HCD), 11\%, Greston: 13\%)."

Reason for Neighborhood Cholce

For the most part, four reasons underlay respondents' decisions to Iive in St. Johns (HCD) and Portsmouth. About a third of the reasons given were house-related. Most often the reason cited was because the respondent had found a house to buy in the neighborhood. Several qualified their answers by explaining that housing was inexpensive in North 
Portland.

Personal reasons also ranked high. Included in this category are responses where a person's marital status changed, where a person wanted to move closer to his or her extended family, or where a person stated "It's personal." Approximately a quarter of the respondents for both neighborhoods gave this response.

Wore people moved to Portsmouth than to St. Johns (HCD) because of job-related reasons (St. Johns (HCD), 13\%; Fortsmouth, 17\%), Conversely, almost a quarter of the people moving to St. Johns (HCD) (22\%) did so because they liked the area. This was true for only $13 \%$ of Portsmouth's inhabitants.

Far more people in Richmond (HCD) and Creston moved to their neizhborhoods because they found houses to buy than was true in St. Johns and Portsmouth. Well over half of all respondents listed houserelated reasons (Richmond (HCD), 67\%; Creston $155 \%$ ) when asked why they moved to their neizhborhoods. For Richnond (HCD), the only other catergory containin - over $10 \%$ of the population was "facilities"; $12 \%$ moved to Richmond (HCD) because it was close to downtown, buslines, stores, etc. Creston does not show as lare a percentage of people Iistine facilities as the primary reason for moving to the neishborhood (9\%). Instead, personal reasons were the foremost reason for settling in Creston for almost a quarter of the respondents.

When the distributions of responses were compared, neither of the sets of neighborhoods showed patterns which were siønificantly different. 
CHAPTER SUMMARY

This chapter shows four neighborhoods with residants of relatively low socio-economic status. For St. Johns (HCD), Portsmouth, and Creston, the modal catezory of incomes was $\$ 500$ to $\$ 1,000$ while Richmond (HCD) residents eamed slightly higher amounts. All of the neighborhoods had clusters of youncer married couples and a retired group, with Creston takin: the lead. The most frequently encountered marital status was married, with widows and widowers forming the second largest group. For all nei-hborhoods, family sizes tended to be small, due to younger families with fewer children and older couples whose children had left home. Iducation levels tended to be low, with most people in St. Johns (HCD) and Portsmouth and half of Richmond (HCD) and Creston respondents stopping at hith school. Richmond (HCD) showed the hizhest education levels of the four nei-hborhoods, Over half of all households had at least one person workin; full-time, with loan neirhborhoods showing slightly hioher percentages of employed persons than the non-loan neighborhoods. More homeowners than renters lived in all four neighborhoods, with the HCD nel:hborhoods showing slishtly larger proportions of homeowners.

Over half of the residents in each area had lived in their homes for over five years. Most moved from somewhere else in Portland, usually because they found a house they could afford.

Several other studies performed over the last year were consulted to verify some of the findings related above. Althourh no other survey was conducted on a large scale in any of the target areas for this 
project, comparable findings serve as bxoad verifications of these data. Most recently, a city-wide survey conducted by the city's Office of Management and Budget in December, 1.978, did provide socio-economic information by planning district. St. Johns (HCD) and Portsmouth make up the bulk of planning district 1 while Richmond (HCD) and Creston comprise a little over half of planning district 3. The OMB study showed the same age clusters as reported here for all four neifhborhoods. Income levels were slightly higher, due to the inclusion of more upper income neighborhoods in the southeast district. Educational levels and ownership patterns were also close to those reported here (Ownership, North Portland: 80\%; Southeast: 72\%) (Portland, Oregon, Office of Management and Budget, 1978 in.p.).

The similarities in socio-economic charteristics reported in this chapter are important. They suggest that the differences in responses rerardin nelghborhood improvements and in satisfaction levels reported earlier may stem more from outside factors than from differences in the make-up of the four ne1 hborhood populations. However, the tendency toward higher education levels in Richmond (HCD) and the ase pattern differences between respondents in that neighborhood and Creston could have had some impact on peoples attitude toward their nei Đhborhood and their perceptions of ne Ighborhood change.

Footnotes for Chapter XI.

1. Only chi-square results which are significant at the .10 level or better are reported. 
CHAPTER XII

\section{SUMMARY AND CONCLUSIONS}

INTRODUCTION

The importance of neighborhoods in American society is not a mere academic matter. At stake is the nature of urhan Iife Itself (Piven and Cloward, 1970:122). Nelghborhood conditions are central in determining how people feel about the city they live in (Michelson, 1966. 355-360). A high quality neighborhood conveys a sense of well-being and satisfaction to its population in a number of ways. Fhysically, housing styles and conditions, landscaping, and available public facilities all count. Social elements inherent in the neighborhood's make-up such as the friendliness of one's neighbors or the ethnic, racial, or economic composition of the neighborhood, affect how a person feels about the neighborhood. Symbolic attributes such as the prestige of the neighborhood as reflected by housing prices and socioeconomic characteristics of the district's population affect attitudes as well. Can a local government help neighborhoods facing decay to achieve stability or must neighborhoods facing decay continue to confront it?

If the conclusions set forth in this study could be summarized in four sentences, they would be as follows first, the rehabilitation process developed by the city is highly successful. Second, neighborhood decline has been stemmed in the two loan nelghborhoods studied. 
Third, the loan programs in and of themselves have not changed people's attitudes toward their neighborhoods. Finally, the private sector has not perceived changes going on in the neighborhoods such that private policies toward the neighborhoods have themselves changed. The sections that follow expand on the conclusions that can be drawn from this study, in terms of process and impact.

\section{PROCESS EVALUATION}

Two basic types of evaluation were undertaken in this study process evaluation and program impact evaluation. With regard to process evaluation, the workings of the program itself were researched to discover whether the program runs smoothly, whether there were any gaps in Its set-up, and whether the recipients of the program were satisfied.

\section{A Smooth Program}

Portland's rehabilitation program does run smoothly. Program steps described in earlier chapters reflect a well-designed process through which loan recipients can apply for, receive, and use rehabilitation loans, on a larger scale, the actual implementation phases of the program, from choosing the HCD neighborhoods through loan evaluation, closely parallel the necessary steps for a successful rehabilitation program as outlined in Chapter III. Careful and detailed preplanning studies of the social and economic feasibility of rehabilitation were undertaken before any Portland neighborhoods were designated as Housing and Community Development areas. Affected residents were prepared for the program through a broad marketing effort led by the Portland Development Commission. Incomes and assets of likely candidates for the program were screened to ensure that loans could be repald without severe hardship when the time came to do so. Straight- 
forward financing was provided to homeowners, and technical assistance plus individualized counseling was available to homeowners throughout the loan process.

People who have received rehabilitation loans are satisfied with the Development Commission and its loan program. Even the people reporting trouble with contractors rated the program highly and would recommend it. Eighty-two percent of the loan recipients interviewed rated the loan program as excellent. The Portland Development Commission was also Eiven an excellent rating by $77 \%$ of the loan recipients.

Ferhaps the only process problems faced by the Comnission is how to keep closer track of the contractors who do not meet their azreements with the homeowners. Where people were unhappy with the loan process, it was invariably connected with some contractor problem. When potential loan recipients apply for loans, they are given a list of contractors who have performed rehabilitation work previously. A simple solution to the contractor problem might be to delete the names of companies or persons who have had a certain number of complaints registered ajainst their work, in addition to the complaint proceedings already set up by the Commission. Although the Fortland Development Commission has made some effort to do just that, such a process needs to be systematized. Or the agency might make a list of problem contractors and hand that list out to families new to the proßram.

PROGRAM IMPACT EVALUATION

The Recipients: Low and Moderate Income

One of the most difficult questions for analysts of government prograns to answer, and yet one central to program evaluation, is "who benefits?" The Housing and Community Development Act of 1974 provided a measurable objective in that it stated that HCD activities should give maximum feasible 
priority to activities which would benefit low and moderate income families or aid in the prevention of slums and blight (Nathan et al., 1978, 226). The Portland program seems to have done both to a large degree. Low income groups including divorced women and the elderly, often widowed, mostly received interest-free loans which helped them to insulate their homes and undertake structural improvements which aided them in bringing their homes up to the city's housing codes. Larger loans with low interest rates went to married couples of moderate income with children and older homes in need of repair. In a number of cases, these loans were piggybacked with PII loans so that people could refinance thelr homes or undertake major structural changes such as renovating their kitchens or bathrooms or adding rooms.

For all of the loans, people were reached who had no significant liquid assets with which they could have performed the work themselves, even thoush they seemed well able to afford their month-to-month housing costs. Fourteen percent of the recipients were receiving welfare, while a third received social security or a pension. Their homes were fast becoming obsolescent, one of the most obvious indicators of urban blight. The houses tended to be over fifty years old with less than a quarter of them built after 1935. Twothirds of the homes had been bullt between 1905 and 1935 with an average construction date of 1924. All this suggests that without the city's intervention, the housing would have continued to deterlorate--to everyone's dismay. The Neighborhoods: No Significant Attitude Changes

Far and away the predominant approach to community development under both the 1977 and 1974 acts has involved neighborhood conservation efforts designed to prevent urban decay (Dommell et al., 1978:228). For all these, Portland came first in the nation in its conservation efforts. In three years, $\$ 14.5$ million provided for the rehabilitation of over 3,000 housing 
units, meeting the city's goal of 1,00n units a year. Trice as many housing units were rehabilitated as the next highest city. As such, Portland provides an excellent model for other cities to follow in meeting the requirements of the Housing and Community Development Act of 1977. The Portland Development Commission's point system of discovering neighborhoods most likely to benefit from the program has proven to be accurate in that the program benefits low income groups who are on the verge of not being able to maintain their homes, in neighborhoods on the verge of decline.

Whether or not the number of units rehabilitated has stemmed urban decay or improved people's attitudes toward their neighborhoods is a more difficult question.

Regarding attitudes, Chapter I outlined four possible outcomes that could have stemmed from Housing and Community Development efforts. The first possibility was that persons living in Housing and Community Development neighborhoods would show higher levels of satisfaction with their neighborhoods than persons living in the control neighborhoods, whether or not they were home improvement loan recipients. Or even though HCD activities were taking place in Richmond and St. Johns, people were not aware of such actions suggesting that they would not show higher levels of satisfaction with their neighborhoods. A third possible outcome was that while people would perceive changes taking place in their neighborhoods, they would not show higher levels of satisfaction with their neighborhoods.

This study found differences in outcomes for the two Housing and Community Development neighborhoods. In St. Johns, the northern neighborhood, housing rehabilitation activities were combined with other public improvements. There residents did show more satisfaction with their neighborhood compared with the control neighborhood, Fortsmouth. 
For Richmond, on the other hand, even though residents were aware that rehabilitation efforts were taking place in the neighborhood, they do not show higher levels of satisfaction with their neighborhood than is true for Creston.

The difference in outcomes for the two HCD neighborhoods strongly suggests that it takes changes on a neighborhood level such as a new community center, rather than solely improvements on a personal level, for perceptions to change markedly. Such was the case in St. Johns.

\section{Neighborhood Decline Stemmed}

As for neighborhood decay, several things are clear. The loan neighborhoods have not show sizns of decline since the program started. Harket prices have not fallen, people are not leaving or expressing a wish to leave their neighborhoods because of physical decline. In Richmond (HCD), in fact, the loans may have promoted some displacement. Where St. Johns (HCD) has not experienced socio-economic changes as a consequence of the loan program, Richmond (HCD) does seem to be facing some changes in the make-up of its population suggesting an upgrading of the neighborhood. (Fourth possible outcome suggested in Chapter I.) The ratio of owners to renters has moved from approximately one renter for every homeowner to four homeowners for every renter in Richmond (HCD), while Creston has kept its one-to-one proportions. Throughout the survey, respondents in Richmond attested that the type of person moving into the neighborhood was changing, that more young couples were moving in. Education levels there are increasing, and so are incomes, as compared to Creston. The survey executed for the Neighborhood Livability Project in 1978 found that immigrators to Fortland tended to be young professionals, just starting on their careers. While their incomes tend to 
be lower than the city average, their education levels are high (Neir,hborhood Livability Project, 1978:11). It appears that Richmond is one of the inner-city neighborhoods such groups are choosinE for their homes.

For both HCD neighborhoods, more homeowners are improving their homes than would have otherwise. Moreover, the home improvements have been major, including insulation work, structural repair, wiring and plumbins work, and kitchen and bathroom remodeliñ. Residents feel that their neighborhoods are gettins better as a consequence. Residents of the loan neighborhoods are seein their neighbors fixing up their homes and feel positive about those improvements as well. People who live in the HCD nei $3 h b o r h o o d s$ say that their neishborhood has improved far more frequently than do residents of non-loan neizhborhoods.

Summarizing, thoush the loans themselves have not obviously improved general attitudes towards neighborhoods, they have led to increased perceptions of nei loan neizhborhoods saw their ow improvement efforts as having a biฐger Impact on the nelohborhood than did people living in the comparison nelishborhoods, Portsmouth and Creston. The loans are probably responsible for the socio-economic changes which are taking place in Richmond (HCD). Table XII offers a summary of the specific findings of the neir,hborhood survey 8

\section{TABLE XII}

\section{SUMMARY OI: SURVEY FINDINGS NEIJHBORHOOD SURVEY}

\section{Ioan related variables:}

a. $99 \%$ of all loan recipients recommend the programs. 
b. $82 \%$ rate the programs as excellent.

c. $71 \%$ rated $P D C$ as excellent.

d. Half rate the work done as excellent.

e. Without the loans, $65 \%$ of St. Johns recipients would not have worked on their homes (Richnond: 44\%)

f. Over half of the loan recipients needed to use their own finances to finish the work planned.

2. Socio-economic variables:

a. Monthly incomes, modal catezory St. Johns: $\$ 500-\$ 1,000$; Portsmouth: $\$ 500-\$ 1,000$, Richmond $\$ 1,000-\$ 1,500$; Creston: $\$ 500-\$ 1,000$.

b. Age groups : All neighborhoods had major clusters of 20 to 30 year olds and retired people. Creston has a larger proportion of elderly than Richmond.

c. Most residents of the four neighborhoods are married. The second highest marital category is "widow".

d. Family sizes are small for all the neighborhoods. Median size: 2 persons.

e. Education level, In St. Johns and Portsmouth, most people stopped at hizh school. The same holds for half of Richmond and Creston. Richmond spouses have higher education levels than in Creston.

f. Work status ? Percents of households with at least one person working full time: St. Johns: 71\%; Portsmouth: 53\%; Richmond: 71\%; Creston: 55\%.

g. Homeowners percents: St. Johns 74\%; Portsmouth 62\%; Richmond 82\%; Creston 69\%.

3. Housing and Neighborhood Varlables:

a. Feople have lived longer in St. Johns than in Portsmouth. $63 \%$ have IIved in St. Johns over five years compared to $54 \%$ for Portsmouth. Ilkewise, 55\% and 57\% of Richmond and Creston respectively have lived in their nelghborhoods over five years. The majority of respondents lived somewhere else in Portland before they moved to their present address.

b. The most frequently given reason for moving to a particular neighborhood was housing.

c. $82 \%$ of the respondents rated their neighborhood as very good or fairly good overall. St. Johns residents rated their neighborhood higher than Fortsmouth. Creston and Richmond ratings were the same.

d. Percentajes of persons perceiving their neighborhoods as improved since 1975; St. Johns 40\%; Portsmouth 13\%; Richmond 25\%; Creston 15\%.

e. Percentages of persons noticing specific improvements such as streets, houses, etc. 1 St. Johns $80 \%$; Fortsmouth $32 \%$ Richmond $54 \%$ Creston $24 \%$.

f. Percentages expecting to remain in neighborhood for at least five years : St. Johns 74\%; Portsmouth 60\%; Richmond 70\%; Creston 79\%. 
g. $88 \%$ of all respondents felt housing in their neighborhood was very well or fairly well kept up. Ioan neighborhoods tend to rate housing conditions slightly higher than nonloan neighborhoods.

h. Living in crowded conditions or older housing does not affect one's satisfaction level regarding his or her neishborhood.

1. Over $90 \%$ of the respondents are very or mostly satisfied with their own living quarters, even where there is heating or plumbing. Richmond and Creston show higher levels of satisfaction than Portsmouth and St. Johns.

j. Home improvements tend to be more substantial in the loan neighborhoods including insulation, outside structural improvements, roof and heating and plumbing code work. Non-loan neighborhood improvements were more cosmetic in nature.

4. Nelghbor Variables:

a. Respondents rate their neighbors highly regardless of how many they know or visit with.

b. The majority of people who improved their homes believe that their work affects their neizhbors positively and improves the neighborhood. Ioan neighborhood respondents felt this more strongly than did non-loan neishborhood respondents.

c. People divide fairly evenly between those who say alot of new people are moving in and those who do not.

5. Public Service Variables 8

a. Feople are generally satisfied with streets, police protection, and lizhts. St. Johns is not as satisfied with police or lights as Portsmouth, and Richmond is not as satisfied with lights as Creston.

b. Service improvements wanted most are street repairs. Social service programs, parks, home improvement projrams and utility and school improvements also ranked high.

PORTLAND'S FOAIS, MIXED SUCCESS

When Fortland developed its Housing and Community Development projram in 1975, it listed a central æoal of maintaining and improvin: the quality of its residential neighborhoods. Two avenues could be used to achieve that end. First, the goal could be achleved by creatin: and maintaining a growing inventory of safe and sanitary housing units at prices which households of all incomes could afford. Second, it 
could be achieved by awakening a sense of community pride among the residents of Portland's neighborhoods. The more specific central object of the Housing and Community Development Plan was to upgrade Portland neighborhoods facing possible decline through city assistance in rehabilitation efforts and through the encouragement of private investors to accept responsibility for rehabilitation.

By 1978, Portland had experienced mixed success in meeting its Housing and Community Development goal and objective. As the loan program stands, the city has gone far in assisting the major rehabilitation of housing. Possible abandonment in Housing and Community Development areas has been prevented. The quality of residential HCD neighborhoods has been maintained. On the nerative side, the city has not yet awakened an increased sense of community pride in the Richmond neighborhood suggesting that rehabilitation loans alone cannot maintain or improve the quality of Portland's neighborhoods by 1978, leavins the unresolved problem of maintainin: and expanding the impact of the city's rehabilitation efforts.

\section{Lack of Frivate Sector Follow-up}

Although the loan program was highly recommended, the lack of followup efforts on the part of the city leaves no guarantee that the rehab1l1tation efforts can be kept up. Further, since a solid percentage of recipients in Richmond and St. Johns stated that their loans were not sufficient enough to perform all the work needed, a second phase might be called for to ensure neighborhood stabilization. The city's prediction that the private sector would move into the neighborhoods has not materialized. Iending institutions, though aware of the programs and verbally cognizant of improvements taking place in the HCD neighborhoods, have not 
changed their policies toward those areas. Ioans have not increased thourh financial officers thought they had. Such maintenance efforts could prove to be difficult to establish publicly or privately. As they have little visibility, they are difficult to sell to private industry, and they have less political appeal than more flashy prograns (Ahlbrandt, $1978: 18)$

Portland still has almost 3,000 housing units which do not meet the city's minimum code requirements (Portland Development Commission, 1978:15). More, data reported by the city's Bureau of Planning in the City Planner Handbook recently, indicates that Portland's population is becomin less affluent, less Iikely to be homeowners, and more likely to live in smaller or one-person households. If that is true, the city's efforts at neizhborhood revitalization need to expand to more renter-oriented activities. Outside actors need to participate more actively. As Fatricia Harris has expressed it, "We cannot mobilize the critical mass of action basic to urban revitalization without partnership" (Harris, 1979,40).

There are no alternatives to an overall approach which embodies local govermments, the private sector, and private citizens (Ahlbrandt, 1977.68). Althourh more and more cities are earmarking community development funds for rehabilitation, nelohborhood revitalization is complex enoush so that there is also no altemative to an overall approach which deals not only with housing but physical improvements, crime, noise, schools, and traffic congestion. While any approach short of this may provide short run gains, the dynamics necessary for long-term stability may not be there, even where an individual program such as Portland's is obviously successful as far as it $\cong$ oes.

From the White House down, the revitalization of older urban neishborhoods has grown in importance as the nation has increasingly recognized 
their worth as a unique national resource and as the cost of replacing them with new neighborhoods escalated (Kaplan, 1978.5). Existing urban conditions call for increased rehabilitation efforts. Nearly half of all dwelling units in the United States were built before 1940. Those which have not been rehabilitated desperately need structural improvements to meet safety code requirements. Rising costs for new housing provide a further impetus for rehabilitation efforts, since most people have been priced out of the new housing market. Increasing enersy costs make it difficult to move outside of the city to find housing, putting additional pressure on existing housinz units as new housing production cannot be present demands.

Throush the Housing and Community Development Act of 1974, Congress transferred the major responsibility for the rehabilitation of housin: from the federal level to state and local governments. Yet, whereas a larse amount of investiration has been addressed to the problems of various lar:e scale rehabilitation projects, an extensive literature search unearthed no studies which gauged the effects to locally implemented rehabilitation projects on either program recipients or on the neighborhoods in which they live. This study has tried to fill both those voids. Strictly speakin:t, the findings set forth apply only to Eortland. However, in view of the fact that neishborhood decline has been experienced nationwide, it is likely that these findings could be used by other communities. Richard Nathan's 1977 study of the first year of the block झrant program found that nelzhborhood conservation was the most frequently used strategy for community development. Each of the fifty cities he studied could surely benefit from knowledze of Fortland's strategy and results. This study has shown Portland's loan process to be hifhly recommended by loan recipients. Although it takes lonrer than three years for private industry to pick up where government 
agencies leave off, the city's efforts provide a solid first step in developing a strong commitment to rebullding the parts of our city where such action is called for. But it is only a first step.

\section{RECOMMENDATIONS FOR FUTURE RESEARCH}

This evaluation provides some understanding of how one rehabilitation progxam has affected urban neighborhood decline. To establish that the consequences that have come from Portland's efforts do not reflect idiosyncracies in this city's make-up, comparable studies need to be undertaken in other communities where there has been a major emphasis on rehabila itation. Baltimore, Maryland, Washington, D.C., and Boston, Massachusetts are all possible places where case studies could be undertaken. In Portland, it is possible that three years of involvement with the Housine and Community Development Ioan program is too short a time period for the neighborhoods to have fully felt the impact of the loan program. Performing the neighborhood survey on a yearly basis, as a monitoring tool, could provide the c1ty with a more accurate appraisal of program outcomes. Results reported in this study could be used as baseline data which could be compared with later surveys. Such surveys could be especially useful for monitoring loan related changes in the control neighborhoods, Portsmouth and Creston, which are now HCD neighborhoods, of particular use would be the added insight such a monitoring system could offer on negative aspects of the program such as problems with particular contractors. At the same time, socio-economic changes taking place in the loan neighborhoods would be picked up. Attitude changes could be watched. To date, the city has no other unbiased method for evaluating the loan process or its impact. 
Real estate trends and private londing policlos need to be further studied both in Portland and elsewhere to better juage the scale of public efforts needed to trigger involvement by the private sector in urban rehabilitation efforts. Finally, if Portland should change its rehabilitation program in the future, repeating the neighborthood survey would allow the city to compace the effects of its new policy against findings reported here.
A successful city is a place that keeps sufficiently abreast of its problens so that it is not destroyed by them. Jane Jacobs 
CHAPTER XIII

EPILOGUE

In addressing the issue of future neighborhood decay and the case of Portland, it is necessary to note legislative trends and new urban settlement patterns which will provide the context for any policy impacts in the eighties, a context slighly different from that of 1975.

THE HOUSIN. AND COMMUNITY DEVELOPMENT ACT OF 1977

The Housing and Community Development Act of 1977 is a revision of the 1974 Act which created the Community Development Block irant program. The 1977 legislation still stresses activities which provide decent housing, a suitable living environment, and expanding economic opportunities, principally for persons of low and moderate income. There is one significant difference between the Acts, however. The 1977 Act concentrates more directly on revitalization, with its new Housin; Assistance Plan requirement that deteriorated housing units must be identified, that realistic, quantifiable joals for rehabilitated units must be set, and that the neighborhoods to be rehabilitated must be 1dentified. Table XIII shows that neighborhood-related programs worth billions of dollars are now going into nelghborhoods nationwide both through Housing and Community Development prosrams and others supported by the Department of Justice, ACTION, the Federal Home Loan Bank Board 
TABLE XLII

NEIGHBORHOOD RELATED URBAN POLICIES

Budget

Admin. Authority

Agency FY 1979*

Neizhborhood Revitalization (Direct Neighborhood Involvement)

1. Urban Volunteer Corps in ACTION

ACTION $\quad 40.0$

2. Neighborhood Self-Help Prozram

HUD

15.0

3. Livable Cities

HUD

20.0

4. Community Antio-Crime Programs

Justice

10.0

5. Troubled Schools

HEW

2.0

6. Community Development Credit Unions

CSAI

NCUA

12.0

CSA

20.0

7. Community Development Corporations

Nelohborhood Improvement (Local Sovernment Involvement)

1. Housinæ Rehabilitation

HUD $\quad 150.0$

2. Urban Parks and Recreation

HUD/

150.0

Interior

HEW

50.0

3. Health Centers

Special Programs

1. National Coop Bank

Indepen- $\quad 300.0-$ dent** $\quad 500.0$

2. Neighborhood Reinvestment Corporation

Indepen-

15.0

dent

3. Institute for Better Communities

FHLBB

* Dollars in Millions

** With Board appointed by President with advise and consent of the Senate

Source: Fracticing Flanner, September 1978 :p.8. 
and the Department of Health, Education, and Welfare.

\section{GENTRIFICATION}

By 1978, gentrification, or displacement, was becoming a much discussed issue in urban policy-making circles. Gentrification is the replacement of the original, lower class residents of a revitalized city neighborhood by a new class of affluent professionals (Cassidy, 1978 86). Increasingly it has become a problem central to the goal of rehabilitated urban neighborhoods nationwide. Paul joldberger in the New York Times (June 15, 1977) writes about the rehabilitation of brownstones and the conversion of warehouses, factories, and hotels which characterize urban renewal of the seventies. Such activities suggest an increase in demand of an affluent middle class for renovating older decaying neighborhoods with jood housing stock such as Philadelphia's Society Hill, Manhattan's Upper West Side, Brooklyn's Park Slope, and even New York City's Bedford-Stuyvesant. Some of the problem is the huge unmet demand for housing. A U.S. News and World Report article of May 8, 1978, titled, "The ireat American Apartment Squeeze of the 70's", found that the supply of apartments simply cannot keep up with demand. In that year, the apartment vacancy rate nationally was 5\%, the lowest since World War II. Present apartment projects are aimed at higher income groups, usually with no children or pets. Simultaneously, the supply of apartimints continues to dwindle as existing units are converted to condominiums. With rent hikes of up to $30 \%$ in the last year alone, increased competition for affordable housing means that certain neighborhoods face a possible wave of 
middle class buyers (Iross, $1978.5 ;$ Morrison, 1977:203). The question of protecting the ability of lower income residents to remain in physically upgraded housing units and neighborhoods has thus become a central issue confronting local governments. As the former Secretary of the Department of Housing and Urban Development, Patricia Harris, recently stated:

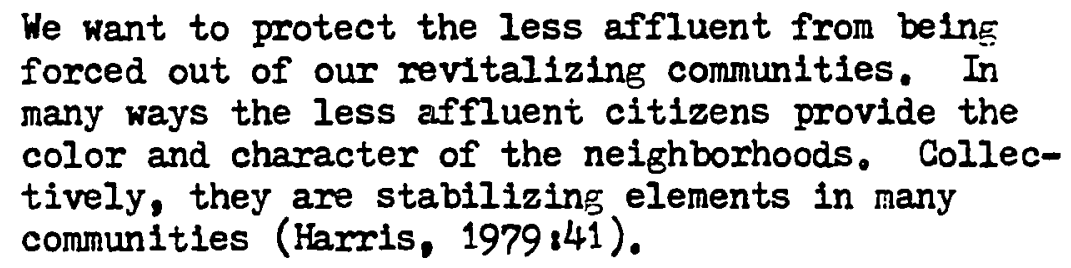

In Fortland, signs of gentrification can be seen in Richmond (HCD), the HCD neirhborhood closest to downtown. With rising eneryy costs and some availability of reasonably priced housing, the threat of further displacement is very real. The ability of low-income residents to remain in their physically upgraded housing units needs to be protected.

In a way, the neighborhood may already have found a partial solution. Its neighborhood association, workine on the city's comprehensive plan, was the only neighborhood group in Portland which called for more public housing in the neighborhood to make up for increased housin? costs, Other tools are available for the city to consider. Spreading out housint demand to more neirhborhoods could take some of the pressure off of Richmond (HCD). The cities of Boston and Seattle have already developed "marketing" programs to encourage reinvestment in neighborhoods which are not experiencing relnvestment (Shanahan and Joseph, 1978:20).

There are other options open to Fortland. In Washington, D.C., 
tenants have the right of first refusal on the sale of the building in which the tenant resides. The tenants are guaranteed 45 days to reach a decision before the owner can offer the property to anyone else. The tenants can use the month and a half to raise the necessary financing. Iandlords who violate the law are subject to fines and can be sued by the tenants.

Other local legislation might alleviate some of Fortland's possible displacement problems. Both New York City and Washington, D.C., have passed legislation to limit the conversion of certain apartment buildings to condomintums. Finally, local tax relief proミrams can help families remain in their homes in nelghborhoods which might be experiencing rapid and substantial increases in property taxes due to revitalization. Finally, tax rebates could be provided whenever the property tax exceeds a certain percent of increase for elderly and low-income homeowners (Housing and Urban Development, 1979, 1-2). 
BIBLIOGRAPHY 
SOURCES CONSULTED

Aberbach, J.0. and J.L. Halker (1972). "Citizen Desires, Policy Outcomes and Community Control". Urban Affairs Quarterly (September), 55-75.

Abrams, Charles (1965). The C1ty is the Frontier. New York: Harper and Row.

Ahlbrandt, Roger S, Brophy, Paul D, and Farkas, William (1974). "Current Issues Explored", Journal of Housing (January), 11-14.

Ahlbrandt, R.S. (1977). "Exploratory Research on the Redlining Thenomenon", Journal of American Real Estate and Urban Economic Association, (Winter) 473-481.

Ahlbrandt, Roger, and Margaret Charny and James Cunningham (1977).

"Citizen Perceptions of Their Neighborhoods", Journal of Housin., . (July) 338-345.

Ahlbrant, Rober S. (1978). "Home Maintenance Programs: Are they a Necessary Ingredient for Neloghborhood Preservation?", Practicing Planner, (September) 18-22.

Anderson, Martin (1964). The Federal Bulldozer, Cambridse: M.I.T. Press.

Anton, Thomas J. and Bruce Bowen (1976). "Toward a Clarification of Citizen Satisfaction with Metropolitan Services", Paper presented at the annual meeting of the American Political Sclence Association, Chicago, Ml. (September) 2-5.

Appleyard, Donald and Mark Intell (1972). "The Environmental Quality of City Streets: The Residents" Viewpoints", Joumal of the American Institute of Flanners, (July) 84-101.

Appleyard, Don (1977). "A Planners Juide to Environmental Psychology", Journal of the American Institute of Flanners, (April), 184-189.

Babbic, Barl R. (1973). Survey Research Methods. Belmont, Californial Wadsworth Publishing Co., Inc.

Bagby, D. Tordon (1973). Housing Rehabllitation Costs, New York 1 D.C. Heath. 
Baroni, Geno and Karen Kollias (1978). "Neighborhood Reinvestment", HUD, Challenge, , (January ) 16-19.

Berger, Curtis; Goldstein, Eli; and Rothrauff, Guido A. (1969). "SIum Area Rehabilitation of Private Enterprise". The Columbia Law Revier, (May) 739-769.

Blalock, Hubert M. (1972). Social Statistics. 2nd Edition. New York : McGraw-Hill Book Company.

Boulding, Kenneth E. (1962). "Social Justice in Social Dynamics", in Brandt Richard, ed. Social Justice, Englewood Cliffs, New Jersey: Prentice Hall, Inc.

Bryce, Harrington (1973). "Identifying Socio-Economic Differences between High and Low Income Metropolitan Areas" SocioEconomic Planning Science, (July) 709-712.

Buttimer, Ann (1972). "Social Space and the Planning of Residential Areas," Environment and Behavior, (September) 279-318.

Campiell, Donald T. and Ross, H. Lawrence (1970). "The Connecticut Crackdown on Speeding Time - Series Data in Quasi-Experimental Analysis", in Tufte, Edward. The Quantitative Analysis of Social Problems.

Capron, W. M. (1969). "The Impact of Analysis on Bargaining in Govermment", in J. W. Davis (ed), Politics, Programs, and Budgets, Englewood Cliffs, N.J.: Prentice Hall, 250-260.

Carmon, Naomi (1976). "The Social Planning of Housing", Journal of Social Policy, (January) 49-59.

Carnegle, Christa Iew (1972). "Multiple Housing Programs and Urban Housing Policy". Journal of the American Insitute of Planners, XXXVIII, (May) $160-167$.

Case, Frederick E. (1968). "Code Enforcement in Urban Renewal", Urban Studies, (November) 277-281.

Cassidy, Robert (1978). "Can Success Kill A Nelghborhood?", Planning. 6-7.

Center for Community Change, Pennsylvania Department of Community Affairs (1978). Annotated Bibliography on Housing Rehabilitation, (May) Harrisburg, Pa. 17120

Christian Science Monitor Reprint (1978). "A Nation of Neighborhoods", C.S. Publishing, Box 125, Astor Station, Boston, Mass. 02123.

Chung, Hyung C. (1973). The Economics of Residential Rehabilitation, Social Iife of Housing in Harlem. New Yorks Praeger. 
Cicarel11, Janes and Clifford Ianders (1972). "The Cost of Housing for the Poor, A Case Study", Iand Economics, 53-57.

Cochran, William G. (1963). Sampling Techniques, New Yorks Wiley.

Cogen, Holt, and Assoclates (1975). Housing and Iocal Government: An Evaluation of Policy Related Research in the Field of Municlpal Housing Services, New Haven, Connecticut , Cogan, Holt, and Associates.

Congressional Quarterly Incorporated (1974). Congressional Quarterlys 1974 Almanac, Washington, D.C. I Congressional Quarterly, Inc.

Corning, Howard McKinley (1947). Willamettc Iandings, Portland Bindords and Mort.

Danels, Mark (1978). "When Mortgage Money Disappears, the Neighborhood Joes With It", Empire State Report, (March - April), 5 - 13.

Day and Underwood (1974). Quantitative Analysis, 3rd ed. Englewood Cliffs: Prentice Hall, Inc.

Denver, Colorado, Office of Policy Analysis (1977). Rental Housing Investments in the Inner C1ty, September, Denver, Colorado.

Denzin, Norman K. (1970). Sociological Methods: A Source Book, Chicaso: Aldene Publishing Company.

DeSalvo, Joseph (1973). Rationale for Jovernment Intervention in Housing Housing as a Merit jood. Study paper for the National Housing Folicy Review, Department of Housing and Urban Development, Washington, D.C.: Sovernment Printing Office.

DeSalvo, Joseph (1974). "Nelghborhood Upgrading Effects of Middle Income Housing. Projects in New York City". Journal of Urban Economy, (July) 269-277.

Devine, Richard J.: Rennie, Winston; and Sims, N. Brenda (1973). "Where the Iender Looks First A Case Study of the Mortgaje Disinvestment in Bronx County, 1960-1970", New York : National Urban League.

Di Domenico, Anita (1978). "Equalizing Housing Opportunities in Chicago", HUD Challenge, (January), 12-13.

Dietz, Stephan and Yates, John (1973). "Ability to Afford Decent Housing". Study Paper for the National Housing Policy Review, Department of Housing and Urban Development. Washington D.C., Tovernment Printing Office. 
Downs, Anthony, ed. (1970). Urban Problems and Frospects. Chicaro Markham Publishing Company.

Downs, Anthony (1972). "Are Subsidies the Best Answer for Housing Low and Moderate Income Households?", The Urban Laryer, (Summer) 405-416.

Durand, Roger and Eckhart, Dennis R. (1973). "Social Rank, Residential Effects, and Community Satisfaction", Social Forces, (September) 74-85.

Elazar, Daniel (1976). "Restructuring Federal Housing Programs: Who Stands To Jain?", Publius, (Spring) 75-94.

Embry, Robert C. (1979). "U.S. Urban Policy", Journal of Housing, (Fe bruary), 99-100.

Ericson, William A (1968). "Optimism Stratified and Multi-Stage Sample Using Prior Information", Journal of the American Statistical Association, 964-983.

Fainstein, Susan S, and Fainstein, Norman I (1972). The View From Below: Urban Politics and Social Pollcy., Bostons Little, Brown. and Company.

Fellman, Jordon and Brandt, Barbara (1970). "A Nel hhborhood a Highway Would Destroy", Environment and Behavior, 281-301.

Fre j, William and Sprecht, Harry (1976). "The Housing and Community Development Act of 19748 Implications for Policy and Plannins", Social Science Review, (June) 275-292.

Fried, Edward and Rivlin, Alice (1973). Setting National Priorities : The 1974 Budget . Washington, D.C.1 The Urban Institute.

Frieden, Bernard (1964). The Future of Old Neighborhoods: Rebuildin for a Changing Population . Cambridze, Harvard, M.I.Ti Joint Center for Urban Studies.

Frieden, Bernard and Kaplan, Marshall (1975). The Pollitics of Nezlect: Urban Aid from Model Cities to Revenue Sharing. Cambridge: M.I.T. Press.

Friedman, Ralph (1979). "Population irowth Staggers Orezon", Community Press, March 28.

Fal braith, Kathy, Larkin, Geri; Sawyer, Chris; Spencer, Robert; and Steidel, Yaeko (1975). "The Housing and Community Development Act of 1974", Portland, Oregon! Fortland State University School of Urban Affairs.

jale, Dennis (1978). "Dislocation of Residents", Journal of Housinz, (May) 232-238. 
Saston, Joseph (1911). Portland, Oregon, Its History and Builders, Vol. 1, 2. Portlandi S.J. Glarke Publishing Co.

Soldfield, David R. (1976). "The Ifilts of Suburban Growth The Washington, D.C. SMSA", Urban Affairs Quarterly,

(September) 83-102.

Solledge, Reginald 3 . and Zannaras, Georgia (1973). "Cognitive

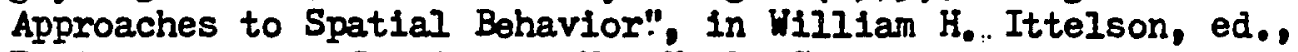
Environment and Cognition, New York Seminar Press.

ireenstein, Abraham J (1971). "Local Community's Stake in Code Enforcement". The Urban Lawyer, (Fall) 601-608.

Ireenstein, Abraham J (1971). "Federally Assisted Code Enforcement : Probiems and Approaches", The Urban Lawyer, (Fall) 629-642.

Ireer, Scott (1965). Urban Renewal and American C1ties. New York: Bobbs and Merrill.

Irethen, D.M. and Miezkowski, Peter (1974). "Determinants of Real Estate Values". Journal of Urban Economics, (April) 60-67.

Iross, Ema (1978). "Notes for Gentrification Study", Unpublished Report Ann Arbor, Michigan, University of Michigan, Institute for Fublic Policy Studies.

Irubb, Edward; D. James Manning; and William A. Manning (1974). "The Nine Clusters that are Portland". Portland Commerce Marazine, (February) 20-25.

Imuen, Nina J (1976). "Will Consumer Demands Continue to Influence Residential Development?", Urban Land, (October) 10-13.

Haar, Charles M (1975). Between the Idea and the Reality: A Study in the Origin, Fate, and Iegacy of the Model Cities Program. Boston: Little, Brown and Company.

Harris, Patricla (1979). "Successful Housing Policies Depend on Meshing Private Investment and Public Expenditure", Journal of Housing, (January), 40-42.

Hartman, Chester W (1963). "Social Value and Housing Orientations", Journal of Social Issues, (April), 113-131.

Hartman, Chester W (1975). Housing and Social Policy. Englewood Cliffs, New Jersey : Prentice-Hall, Inc.

Hatry, H. Bo, R. E. Winnie, and D. M. Fisk (1973). Practical Pro-ram Evaluation for State and Jocal ievernment. Washington, D.C.8 Urban Institute. 
Haveman, Robert and Burton Wasbrod (1977). "Defining Benefits of Pablic Programs. Gome Suidance for Policy Analysts". Folicy Analysts, (Winter) 169-197.

Hermann, John 3. (1979). "Public-Private Partnership is the key to Urban Development Program Accomplishments", Journal of Housini, (September) $42-44$.

Hinkley, Katharine (1977). "The Bang and the Whimpers Model Cities and Thetto Opinion", Urban Affairs Quarterly. (December) $131-450$.

Hoffman, Bernard, Jr. (1969). "Housing Demand Characteristics of Underhoused Families in the Inner City". The Annals of Rerlonal Sclence, (December) 15-26.

Hoover, Kerry (1977). "The Poor and Elderly will Hear the Brunt, Fortland's Housing Policy", Portland Today, (December) 3-5.

Hous in: and Home Finance Agency (1962). 16th Annual Report. Washington, D.C., Housing and Home Finance Agency.

Hughes, James (1975). Urban Homesteaging, New Brunswick, N.J.I Ruterers University.

Imbriano, Robert (1977). "Home Ownership a Iuxury? Housing Costs are Spiraling Faster than the Averare Income, Making Home Ornership More and More Difficult", Black Enterprise, (Ausust) 3!-33.

Jacobs, Jane (1961). The Death and Iife of jreat American Cities, New York City, Random House, Inc.

Jones, Bryan D. (1978). "Urban Policy and the Distribution of Public Services: Problems and Prospects", delivered at Midwest Political Science Association, Chicazo, Ill., (April) 20-22.

Kaptur, Marcia (1978). "Neichborhoods and Urban Policy I The View from the White House", Fracticin- Planner, (September) $5-8$.

Kasl, Stanislav and Harburg, Emest (1972). "Perceptions of the Neizhborhood and Desire to Move Out". Journal of the American Institute of Planners, (September) 318-324.

Katz, D.: B. Jutek, R. Kahn; and E. Barton (1975). Bureaucratic Encounters: A Pilot Study in the Evaluation of Government Services, Ann Arbor: Institute for Social Research.

Keating, Dennis, and Lejates, Richard (1978). "Who should benefit from the Community Development Block Irant Program?", The Urban Lawyer, (Fall) 701-737. 
Ke1th, Nathaniael (1973). Politics and the Housing Grisis since 1930. New Yorks Universe.

Keller, Suranne (1968). The Urban Neighborhood. New Yorks Random House:

Keyes, Iangley C (1969). The Rehabilitation Flanning Jame : A Study in the Diversity of Neighborthood. Cambridge 8 H.I.T. Press.

Kim, Jae-on and Kohout, Frank (1970). Analysis of Variance and Covariance: Subprograms Anova and One-way ", in Statistical Package for the Social Science. Second Ddition, Mcisraw Hill, Inc.

Kitchen, Judith and Simmons, David (1977). "Ne1ghborhood Preservations", Cities and Viliages, (October) 8-11.

Kornhauser, Arthur (1952). Detrolt as the People See It, A Survey of Attitudes in an Industrial City. Detroit, Wayne University Press.

Krlstoff, Frank S. (1973). The Federal Role in Rehabilitation and Neizhborhood Preservation. Study paper for the National Housinz Policy Review. Department of Housing and Urban Development. Washintton, DC, sovernment Printin; Office.

Landsing, John B. and Robert W. Maran (1969). "Evaluation of Neighborhood Quality", Journal of the American Institute of Politics, (May), $195-199$.

Landsing, John $B_{\xi}$ Stephen B. Withey; and Arthur C. Wolfe (1971). Working Papers on Survey Research in Poverty Areas. Ann Arbor, Michigan : University of Michigan Press.

Leven, Charles L; Little, James T; Nourse, Hugh $D_{;}$and Read, R. B. (1976). Ne1 zhborthood Change, Lessons in the Drnamics of Urban Decay. New York 8 Praeger.

Levin, Melvin R, ed (1969). Innovations in Hous ins Rehabilitation. Bostons Boston University.

Loshbough, Bernard E (1967). "Rehabilitation of Housing I Federal Frozrans and Private Enterprise", Law and Contemporary Problems, (Summer) 416-438.

Iinton, Mields and Coston, Inc. (1973). Scattered is Concentrated Housing Rehabilitation, National Housing Policy Review, Washington D.C.: Fovernment Printing Office.

Listokin, David (1972). The Dymamics of Housing Rehabilitation : Macro and Micro Analyses, New Brunsw1ck, New Jorsey Center for Urban Policy Research, Rutgers University. 
Iovrich, Nicholas and Taylor, 3. Thomas (1976). "Neighborhood Ivaluation of Iocal Sovernment Services \& A Citizen Survey Approach", Urban Affairs Quarterly, (December) 197-222.

Lycan, Richard; Pete Pendleton; and James Weiss. (1978). Residential Mobility: Study for Portland, Oregon. Center for Population Research and Census, Portland State University, Portland, crezon.

MacColl, E. Kimbark (1975). The Shaping of a City: Business and Politics in Portland, Oreson 1885-1915. Portland Jeorsian Press Co.

McFarland, M. Carter, and Vivrett, Walter $\mathrm{K}$, eds, (1965). Residential Rehabilitation. Minneapolis : University of Minnesota Press.

McFarland, M. Carter (1973). Standards for Residential Rehabilitation. Study Faper for the National Housins Policy Review, Department of Housinx and Urban Development, Washinzton, D.C.: Jovernment Printin; Office.

McKeown, Jarces and Frederick Tietze (1971). The Changing Metropolis. Boston: Hourhton Mifflin Company.

Marcuse, Feter (1969). "Comparative Analyses of Federally-Aided Low and Moderate Income Housinz Programs", Journal of Housin-e (October), 536-539.

Marcuse Peter (1971). "Social Indicators and Housing Policy", Urban Affairs Quarterly, (December) 193-218.

Meadows, Jeorge Richard and Stephen T. Call (1978). "Combining Hous in: Market Trends and Resident Attitudes in Plannin Urban Revitalization", Journal of the American Institute of Planners, (July), 297-305.

Menath, Michael (1979). Fersonal Interview, Portland, Orezon. April 20,1978 .

Mendelson, Robert and Quinn, Michael A (1976). The Politics of Housin: in Older Urban Areas. New York : Praeger.

Michelson, William (1966). "An Emplrical Analysis of Urban Environmental Preferences", Jourmal of the American Institute of Manners, (November), 355-360.

Morris, Milton D. ('976). New Federalism and Community Jevelopment: a Preliminary Evaluation of the Hous in ; and Community Development Act of 1974, Cambrid re, Harvard, M.I.T., Joint Center for Dolitical Studies.

Morrison, Peter (1977). "Demorraphic Trends that will shape Future Housins Demands", Policy Science, 208-215. 
Musfrave, Richard A (1973). Pollcies of Housinj Support Rationale and Instruments. Study paper for National Housin; Policy Review Study Papers, Washinrton, D.C, : Jovernment Printin:; Office.

Nathan, Richard; Dommel Faul; Ilebschutz, Sarah, and Morris, Milton (1977). Monitoring the Block irant Progran for Community Development Political Science Quarterly, (October) 219-244.

Niebanck, Paul and Pope, John (1968). Residential Rehabilitation, The Pitfalls of Non-Profit Sponsorship. Philadelphia, Fennsylvania! University of Pennsylvania Institute for Environmental Studies.

Cakland, William H. (1973). A Rationale for Federal jovernment Intervention in Housing Distortions Arising from Present Fiscal Arranjements of the Iocal jovermment Level. Study Paper for the National Housing Policy Review, Department of Housinj and Urban Development, Washinjton, D.C.: Government Printinæ Office.

Orejon Attitudes, Inc. (1978). Measuring Citizens' Perceptions of Easic City Services. Portland, Ore;on.

Nenno, Nary K (1978). "The 10-year Housing .30ais". The Joumal of Housing, (July), 342-346.

Oster, Sharon M; Lake, Elizabeth E; and Oksman, Conchita Jene (1978). The Definition and Measurement of Foverty. Volume 1, A Review. Boulder, Colorado: Westview Press, Inc.

Paulson, R. A. The Transformation at 39th and Powell. The Community Press. Neighborhood History Project File.

Peterson, Jeorre (1967). "A Model of Preference, Quantitative Analyses of the Perceptions of the Visual Appearances of Residential Neizhborhoods", Journal of Rexional Science, (Summer), 19-33.

Phillips, Kenneth F., and Bayson, Davie Z (1971). "Refinancings A First Step Toward a Realistic Housins Program for the Poor". Jeorze Hashinzton Iaw Review, 835-869.

Piven, Frances Fox and Cloward, Richard A (1972). Regulatinj the Poor The Functions of Public Relief. New York: Random House.

Porter, Paul R. (1976). The Recovery of American Cities. Denver, Colorado: The Two Continents Publishing Group, Ltd.

Portland, Oreson, Bureau of Management and Budzet (1979). City-wide Service Delivery Joals and Objectives Project, (January). Portland, Oregon.

Portland, Orezon, Bureau of Manazement and Budget (1979). City-Wide Service Delivery Joals and Objectives Project, Proposed Joals. (February). 
Portland, Orezon, Bureau of Flanning (1977). The City Flanner's Handbook, (November).

Portland, Oregon, Bureau of Planning (1978). Community Development Plan, (December).

Portland, Orezon, Bureau of Flanning (1978). Potential Historic Conservation Districts in Inventory of Historic Resources, (October).

Portland, Orezon, Housing Task Force (1977). Proposed Housing Policy for Portland, (December).

Portland, Oregon, Neighborhood History Projeot (No Date iiven). Portsmouth and University Park, File Articles.

Portland, Orezon, Ne1jhborhood Itvability Project. (1978). Phase II Report: Implementation (December).

Portland, Oregon, Office of Planning and Development (1975). Community Development Block irant Plan.

Portland, Oreson, Office of Flanning and Development and the Portland Development Commission (1978). Housing and Community Development Fourth Year Sumnary, (February).

Portland, Oregon, Office of Planning and Development (1978). Policy and Research Section, Housing Market Analysis and Data Summary for the City of Portiand, (September).

Portland, Orejon, Portland Development Commission (1976). Rehabilitation: A Community Development Program, (May).

Portland, Oregon, Portland Development Commission (1976). Rehabilitation Cookbook, (December).

Portland, Orezon, Portland Development Commission (1977). Memorandum From F.R. Bowman to Field Services Staff, (May 6).

Portland, Oreson, Portland Development Commission (1977). Memorandum from F.R. Bowman to Field Services Staff, (August 15).

Portland, Oreron, Portland Development Commission (1977). Project Fleld Services Marketing Manual, (June).

Portland, Oreron, Portland Development Commission (1978). Completing the Second Decade: Progress Report, (September).

Portland, Orezon, Portland Development Commission (1978). Housing Assistance Prozrams, (March). 
Portland, Oreron, Portland Development Commission (1979). Southeast Uplift Office Memorandum, (February 2 ).

Portland, Oreron, Portland Planning Commission (1975). City's Pollcy Statement.

Powledge, Fred (1970). Model City. New Yorks Simon and Schuster.

Purdy, Ruby Fay (1947). The Rose City of the World. Portland: Binfords and Mort.

Rand Corporation, (1955). A Mililon Random Digits with 100,000 Normal Deviates. Jlencoe, IIl.: Free Press.

Ranney, Austin, ed.. (1968). Political Science and Public Folicy, Chicago: Marikham.

Richman, Alan and Chapin, F. Stuart Jr. (1977). "A Review of the Social and Physical Concepts of the Neichborhood as a Basis for Flanning Residential Environment, Chapel Hill, University of North Carolina, Department of City and Rerional Planning, (January).

Roestacher, EIizabeth A and Joodman, John L. (1976). "Race and Home Omership: Is Discrimination Disappearing?", Economic Inguiry, 14, (March), 59-70.

Rothenberg, Jerome (1973). A Rationale for jovernment Intervention in Housing: The Bxternalities ienerated by jood Housinj. Study Paper for the National Housing Policy Review, Department of Housin; and Urban Development, Washington, D.C, I Jovernment Frintinx. Office.

Saffran, Bernard (1976). The Appropriate Role of jovermment in Housins, in U.S. Department of Housing and Urban Development Housing in the Seventies: Working Papers, Washington, D.C', J Jovernment Printing Office.

St. Johns History Froup. St, Johns History, Bicentennial 1st Edition, (No Date iiven) (No Publishins Information ilven).

Schaaf, A. H. (1969). "Economic Feasibility Analysis for Urban Renewal Housing Rehabilitation". Journal of the American Institute of Planners, (November), 399-404.

Schmandt, Henry $J$ and Warner Bloomberg Jr. (1969). The Muality of Urban Iife, Vol. 3, Urban Affairs Annual Reviek. Sare: Beverly Hills, Califormia.

Schwartz, Ted (1970). "Iow Income Housing Headaches Overcome", Nation's Cities, (October) 19-23. 
Semer, Milton; Julian Zimmerman, Ashley Ford, and John Frantz (1976). A Reveiw of Federal Subsidized Housing Fororams in U.S. Department of Housing and Urban Development, Housing in the Seventies: Workin Papers. Washington, D.C.1 iovernment Printing Office.

Shuman, Howard, E (1968). "The Role of Hous in = Code Enforcement in Meetin: the Housing Needs of the Low-Income Family". Journal of Housing, (December) 568-570.

Sternlieb, Jeorse; Burchell, Robert , Hughs, James; and James, Franklin (1974). "Housing Abandonment in the Urban Core". Joumal of the American Institute of Planners, 321-335.

Sudman, Seymour (1976). Applied Samplinz. New York, New York Academic Fress.

Staehli, Alfred (1975). Preservation Options for Portland Neighborhoods: A Report on the History of Portland's Neizhborhoods and their Historic Centers. Prepared for the 1974 City Options Projram of the National Endowment for the Arts: Portland, Bureau of Plannin?.

Stejman, Michael ( $\left.{ }^{4} 972\right)$. Housin- Investment in the Inner City: The Dynamics of Decline; a Study of Baltimore, Maryland; 1968-1970. Cambridre, Mass. 1 The Massachusetts Institute of Technoloyy Press.

Sterman, Michael (1973). "Iow-Income Ownership: Exploltation and Opportunity", Journal of Urban Law, (Febrary), $37^{1-402 . ~}$

Struyk, Rayment ( 1977 ). "Need for Local Flexibility in U.S. Housing Policy". Pollcy Analysis, (Fall), 47!-483.

Sudman, Seymour (1976). Applied_Samplinz New York, New York \& Academic Press.

Taeuber, Karl E. and Taeuber, Alma F (1969). Nerroes in Cities Residential Serrezation and Neirhborhood Change. New York \& Atheneur.

Tazp̣art, Robert III (1970). Low-Income Housing, A Critique of Federal Aid. Baltimore: The Johns Hopkins University Press.

Taylor, 3. T. (1974). "Citizen Evaluation Surveys, Link Between Opinion and Policy", National Civic Review, (December) 577-581.

Teplitz, Paul (1973). Forecasting Metropolitan Housing Needs. Cambridje : M.I.T. Press.

U.S. Bureau of Census, Census Population and Housin Tracts, Final Report, PHC (1), 165, Portland, Oreson, Washington SMSA. 
U.S. Bureau of the Census. Statistical Abstract of the United States (1977). 98th edition, Washington, D.C. Table 759. Purchasing Power of the Dollar, ${ }^{1940 ~-~} 1977$.

United States Commission on Civil Rights (1974). Nortraze Money who iets It? Hashington, D.C.: Jovernment Printing Office.

U.S. Congress Budget Office (1977). Homeownerships The Chanzing Relationship of Costs and Incomes and rossible Federal Roles, (January), Washinston, D.C.: jovernment Printin? Office.

U.S. Congress (1976). United States Statutes Iaxge. 93rd Congress, 2nd Session, Vol. 88, Part 1, Washinzton, D.C. 8 jovernment Irinting Office.

U.S. Congress, House Subcommittee on Housin $;$ of the Committee on Bankin and Currency, Hearin?s: Demonstration Cities, Housing and Urban Development, and Urban Mass Transit. 89th Congress, 2nd Session, 1966, Part 1.

U.S. Department of Housing and Urban Development (9967). Rehabilitation Prosrams. A Report to the Subcommittee on Housin: and Urban Affairs of the Committee on Bankin and Currency, U.S. Senate, Washin ton, D.C., Jovernment Printins Office.

U,S. Department of Housing and Urban Development (1970). FHA Techniques of Housin- Market Analysis. Washington, D.C.8 Government Frintin: Office.

U.S. Department of Housing and Urban Development (1974). Internal Correspondence, Office of the Secretary for Policy Development and Research, Washington, D.C.. (April).

U.S. Department of Housin - and Urban Development (1974). Intermal Correspondence, Office of the Assistant Secretary for Policy Development and Research, Washington, D.C.. (April).

U.S. Department of Housinx and Urban Development, National Housing Folicy (1976). Housin: in the Seventies: Working Papers. Washin D.C. 8 Tovermment Printing Office.

U.S. Department of Housinj and Urban Development, Office of Nei-hborhoods, Voluntary Associations, and Consumer Frotection (1979). Consumer Bulletin (April).

U.S. Department of Housing and Urban Development (No Date Iiven). A juide to Housing Rehabilitation Prorrams.

Urban Renewal Administration (1962). Urban Renewal Project Characteristics. Washin:ton, D.C.

Warren, Donald (1977). "The Functional Diversity of Urban Neighborhoods". Urban Affairs Quarterly,

(December). 151-180. 
Webb, Kenneth and Hatry, Harry (1973). Obtaining Citizen Feedbacks The Application of Citizen Surveys to Local jovernments. Washington, D.C.: The Urban Institute.

Weicher, John C (1972). Urban Renewal, National Prorram for Local Problems, Washinxton, D.C.1 American Enterprise Institute for Public Policy Research.

Weicher, John C (1976). "The Rationales for iovernmental Intervention in Housing: An Overview", in U.S. Department of Housing and Urban Development, National Housing Folicy Review, Housinz in the Seventies: Workin. Papers. Washin rton, D.C.: iovernment Frintin- Office.

Weiler, Conrad (1978). Achieving Social and Economic Diversity in Inner City Ne1-hborhoods Through Increased Demand for City Housinby Middle Income Persons. Paper Presented at Fifth Annual Back to the City Conference, October 5-8.

Welfeld, Irving (1977). "American Housin Folicys Reverse Fro:rams by Prudent People", Public Interest, (Summer), 128-144.

Wexler, Harry J. and Peck, Richard (1975). Housing and Local :overnment: A Research iulde for Policy Makers and Ylanners. New York : Lexington Books.

Whitbread, Michael (1978). "Two Trade-Off Experiments to Evaluate the Quality of Residential Environments", Urban Studies, (June) $149-166$.

White, Louise A. (1979). "Approaches to Land Use Policy", Journal of the American Plannint Association. (January) 62-71.

Wilkinson, R.K. (1973). "Housin? Prices and the Measurement of Externalities", Economic Journal, (March) 72-86.

Wilson, James Q., ed, (1966). Urban Renewal, The Record and the Controversy. Cambridges M.I.T. Press.

Wilson, Robert I. (1962). "Livability of the City! Attitudes and Urban Development", F. Stuart Chapin Jr. and Stanley F. Weiss, (eds), Urban irowth Dynamics in a Re:ional Cluster of Cities. New York \& John Wiley.

Wolman, Harold (1971). Politics of Federal Housin-. New Yorks Dodd, Mead, and Company.

Wolpert, Julian (1972). Metropolitan Neighborhoods : Participation and Conflict Over Change. Commission on College ieo-raphy, Resource Faper \#16. Association of American jeo rraphers, Washintton, D.C., 1972. 
187

Worthy, William (1976). The Rape of Our Neighborhoods : And How Communities are Resisting: Take-Cvers by Colleges, Hospitals, Churches, Businesses, and Public Arencies. New York: William Sorrow and Company, Inc.

Yin, Robert (1977). "What a National Commission on Neighborhoods Could Do". Journal of the American Real Estate and Urban Economics Associations, (Fall), 255-279.

Young, M. and Willmott, Peter (1957). Family and Kinship in East London. London: Rutledge and Kegan Paul.

Zellner, Arnold, (1971). An Introduction to Bayesian Inference in Econometrics, New York John Wiley. 
APPENDICES 
APPENDIX AI CODING FOR THE PORTLAND DEVELOPMENT COMMISSION FIIE DATA 
Some comments should be made about how the PDC information was coded so it could be analyzed, $1, e .$, how some of the descriptive variables were transformed tnto numerical codes and how some of the numeric variables were broken down into categories for tables. First, the ID number for each file was simply the random number given to a reciplent's file. Loan types were given numeral 1 through 4 where DPL loans $=1$, HCD-3 loans $=2,312$ loans $=3$, and PII loans $=4$. Census tracts were stralghtforward. The two-digit city areas, 01(N), $02(\mathrm{NE}), 03(\mathrm{NW}), 04(\mathrm{SE}), 05(\mathrm{SW})$, and 50 are areas earlier defined by the Portland Development Commission as HCD areas, or in the case of 50 , as a city-wide, non-HCD area code.

The date of the loan is simply the month (two digits) and year (two digits) of the loan. Sex was coded so that $1=$ male and $2=$ female. Age was simply copled into the data set. Six categories, however, were allotted for marital status :

$$
\begin{array}{ll}
1=\text { Single } & 4=\text { Divorced } \\
2 \text { - Married } & 5=\text { Widow }(e r) \\
3 \text { - Separated } & 6 \text { - Cohabitation }
\end{array}
$$

Race was given five one-digit categories

$$
\begin{aligned}
& 1 \text { - White } \quad 4 \text { = Spanish American } \\
& 2 \text { - Black } \quad 5 \text { - Orlental } \\
& 3 \text { - American Indian }
\end{aligned}
$$

Household size and number of dependents were each given two digit codes in case families over ten in number. Occupation codes, allotted two diglts, proved more complicated. The Bureau of Labor breaks down occupational categories into nine broad categories. Senerally, 01-19 includes 
professional, technical and managerial occupations where 07 is medical, 09 is education, and 15, entertainment and recreation. The second category, 20-29, includes clerical and sales occupations. The third, 30-38, includes service occupations where 31 is food and beverage preparation and 38 is building and related service occupations. Category 40-46 includes agricultural, fishery, forestry and related occupations. The next category, 50-59, includes processing occupations, where 50 is metal processing and 58, textiles and leather. Machine trades occupations fall between 60 and 69, while 70-79 includes all benchwork positions. Category 80-89 includes structural work occupations where 86 focuses on construction. The 90-97 category inciudes miscellanesus occupations. The code for transportation occupations is 91,95 is for utilities, 96 for anusement and recreation, and 97, graphic art work. In ail the divisions having a ninth category, 1.e. 39, 59, etc., that category tends to be a miscellaneous catch-all. For this study, two additional divisions were added. Where a recipient reported that he or she was on welfare or unemployment, 97 was used. People on social security or another retirement pension plan were coded 98 . Housing costs per month included mortgage payment, ground rent if any, hazard insurance, real property taxes, maintenance, heat and utilities. Since no housing unit registered had over 9 bedrooms, the number of bedrooms were copied directly into a single digit position. Square footage, the actual floor area of the house, was also copied directly into the data file created for this analysis. It should be noted that for many of the reciplent files, the only square footaje information available was the amount of the area to be rehabilitated. Since this did not necessarily coincide 
192

with the footage of the house itself, a single digit variable was developed to single out cases where only the improvement area was given. Unless square footage numbers found in the files were reported or assuned to include the entire floor space of the unit, a 1 was coded for the "Improvement Area" variable. The year a home was built was used directly. Purchase price, current assessed values, and value after rehabilitated were coded as oiven in the reciplents' files, though mortgage balances were transformed into 1977 dollars. Since the years given for purchase date and assessed value all took place post 1900, only digits were used for those variables. Finally, a single digit general variable was used as a miscellaneous cate §ory as can be seen from its codes.

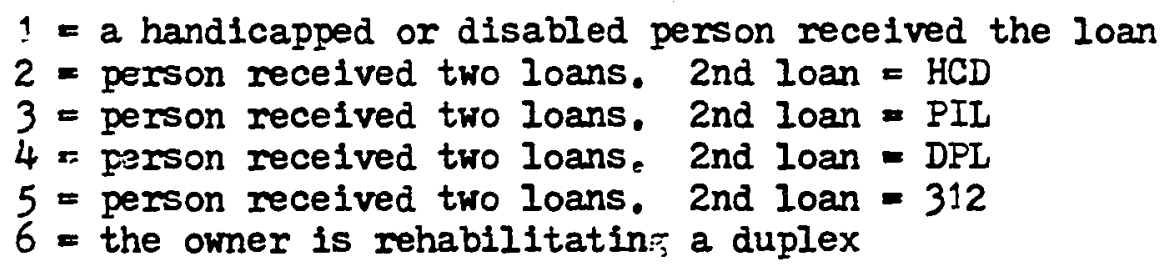

During the analysis some of the numeric variables were broken down into fewer categories for comparative purposes. Ioan amounts were classified into four categories: $\$ 0-\$ 2,500, \$ 2,500-\$ 5,000, \$ 5,000-$ $\$ 10,000$ and over $\$ 10,000$. Monthly income was also transformed into four catezories: $\$ 0-\$ 500, \$ 500-\$ 1,000, \$ 1,000-\$ 1,500$, and over $\$ 9,500$. Liquid assets were given three: under $\$ 500, \$ 500-\$ 3,000$ and over $\$ 3,000$. Housing costs per month and assessed values for homes were each given five categories. Housing costs included 8 under $\$ 100$, $\$ 100$ - $\$ 200, \$ 200-\$ 300, \$ 300-\$ 400$ and over $\$ 400$. Assessed values had: under $\$ 10,009 \$ 10,000-\$ 15,000, \$ 15,000-\$ 20,000, \$ 20,000-$ $\$ 25,000$ and over $\$ 25,000$. Iastly, ages were classified in the followIng manner, 0 - 30 years old, $30-40,40-50,50-60$, and over 60 years old. 
APPENDIX B: SAMPLIN = ERRORS 
The Table below, from E. Terrence Jones, Conducting Political Research, 1971, shows levels of risk and accuracy for sample sizes with an $N$ around 400. The table assumes maximum variability so that the accuracy is probably understated for most studies, including this one. The table also assumes random sampling. Finally, the table is only appropriate for those instances where the population size is at least five times as lar;e as the sample size. For all of the survey work associated with this study, populations were at least five times as larze as shown in Chapter I.

SMAPLE SIZE FOR VARIOUS IEVEIS OF RISK AND ACCURACY

Desired Accuracy Risk of Sample Estimate Being Outside Accuracy Iimits

$\begin{array}{rrrrr} & 1 \% & 2 \% & 5 \% & 10 \% \\ +-4 \% & 1037 & 846 & 600 & 423 \\ +-5 \% & 663 & 54 ! & 384 & 27 ! \\ +-6 \% & 461 & 376 & 267 & 188 \\ +-7 \% & 339 & 276 & 196 & 138 \\ +-8 \% & 259 & 212 & 150 & 106 \\ +-9 \% & 205 & 167 & 119 & 84 \\ +-10 \% & 166 & 135 & 96 & 68\end{array}$

The second table shows the maximum sampling errors for various subsamples. Most results outlined in this study will have a maximum sampling error of less than $+-9.9 \%$ due to the tendency of people to respond at the hirh extremes, 1.e., "Very jood", to survey questions. 
195

MAXIMUM SAMPLINg' ERRORS FOR VARIOUS SUBSAMPLES

Percent Distribution

$$
\begin{aligned}
& 90 / 100 \% \\
& 80 / 20 \% \\
& 70 / 30 \% \\
& 60 / 40 \% \\
& 50 / 50 \%
\end{aligned}
$$

Sample Sizes

$\begin{array}{llll}200 & 100 & 50 & 25 \\ +-4.9 \% & +-7 \% & +-9.9 \% & +-14 \% \\ +-6.6 \% & +-9.4 \% & +-13.3 \% & +-18.8 \% \\ +-7.6 \% & +-10.7 \% & +-15.2 \% & +21.5 \% \\ +-8.1 \% & +-11.5 \% & +-16.2 \% & +-23.0 \% \\ +-8.3 \% & +-11.7 \% & +-16.6 \% & +-23.5 \%\end{array}$

Source I Portland, Oregon (1978). Neighborhood Livability Project. Phase II Report Appendix $B$. 
APPENDIX C: STATISTICAL TOOLS USED 
Contingency tables or crosstabs, are simply joint frequency distributions of cases according to tho or more classificatory variables. The variance of a variable is a measure of the dispersion of the data around the mean of that variable. In a oneway analysis of variance with a single dependent variable $Y$ and an independent variable $A_{0}$ the sum of squares in $Y$ or its spread, can be decomposed into two independent components 8 the sum of squares between the varlables and the sum of squares within the variables. The formula of the sum of squares between equals $\sum_{j} i j\left(\bar{Y}_{j}-\bar{Y}\right)^{2}$ where $\bar{Y}_{j}$ is the mean of $Y$ in the caterory $j$ and $M_{j}$ is the number of cases in category $j$. In other rords, the SS between is the portion of the sum of squaiss in $Y$ due to factor $A_{0}$ SS within equals $\sum_{j} \sum_{i}\left(Y_{i i}-\bar{Y}_{j}\right)^{2} \quad 1 . e .$. the portion of the sum of squares in $y$ due to the variation within each of the categories of A. SS within is not accounted for by $A_{\text {. }}$

The sum of squares becomes greater as the differences among the means of the dependent variable in varlous categories of the independent variable increase and as the varlations in within the catezories of the independent variable decrease. Whether such differences are to be considered substantial or trivial depends on the overall variability of the entire sample and on the varlability within each category of the independent variable. Bta, which is used in this analysis, provides a descriptive statistic capable of comparing the variability or the effects of the independent variable on the dependent variable. Its formula is

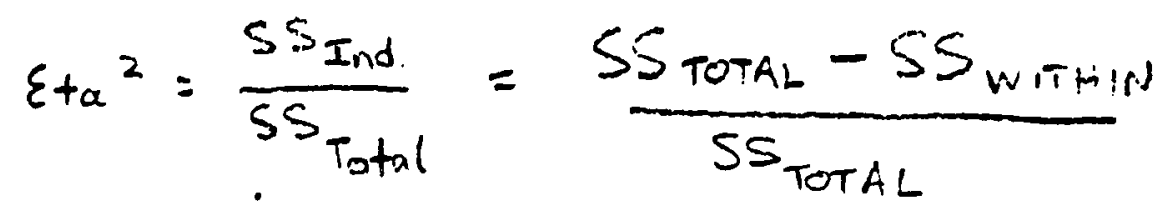


The value of $\mathrm{Eta}^{2}$ will be 1.0 if and only if there is no varlability w1 within each category of the independent variable and there is some variability between categories. It will be zero if and only if there is no difference among the means of the three categories. Consequently, while eta2 $=0$ indicates that there is no effect of the independent variable, the more it approaches a value of 1.0 , the stronger the effect of the independent variable on the dependent variable.

The F test, also used here, tests the null hypothesis that eta $2=0$ or that the variation between groups is significantly greater than the variation within those groups (Kim and Kohout (1970), 400-401). The table shows a typical analysis of variance table and includes formulas used to determine F. (See Attached Table).

For the chapters dealing with specific attitudes toward neighborhood variables, the median test was often used. That test simply compares groups according to how they deviate from a general median for all the groups combined. Recall that the median is defined as the point at, or below which, $50 \%$ of the cases fall. The null hypothesis tested is that $J$ different groups are absolutely identical in terms of their distributions, 1.e. in how they deviate from the general median. It turns out that the formula

$$
z^{2}=\frac{(N-1)}{a(N-a)} \sum_{j=1}^{J}\left(N_{a_{j}}-n_{j} a\right)^{-}
$$

provides the test for deciphering whether two groups have distributions, or patterns, which closely resemble each other. The higher $x^{2}$ is, the more likely two sroups differ.

Tau C is a measure of assoclation which was also used in the study. It can Indicate how strongly two variables are related to each other. 
TABLE

Source

Between Groups

Total within Groups $\quad \sum_{j} \sum_{i} y_{i j}^{2}-\sum_{j} \frac{\left(z_{i} y_{i j}\right)^{2}}{n_{j}}$

SS

$\Sigma_{j}\left(\Sigma_{i, y_{i j}}\right)^{2}-\left(\Sigma_{j} \Sigma_{i} y_{i j}\right)^{2} \quad \frac{5 s \text { between }}{J-1}$

$\frac{n_{j}}{N}-\frac{j}{N}$

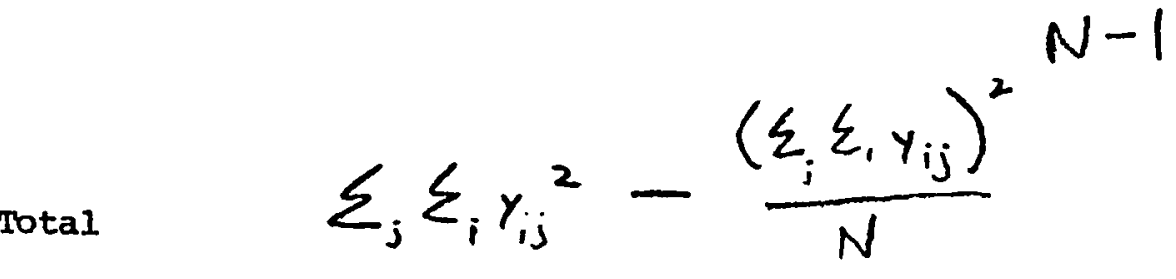

Source: Hays, 1973: 475.

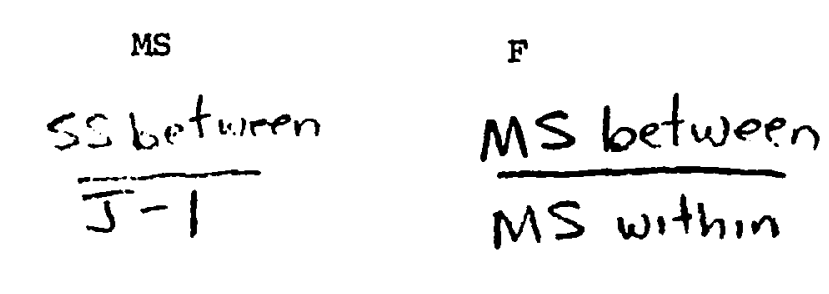

$\frac{\text { SS within }}{N-J}$

范 
Put another way, its value indicates to what extent characteristics of one sort and characteristics of another sort occur tozether. The more often characteristics tend to occur to:ether, the larger Tau $C$ is. Together, the median test and Tau $C$ provided effective tools for determinin? whether the neighborhoods differ statistically in satisfaction levels and characteristics as well as how interrelated these levels and characteristics may be. 
APPENDIX D\& LETTER OF INTENT 


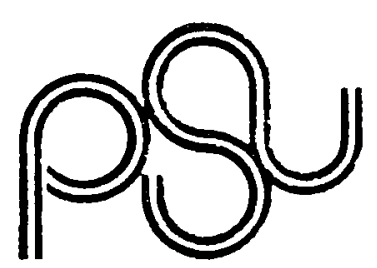

December 30,1978

He110.

I am writing to ask you to take pert in a study I em doing. Fiy final project as a groduete stucielt at Portlard State University is to look et how some of Portland's inner city neighborloods have chenged over the last three yaars.

I need youn help. I would like to come to is' you some questions about how you feel sbout where you live, like whether you have seen any improvements in the past few years and how the city night be able to improve neighborhood conditions there.

I only need about 15 minutes of your time end everythins you tell me can be kept strictly confidential. Miy survey will. start on the Iirst of January ana should last until February.

I plan to trik to people late in the alternoons on weekdays or on weekends and will be happy to tell you. about my study after. I ask you my questions.

Unless I hear otheroise, I will assume you ere willing to relp ree. If you heve any questions you can leave $\varepsilon$ message for me at the School of Urban ifféirs, $229-4043(9$ a.m. $-5 \mathrm{p} \cdot \mathrm{m}$.$) .$

Thank you for your heIp.

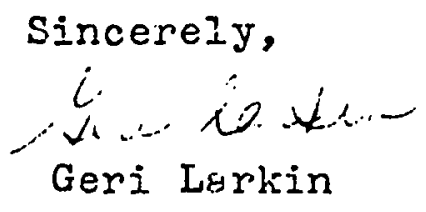


APPENDIX E: QUESTIONNAIRE 


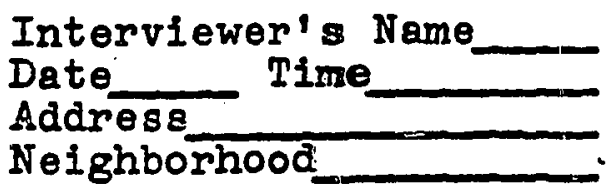

1. First, how long have you lived in this neighborhood?

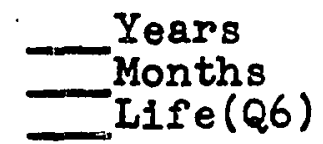

2. When you came here, did you move from a city, a suburb of a efty, a small town, or from the country?

3. What city was that?/What city wes that a suburb of?

4. (IF PORTLAND) What neighborhood was that?

5. Why did you move to this neighborhood?

6. Considering everything, what would you say about this neighborhood as a place to live? Would you say it is a very good place to live, fairly good, neither good nor bad, not very good, or no good at all?

--Very good
--Fairly good
--Meither
--Mot ve good
-- Dot good at al1

7. What about the people who live around here? As neighbors would you say that they are very good, fairly good, neither good nor bad, not very good, or not good at all?

- Wery good

- Fairly good

- - Weither

- - Hot v. good

- Hot good at ali.

8. Of the ten families that live closest to you, how many would you say you know by name?

9. Of these ten famllies, how many have you ever visited with, elther in their home or in yours? 
10. Have many new people moved into the neighborhood in the last threo years? - No

11. Has the type of person moving into the neighborhood in the last three years changed?

12. How so?

13. What about the condition of the houses in the neighborhood? Overall, would you say they are very well kept up, fairly well, not very well, or not kept up at ail?

--Very well

- Fairly w.

- Not very

14. (DO NOT ASK THIS QUESTION OR Q 15 IF THE PERSON - Not kept HAS IIVED IN NEIGHBORHOOD ALL HIS OR HER LIFE) Compared with where you lived before, is the housing in this neighborhood newer, about the same, or older?

15. Compared with where you Iived before is this neighborhood more crowded, about the same, or Iess crowded?

16. How satisfactory is your (house/apartment) as a

place to Iive? Would you say it is very good,
good enough, not so good, or no good at all?

place to Iive? Would you say it is very good,
good enough, not so good, or no good at all?

- Newer

- Same

$-01 d e r$

--More c.

- Same

-Less c.
--Very good
--Good
- -Not so $\mathrm{B}$.
-Not good st all

17. Do you own or rent your home?

18. Have you owned a house before?

--0 wn

- Rent Other

(Specify)

In this house/apartment:

- - Yes

-- No

19. Is the amount of space for your family very good, good enough, not so good, or no good at all? --V. good

--Good enough

-Not so $800 d$

20. Is the number of bedrooms....

- No good

--V. good

--Good enough

- Not so good

- No good 
21. Is the heating in winter...

-- V. $800 d$

- Good $\theta$.

-Not so $\mathrm{g}$.

22. Is the plumbing....

-No good

$--V \cdot$ good

- Good $\theta$.

- Not so

- No good

23. I'd like to ask you how satisfied you are with some of the main services the city provides for the neighborhood. What about street lighting--is it very good, good enough, not so good, or no good at all?

24. How about police protection, is 1t...

-- V. good

- -Good e.

- Not so 8 .

-No good

$--V \cdot 800 d$

- -Good $\theta$.

- Not $80 \mathrm{~B}$.

- -No good

25. The city is charged with the responsibility of keeping the streets repaired and clean--is the service you get in this neighborhood....

26. Thinking about services like schools, parks, -- V. good --Good e. - Not so 8 . and so forth, do you think this neighborhood gets better, about the same, or worse serwices than most other parts of the city?

--Better - Same - Worse

27. (DO NOT ASK RESIDENTS OF ONDER 2 YEARS) Thinking back over the past couple of years, do you think that life for people in the neighborhood has been getting better, staying about the same, or getting worse?

--Better --Same

28. (DO NOT ASK RESIDENTS OF UNDER 2 YEARS) - Worge Heve you noticed improvements in services in the neighborhood in the last couple of jears. like curbs on the streets or new trees?

29. What improvements have you noticed?

30. Have you heard or do you know about any programs or things the city is trying to do to makre things better for people in this neighborhood? 
40

31. What kinds of things have you heard about?

32. Have you ever heard about the city's subsidized homeowner loans for rehabilitating housing?

$$
\begin{aligned}
& \text {--Yes } \\
& \text {--No(if } \\
& \text { owmer: } 051 \\
& \text { renter:Q62) }
\end{aligned}
$$

33. How did you hear about the loans?

34. (FUR OWNERS OF UNDER 3 YEARS)

Did knowing about the loans affect your decision to purchase a home in this neighborhood? --Yes

$$
-\infty \mathrm{No}
$$

35. Have you ever received a subsidized rehabilitation loan from the city?

36. What kind of loan did you receive?

$$
\text { - No (Q5O) }
$$$$
--D P L
$$$$
--\mathrm{HCD}-3
$$$$
--312
$$$$
-- \text { PII }
$$

37. How much was the loan for?

$\Phi$

38. In general, do you think the loan program is very good, good enough, not so good, or no good at all?

-- V. good

- Good e.

- Not so $\mathrm{g}$.

39. How would you rate the services of the Portland

-No good Development Commission during the processing of the loan?

40. Why?

41. What improvements did you make?

--Excellent

--Good

--Poor

42. How would you rate the work done?

43. Why?

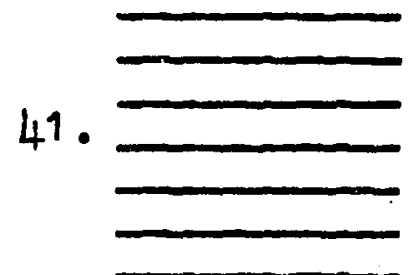

-Excellent

- Good

- - Poor

44. Was your loan sufficient to pay for all the work you wanted to do? 
45. Did you use your own money or money from any other sources to do any additional. rehabilitation work?

- Yes

- No

46. If you had not received a loan would you have made any improvements on your home? --Yes

47. How would you have paid for them?

- No(Q48)

48. Would you recommend the loan program to your neighbors?

-- Yes

49. Why?

- No

50. Have you made $\frac{\text { GO TO QUESTION } 55}{\text { Improvements on your home in }}$ the last three years?

--Yes

- No $(6.57)$

51. What improvements did you make?

52. How much did you spend?

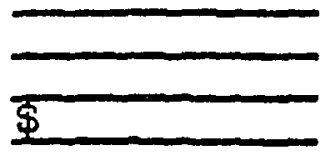

53. How did you finance the improvements?

54. (IF LOAN) What was your interest rate?

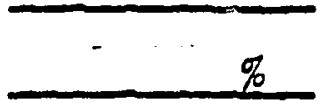

55. Do you think improving your home has affected the neighborhood at all?

--Yes

56. How?

- No (Q57)

57. Have any of your neighbors improved thei $r$ houses in the last three years? --Yes

- No(Q62)

58. (ONLY ASK RESPONDENTS WHO HAVE IMPROVED THEIR HOMES) Do you think they improved their houses because you did? --Yes

59. Why do you think that?

- No

60. Do you think your neighbors improving their homes affected you at all?

61. How?

- Yes

$--N o(Q 62)$ 
62. All things considered, how satisfied or dissatisfied are you with this neighborhood as a place to live, completely satisfied, mostly satisfied, neutral, mostly dissatisfied, or completely dissatisfied?

- Satisfied

- Mostiy sat.

- Neutral

- Mostly dis.

-Dissatisfied

63. What do you think are the most important things that should be worked on to make your neighborhood a better place to live?

64. Five years from now, do you think you will still be living in this neighborhood?

65. Why not?

- Yes (Q67)

- No

66. Where do you think you will be living?

67. Now I would like a little background information on you and your family. Are you now married, living with someone but not married, separated, single, widowed, or-divorced?

--Married --Cohabit

--Separated

- Single

-Widowed

--Divorced

68. What was the highest grade of school you completed?

69. (IF MARRIED OR IIVING WITH SOMEONE) What was the highest grade of education your spouse/ the person you are living with) completed?

70. It would help me if you would tell me all the people who live with you in this apartment/house. Let's start, with the oldest:

\begin{tabular}{l|r|r|l|l}
$\begin{array}{l}\text { LIST ALI PERSONS } \\
\text { MO RELATIONSHIP }\end{array}$ & $\begin{array}{r}\text { SEX } \\
\text { T1. RESPONDENT }\end{array}$ & $\begin{array}{c}\text { AGE } \\
\mathbf{7 2 .}\end{array}$ & $\begin{array}{l}\text { WHAT DOES... DO?* } \\
73 .\end{array}$ & $\begin{array}{l}\text { ABOUT HOW } \\
\text { MUCH INCOME } \\
\text { DOES HE/SHE } \\
\text { EARN MONTHLY? }\end{array}$ \\
\hline & & & & \\
\hline & & & & \\
\hline & & & & \\
\hline
\end{tabular}


*USE SUFFICIENT PROBES TO FIT EACH PERSON INTO ONE OF THE FOLLOWING CATEGORIES:

1. Presently working

2. Has job but not presently working

3. Unemployed and looking for work

4. Unemployed but not looking for work

5. Unable to work (Disabled, handicapped....)

6. Retired

7. Student

8. Housewife

DURING THE PAST MONTH DID ANYONE IN THE HOUSE RECEIVE INCOME FROM:

75. Social Security?

76. Other retirement pay or pensions?

77. . Unemployment compensation?

78. A second job?

$$
\text { 75.-- Yes }
$$

-No

76. - Yee

-No

78.--Yes

79. Assistance or welfare payments of any kind, such as ADC?

79.---Yes

THANK RESPONDENT

(TO BE COMPLETED AFTER INTERVIEW)

Time interview completed

Race

- White

- Black

--Asian

-Other

Respondent's cooperation was:

--V. Good

--Good

- Fair

-apor

Any unusual problems with the interview:Detail below. 
APPENDIX $F \&$ OPTIONS FOR REHABILITATION WORK 
1. Open Space

AII weather parking areas and driveways may be provided.

2. Parking Structures

Parking Structures that are economically infeastble for rehabilitation or do not meet the space requirements of modern transportation may be repleced with a parking structure no greater than 12 feet in width and 22 feet in depth.

3. Fences

Fences may be provided suitable to the property.

4. Insulation

Where existing walls and top floors do not have insulation, the proper amount may be installed to prevent excessive heat loss and to provide comfort for residents.

5. Windows, Doors, and Other Openings

Screens and strom windows may be provided for all doors, windows, and other openings.

6. Privacy and Arrangement

When the bathroom is separated from all bedrooms of a living unit by a full story above or below the bedrooms, a second bath may be installed.

7. Kitchen Storare Space

Additional kitchen storage space may be installed if the existins cabinets are less than the following minimums:

a. Total shelving in wall and base cabinets: $30 \mathrm{sq}$. ft.

b. Drawer area: $5 \mathrm{sq}$. ft.

c. Usable storage shelving in cooking range or under sink may be counted in total shelving needed.

Kitchen storafe space of living units having two or more bedrooms should be appropriately increased in total area to accommodate the needs of more occupants.

8. Carpeting

Wall-to-wall carpet may be installed as a funish floor, provided installation is over a suitable underlayment.

9. Interior Decorating

Interior painting and wall coverings sultable to the structure, conditions, and economics may be applied. 
APPENDIX $\approx$ PORTLAFD DEVELOPMENT COMMISSION

"REHAB COOKBOOK" 


\section{PREFACE}

As part of a continuing effort to conserve older, basically sound residential areas, the City of Portland provides; in certain designated areas, financial and technical assistance to home owners who are otherwise unable to obtain these services.

The process of rehabilitating housing begins with your commitment to provide adequate safe and sanitary living conditions for you and your family and to safeguard the financial investment that you have made in your home.

"Fixing-up a house" is not a difficult job for those individuals who have sufficent experience or adequate guidelines. The REHAB COOKBOOK has been prepared to guide you through the step-by-step "fixing-up" process.

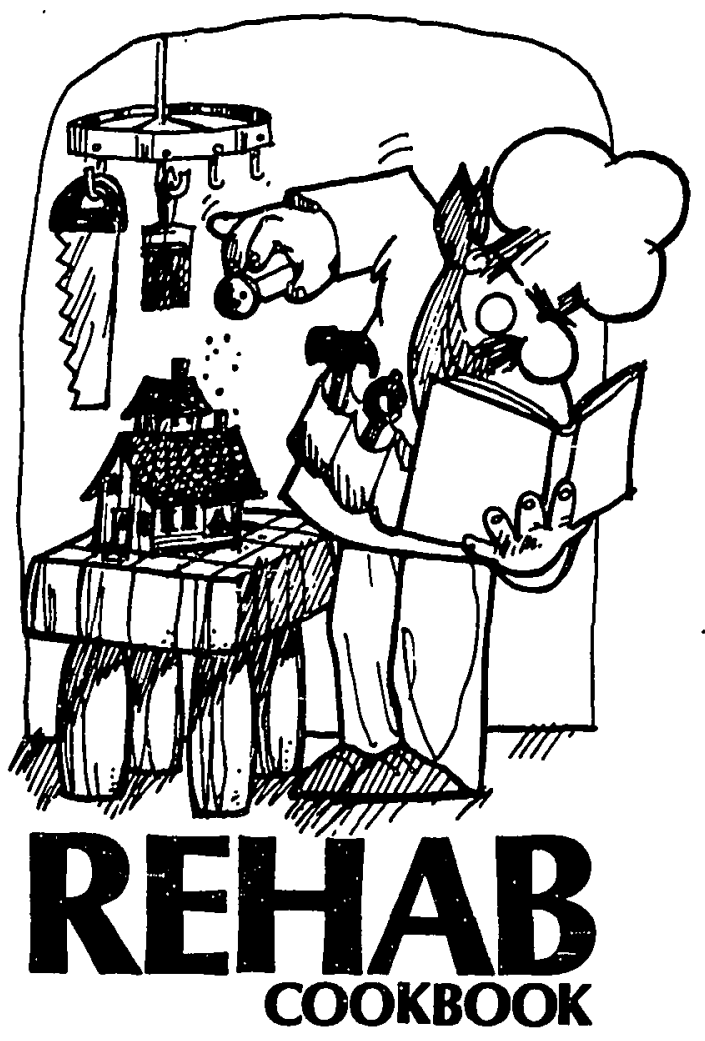

December 1, 1976

City of Portland Development Commission

Housing Assistance Office

1911 Northeast Brosidway

Portland, OR 97232

(503) 248-4900 
Preface

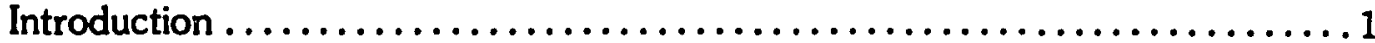

Housing Assistance Programs . . . . . . . . . . . . . . . . . . . . . . . . 2

Designated Housing Assistance Areas . .......................... 3

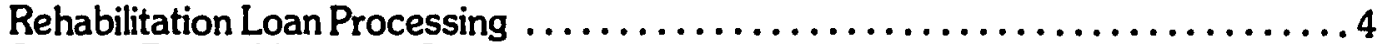

Step 1: Financial Assistance Qualification .......................................... 4

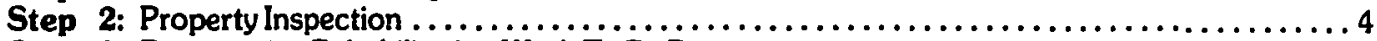

Step 3: Determining Rehabilitation Work To BeDone $\ldots \ldots \ldots \ldots \ldots \ldots \ldots \ldots \ldots \ldots \ldots \ldots \ldots, 4$

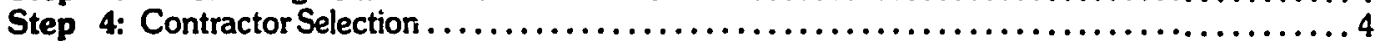

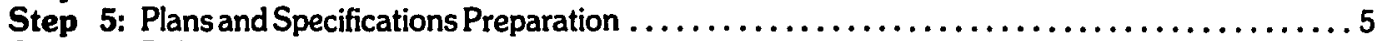

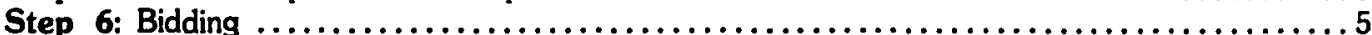

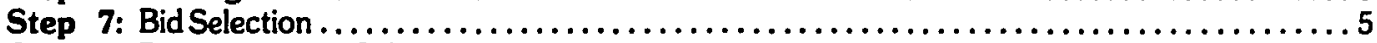

Step 8: Documentation Submission $\ldots \ldots \ldots \ldots \ldots \ldots, \ldots \ldots \ldots, \ldots, \ldots, \ldots, \ldots, \ldots \ldots \ldots, 5$

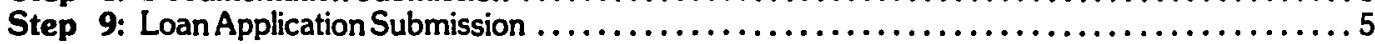

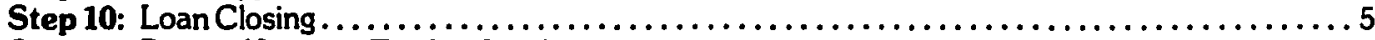

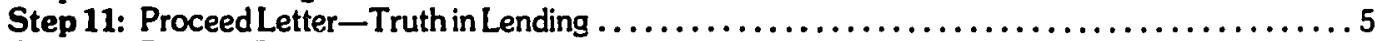

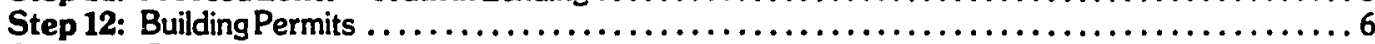

Step 13: Construction Monitoring ..............................................6 6

Step 14: BuildingPermit Completion Certifications $\ldots \ldots \ldots \ldots \ldots \ldots \ldots \ldots \ldots \ldots \ldots \ldots \ldots, 6,6$

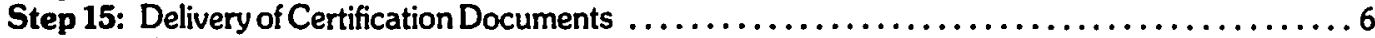

Step 16: Contract Compliance Inspection .............................................6 6

Step 17: Owner's Acceptance and Contractor Payoff $\ldots \ldots \ldots \ldots \ldots \ldots \ldots \ldots \ldots \ldots \ldots \ldots \ldots, \ldots \ldots \ldots$

Housing Code Inspection . ............................... 7

Housing Inspection Letter (example) $\ldots \ldots \ldots \ldots \ldots \ldots \ldots \ldots \ldots \ldots \ldots$

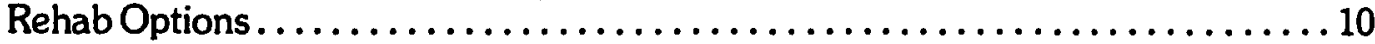

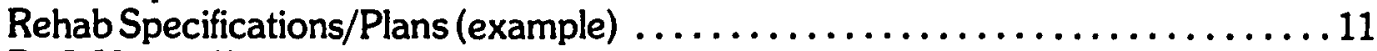

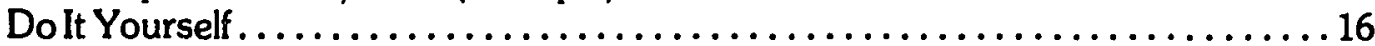

Contract for Homeowner as Contractor (example) $\ldots \ldots \ldots \ldots \ldots \ldots \ldots \ldots$

Certificates of Inspection (example) .............................. 20

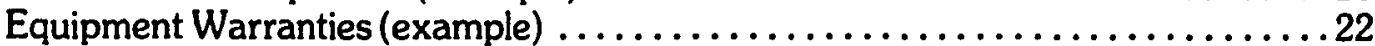

How to Resolve Rehab Work Defects .......................... 24

FORM PACKET CONTENTS

Exhibit

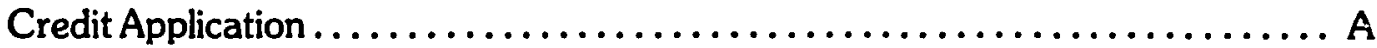

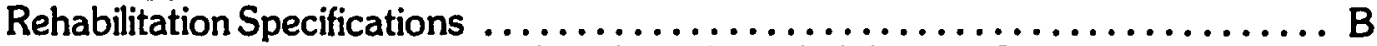

Performance Requirements and Standards for Rehabilitation Contracts ....... C

Bid Proposal and General Instructions ....................... D

Contractors Affidavit, Warranty and Lien Waiver (general) .............. E

Waiver of Lien (specialty and materials) $\ldots \ldots \ldots \ldots \ldots \ldots \ldots \ldots \ldots \ldots \ldots$

Owners Certification and Acceptance of Improvements $\ldots \ldots \ldots \ldots \ldots \ldots \ldots$ G

Certificate of Approval and Disbursement Order ....................

List of General Contractors and Specialty Contractors ................ I 


\section{INTRODUCTION}

The Housing and Community Development Act of 1974 provided the initial authority and funding to establish new housing assistance programs in the City of Portland. As a result, the City of Portland Development Commission has responded with a variety of programs aimed at maintaining and improving the quality of owner-occupied residential properties.

The next two pages briefly describe the types of housing assistance delivered and identify the Housing and Community Development areas in which they are available. The remaining portion of the REHAB COOKBOOK details the complete housing rehabilitation process. Samples of actual documents are included to familiarize you with the program requirements.

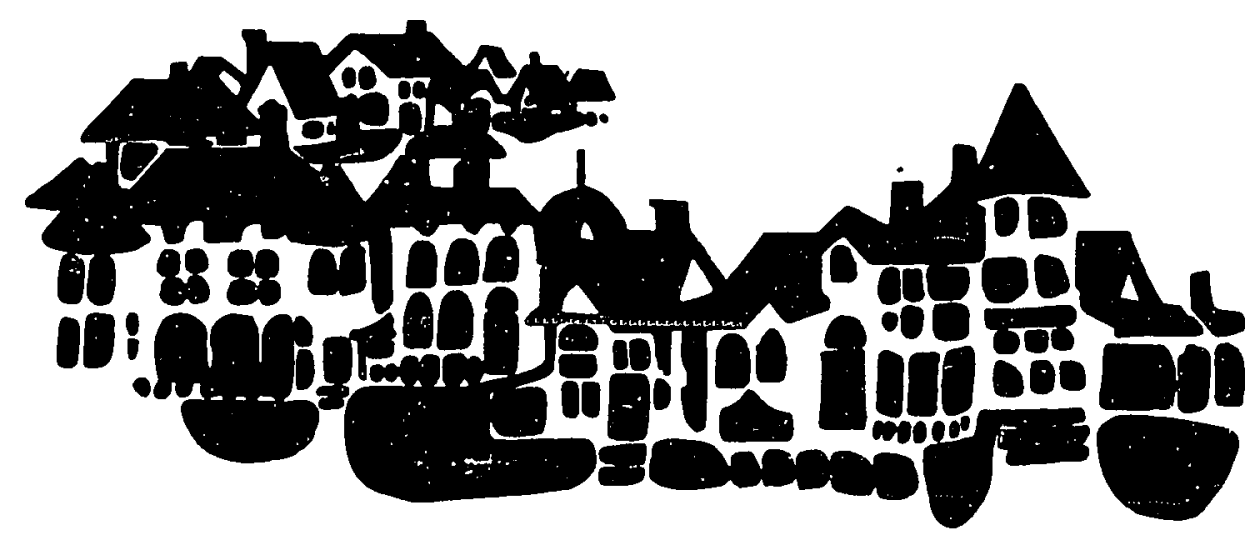




\begin{tabular}{|c|c|}
\hline $\begin{array}{l}\text { CAITICAL } \\
\text { MAINTENANCE } \\
\text { LOAN } \\
\text { (CNL) }\end{array}$ & $\begin{array}{l}\text { Pay for the critical home } \\
\text { repairs only }\end{array}$ \\
\hline
\end{tabular}

$\$ 1,500 ;$ cost of rehab; or amount of equity', whichever is less.

(CML)

\section{DEFERAED}

PAYMENT

LOAN

(DPL)

Rehabilitate home to meet

all applicable housing

codes and ordinances

$\$ 4,000$; cost of rehab; or

amount of equity'.

whichever is less.

\section{HCD-3 LOAN}

Bring property into

$\$ 17,400$ for single family

Property Rehabilitation

household.

amount of equity'

whichever is less.

PUBLIC
INTEREST
LENDER LOAN
(PIL)

Cost of rehabilitating

property up to housing code

compliance; provides for

refinancing
$\$ 17,400$ for single family

residence; cost of rehab; or Fee simple title; or Contract amount of equity', whichever is less.

Owner-Occupant
Owner-Occupant

Fee simple title; or Contract 2 dwelling units maximum

purchaser (obtained interest Critical housing code

1 year prior to application). deficiencies exist

ncome Limits

Payment deferred until property is transfered or sold $0 \%$ Interest Rate

Wner-Occupant

Fee simple title; or Contract purchaser (obtained interest 1 year prior to application). income Limits

Owner-Occupant

Fee simple title; or contract purchaser lobtained interest 1 year prior to application). Income Limits

The ability to repay loan.

Located in City of Portland $\mathrm{HCD}^{2}$ areas City of Portland Payment deferred transferred or sold $0 \%$ Interest Rate g code deficiencies exist.

Maximum 4 dwelling units ocated in City $\mathrm{HCD}^{2}$ area Need of rehabilitation

Residential only

Maximum 20 years $3 \%$ Interest Rate Amortized monthly payments

Located in City HCD² area purchaser (obtained interest Maximum 4 dwelling units 1 year prior to application). Residential only

Maximum 20 years $61 / 2 \%$ Interest Rate Amortized monthly payments

Income Limits

The ability to repay loan.

'Equity will be measured by subtracting the total indebtedness secured by the property from the assessed market value as shown on the most recent property tax appraisal of the property by ${ }^{2}$ Housing and Community the County Assessor. Development

\section{INCOME LIMITS Household Income not to exceed}

Program

\begin{tabular}{lrr} 
& 1 & \multicolumn{1}{c}{2} \\
CML, DPL & $\$ 5,470$ & $\$ 6,125$ \\
HCD-3 & 10,750 & 12,250 \\
PIL & 16,125 & 18,375
\end{tabular}

Household Size

\begin{tabular}{cc}
3 & \multicolumn{1}{c}{4} \\
$\$ 6,875$ & $\$ 7,688$ \\
13,750 & 15,375 \\
20,625 & 23,063
\end{tabular}

\begin{tabular}{cc}
5 & \multicolumn{1}{c}{} \\
$\$ 8,125$ & $\$ 8,625$ \\
16,250 & 17,250 \\
24,375 & 25,875
\end{tabular}

\section{HOUSING ASSISTANCE PROGRAMS}




\section{DESIGNATED HOUSING ASSISTANCE AREAS}

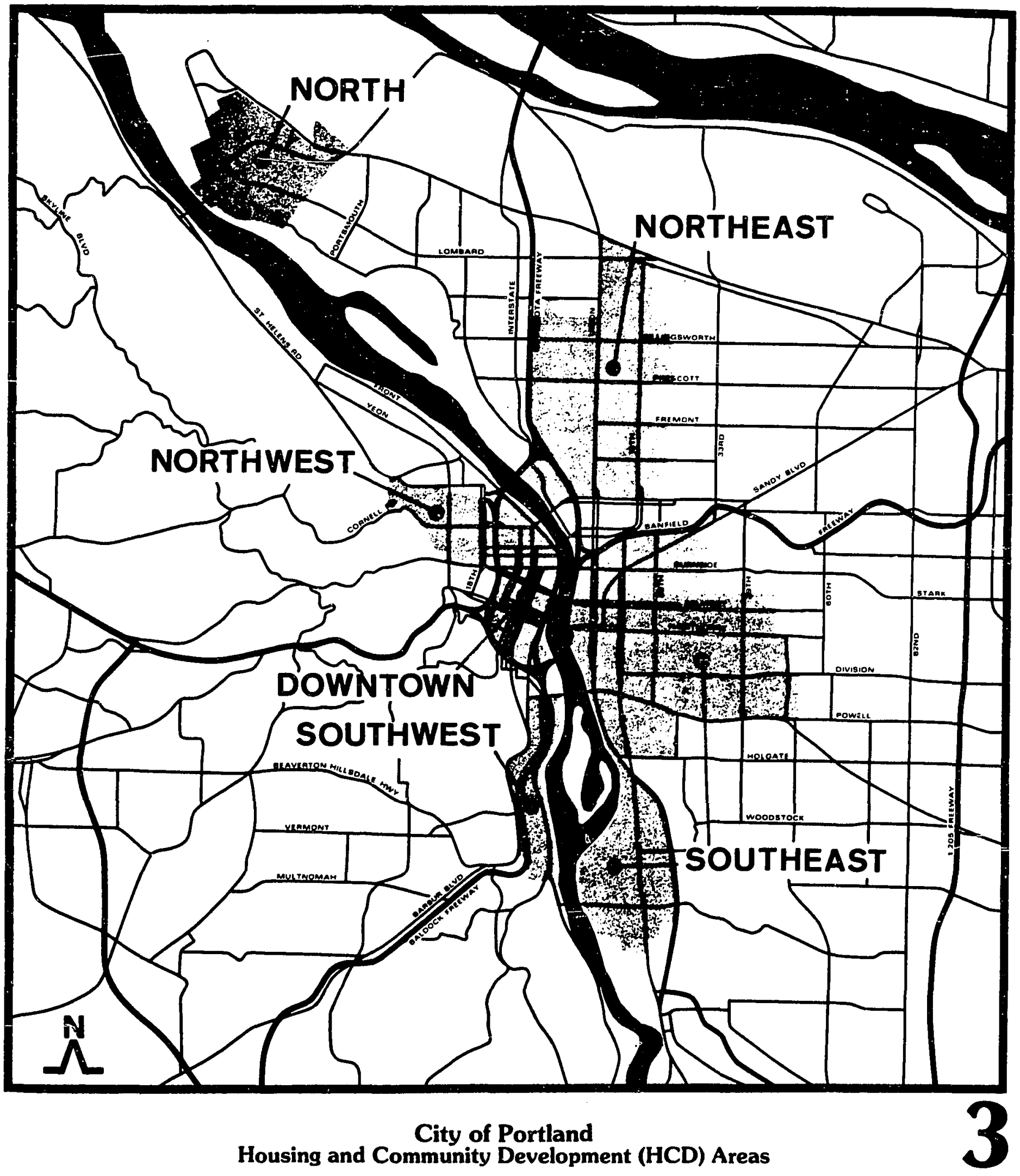


 \\ REHAB LOAN PROCESSING}

Before beginning the repair and upgrading of your home, it is important for you to understand the procedures that must be followed if you expect to achieve the kind and quality of rehabilitation work you are now considering. Study the following processing steps carefully. If you need additional information, please call 248-4900.

\section{Step 1}

Financial Assistance Qualification

All home owners needing rehabilitation financial assistance must fill out the eligibility application (Exhibit A) which is included in the attached packet of forms. Mail or deliver the completed form to the City of Portland Development Commission's Housing Assistance Office, located at 1911 N.E. Broadway, 97232 (telephone: 248-4900). If you wish, a Portland Development Commission staff member will assist you in completing this form. You will be notified by mail of your eligibility status. If you have already done this and have received a letter from the Commission advising you of your qualification for financial assistance, proceed to Step 2.

\section{Step 2}

\section{Property Inspection}

After your eligibility has been determined, call or come to the Development Commission Housing Asssistance Office and arrange for an inspection of your property. All inspection's are made in accordance with Title 29 Housing Regulations of the City of Portland to determine if any housing conditions exist that either do or may endanger you or you: family's health and safety or the financial investment you have in your home. (See inspection illustration, page 7.) You may schedule this inspection at any time at your convenience during the Commission's office hours. A report in letter form of this inspection will be mailed to you. (See page 8 for an example of such a letter.)

\section{Step 3}

\section{Determining Rehabilitation Work To Be Done}

Review the housing deficiencies listed in your inspection report that must be corrected. On page 10 is a list of other items of rehabilitation that are eligible to be included in your loan application, if you so desire, provided that the cost of this additional work does not exceed the loan amount for which you have been qualified. A decision must now be made as to the type and amount of work you will do to rehabilitate your home.

NOTE: Technical assistance is always available to you, without charge, as a separate service or in connection with any source of financing you may select.

Due to the large number of rehabilitation assistance applications processed by the Commission annually, applicants who are unable or unwilling to put forth a continuing effort to finalize their application requirements will be removed from the active processing schedule to make room for those applicants who are ready to proceed.

\section{Contractor Selection}

All registered and licensed contractors may be eligible to participate in Portland's Housing Rehabilitation Program. Included in the form packet which accompanies this manual are two lists of contractors who have asked to participate in the City's rehabilitation programs. These lists of contractors labeled Exhibit $\mathbf{J}$ are for your convenience in selecting craftsmen to do your rehabilitation work. These lists do not represent a recommendation or an endorsement of these firms by the Development Commission. At your request, most contractors will furnish references for you to check out. We emphasize that you should take the time and effort to do this in order to avoid the possibility of future misunderstanding and/or dissatisfaction. 


\section{Step 5}

\section{Step 6}

Step 7

\section{Step 8}

Step 9

Step 10

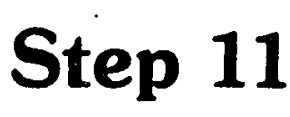

\section{Plans and Specifications Preparation}

Now prepare your rehabilitation specifications and cost estimates. (See example specification documents, pages 11 through 15, and Exhibit B included in the form packet.) Plans need be prepared only if they are necessary to supplement or explain the rehabilitation specifications and/or are a requirement for a building permit. Your Rehabilitation Specialist or contractor will prepare these documents as a part of the contract. The Rehabilitation Specialist assigned to you will answer any questions you may have. A WORD OF CAUTION: Incomplete or unclear plans and specifications frequently lead to needless misunderstandings and dissatisfaction with the work for which you will be contracting.

\section{Bidding}

Request bids from the contractor(s) you have selected, using as a basis for these bids the plans (if necessary) and the specifications prepared by your Rehabilitation Specialist or contractor. Bids must be submitted on the Bid and Proposal documents, Exhibit D, contained in the form packet.

\section{Bid Selection}

After the bids are received, study each for completeness, accuracy and cost. Choose the one you feel will give you the best quality of work for the money you are willing to spend. If you wish, a Rehabilitation Specialist will assist you in this review.

\section{Documentation Submission}

Take or send the plans, specifications and cost breakdown, along with the contractor's bid and your signed acceptance of this bid, to the Housing Assistance Office for review. The loan application and contract documents will then be prepared by the Housing Assistance staff.

\section{Loan Application Submission}

The Housing Assistance staff will notify you when these documents have been prepared. Then you, the homeowner, will be asked to sign the loan application and all other appropriate documents at the Housing Assistance Office. NOTE: No work is to commence until authorized by the Commission.

\section{Loan Closing}

You will be notified by the Commission's Finance Section when the loan has been approved, and a date will be arranged for the closing of your loan. This will include the signing of your rehabilitation contract with the contractor you have selected.

CAUTION: After you and the contractor have signed the rehabilitation contract, any changes in any part of the contract must be in writing and api imved by you, the contractor, and the Development Commission prior to physicai making any such work changes. Unauthorized work changes frequently lead to misuncierstandings and difficulties in bringing the job to a satisfactory conclusion and could result in legal action.

\section{Proceed Letter-Truth in Lending}

Send a letter to the contractor stating the date the work is to begin, which can be no sooner than three (3) days after the contract is signed. This waiting period is required by the federal "truth-in-lending law." If you like, the letter can be prepared by the Housing Assistance staff. 


\section{Building Permits \\ Sten 12 Before starting construction, the contractor must obtain from the Bureau of Buildings, and post on your property, a building permit which will cover every item of rehabilitation work you have specified in your contract. This permit must state the same cost of rehabilitation as does the contract.}

\section{Construction Monitoring}

Stem 13 You, the homeowner, will monitor the construction work for contract compliance during the entire construction period. A Rehabilitation Specialist will be available for consultation.

\section{Building Permit Completion Certifications}

St After the rehabilitation work has been completed, the ccintractor will contact the Step 14 appropriate division (plumbing, electrical, etc.) of the Bureau of Buildings and request inspections of all the work that has been performed under the building permit. When the work is judged by the City Building Inspector to have met the requirements of the City Code, the Bureau of Buildings will issue to the contractor certificates of inspection. (See examples, pages 20 and 21.)

\section{Delivery of Certification Documents}

Ste 15 The contractor will deliver these certificates to you, together with applicable lien waivers, (Exhibits $\mathrm{E}$ and $\mathrm{F}$ of your form packet) and equipment warranties (see example, pages 22 and 23.)

\section{Contract Compliance Inspection}

Stem 16 These documents must then be delivered to the Housing Assistance Office with a request that the Rehabilitation Specialist assigned to your job inspect the property with you to determine whether the conditions of the contract have been fully met.

\section{Owner's Acceptance and Contractor Payoff}

Step 17 Once it has been determined that the conditions of the Contract have been fully met, you will sign an Owner's Acceptance Certificate and an authorization for the City of Portland Development Commission to Pay the contractor. (Exhibits $\mathrm{G}$ and $\mathrm{H}$ of your form packet.) 


\section{HOUSING CODE INSPECTION}

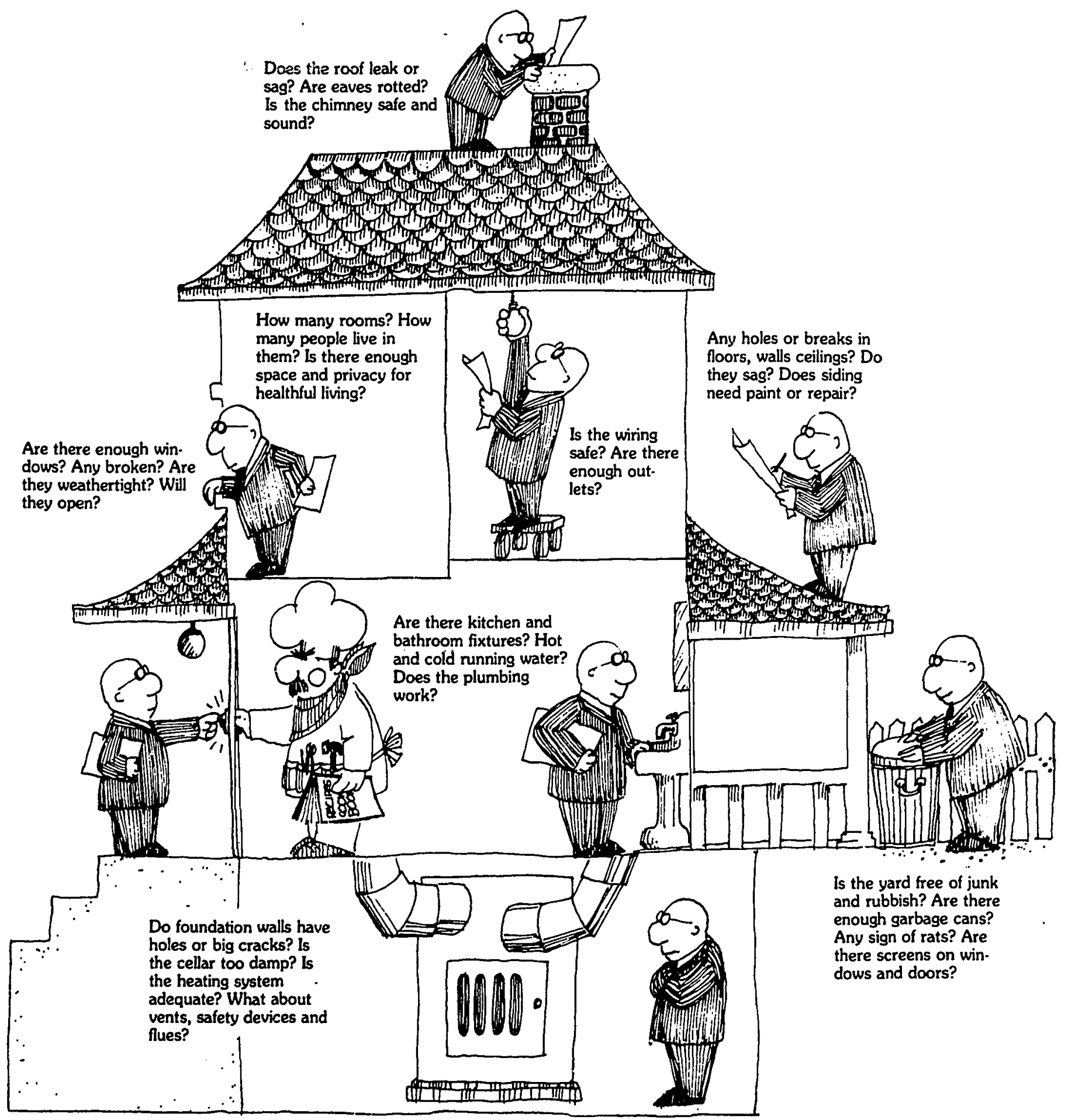




\section{HOUSING INSPECTION LETTER}

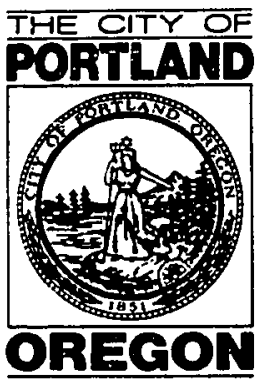

DEPARTMENT OF DEVELOPMENT AND CIVIC PROMOTION

PORTLAND DEVELOPMENT COMMISSION

HOUSINC SERVICES OFFICE 1911 N.E. BROADWAY PORTLAND, OR. 97232 (503) 248.4900
Mr. and Mrs. John Doe 223 N. Olympia Street Portland, OR 97203

Dear Mr. and Mrs. Doe:

November 5, 1976

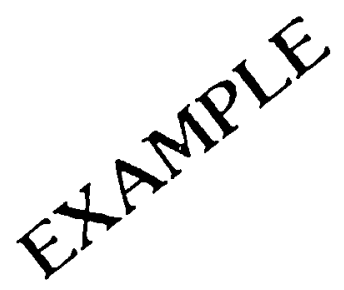

The City of Portland has made a commitment to upgrade its substandard housing by providing financial and technical assistance under a Housing and Community Development Program. As part of this program and at your request, an official inspection has been made of your property located at $223 \mathrm{~N}$. Olympia Street in the St. Johns Housing and Community Development area.

In his report, the Inspector has 1 isted the following conditions which do not meet City Housing Code requirements and therefore constitute fire, safety, or health hazards:

1) Electrical deficiencies noted: Front porch lacks a light and switch and rear entry fixture is damaged; kitchen outlets are inadequate and switches and lights are damaged; living room light switches are defective; dining room outlet is defective; bathroom outlet is not properly grounded; cellar stairway liscks required lighting; northeast and northwest bedroom switches are improperly mounted; meter base is loose and improperly mounter; service panel is inadequate for equipment being served; portions of wiring throughout the dwelling are improperly installed and hazardous; doorbell and transformer are inoperable. Section 29.23.010(d)

2) Plumbing deficiencies noted: All second story bath fixtures, faucets, and drains are worn; damaged, and give evidence of leaking; kitchen sink is worn, chipped, and its drainlines are leaking; cellar laundry trays are cracked and faucets are subject to siphonage; water heater lacks an approved pressure rellef valve assembly; cellar floor draín is partially obstructed; water service line is of insufficient size and pressure to fixtures is restricted; drainlines give evidence of partial obstruction. Section 29.28.010(e)

3) Front yard retaining wall, adjacent to a public way, is damaged and tipping. Section 29.28.010(i)

4) Service walk is broken and unevenly settled. Section 29.28.010(i)

5) Driveway is unpaved and approach apron is broken and settled, safe all-weather access and parking is not provided. Section 29.24.010 and $29.28 .010(i)$ 
Mr. and Mrs. John Doe

November 5, 1976

Page 2

6) Kitchen cabinet doors and drawers are worn and loose, safe storage of food and utensils is not provided; kitchen counter and covering are moisture damaged and unsanitary. Section 29.28.010(b)

7) Bathroom floor covering is moisture damaged and loose. Section 29.28.010(b-13)

City regulations require that you have these conditions corrected after having obtained the proper permits from the Bureau of Buildings.

If you disagree with the inspector regarding any of the conditions listed above, you have the right to appear before the Housing Advisory and Appeal Board and give your reasons. However, Section 29.12.030 of the City Code requires that you make your appeal by giving written notice to the Euilding Inspections Director within five $(5)$ days of receipt of this letter of notification. For more information on this matter, call 248-4245.

In addition to the Code violations listed above, the inspector also found certain conditions which, unless corrected, can be expected to become Code violations. They are as follows:

1) Furnace and ductwork are old and damaged and may have a limited period of usefulness.

2) Kitchen wall and ceiling plaster is cracked and bulged; floor coverings and miliwork are damaged and worn.

If you have any questions regarding this letter of notification, including the substandard conditions found by the inspector, call 248-4900, Portland Development Commission.

\author{
Yours truly, \\ James E. Griffith \\ Director, Bureau of Buildings
}

Don S. Silvey

Manager, Housing Assistance

CHF : jas

cc: Bureau of Buildings 


\section{REHAB OPTIONS}

1) Open Space

All Weather parking areas and driveways may be provided.

2) Parking Structures

Parking structures that are economically infeasible for rehabilitation or do not meet the space requirements of modern transportation may be replaced with a parking structure no greater than 12 feet in width and 22 feet in depth.

3) Fences

Fences may be provided suitable to the property.

4) Insulation

Where existing walls and top floors do not have insulation, the proper amount may be installed to prevent excesive heat loss and to provide comfort for residents.

5) Windows, Doors and Other Openings

Screens and storm windows may be provided for ali doors, windows and other openings.

6) Privacy and Arrangement

When the bathroom is separated from all bedrooms of a living unit by a full story above or below the bedrooms, a second bath may be installed.

7) Kitchen Storage Space

Additional kitchen storage space may be installed if the existing cabinets are less than the following minimums:

a) Total shelving in wall and base cabinets -30 sq. $\mathrm{ft}$.

b) Drawer area -5 sq. ft.

c) Usable storage shelving in cooking range or under sink may be counted in the total shelving needed.

Kitchen storage space of living units having two or more bedrooms should be appropriately increased in total area to accommodate the needs of more occupants.

8) Carpeting

Wall-to-wall carpet may be installed as a finish floor, provided installation is over a suitable underlayment.

9) Interior Decorating

Interior painting and wall coverings suitable to the structure, conditions and economics may be applied.

Other items of rehabilitation not included in this list which are customarily used in similar housing are eligible for inclusion in the loan up to a cost of $40 \%$ of the dollar amount spent on code and optional items. 


\section{REHAB SPECIFICATIONS/PLANS}

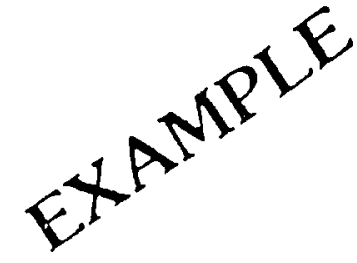

Property: $\quad 223$ N. Olympia Owner:

\section{REHABILITATION \\ SPECIFICATIONS}

Lot: 16

Block: 13 PORTLAND ADD.
Loan No. $38 / R-8 / \cdots-\cdots /-$

Rehab Adv 0. Smith Checked by B. Brown

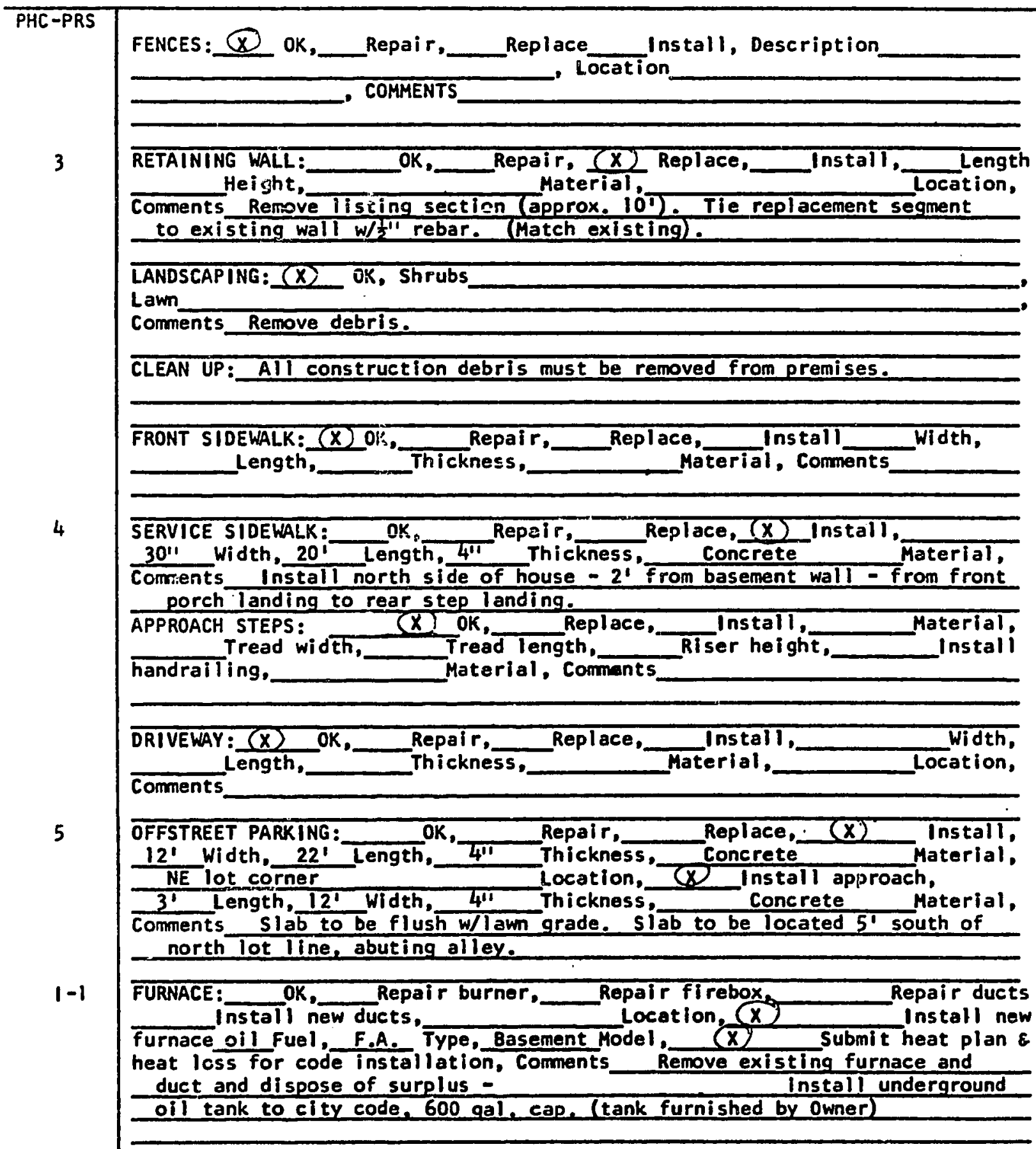


REHABILITATION

SPECIFICATIONS

Lot: 16

Block: 13
Loan No. $38 / R-8 / \cdots--1-$

Rehab Adv 0. Smith

Checked by $B$. Brown

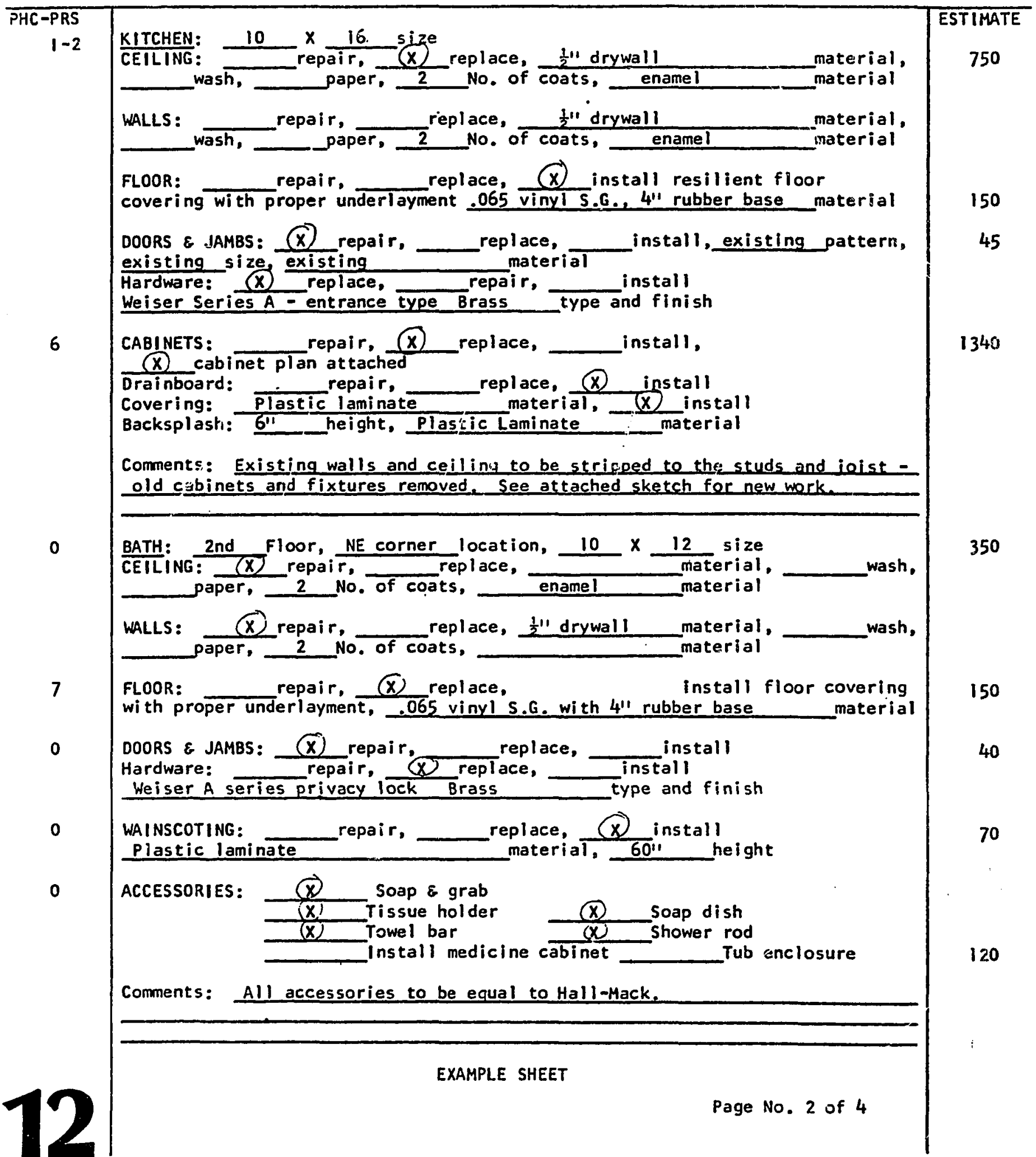


REHABILITATION

SPECIFICATIONS
Loan No. $38 / R-8 \% \cdots--/-$

Lot: $\quad 16$

Block:
Rehab Adv 0. Smith

13 PORTLAND ADD. Checked by B. Brown

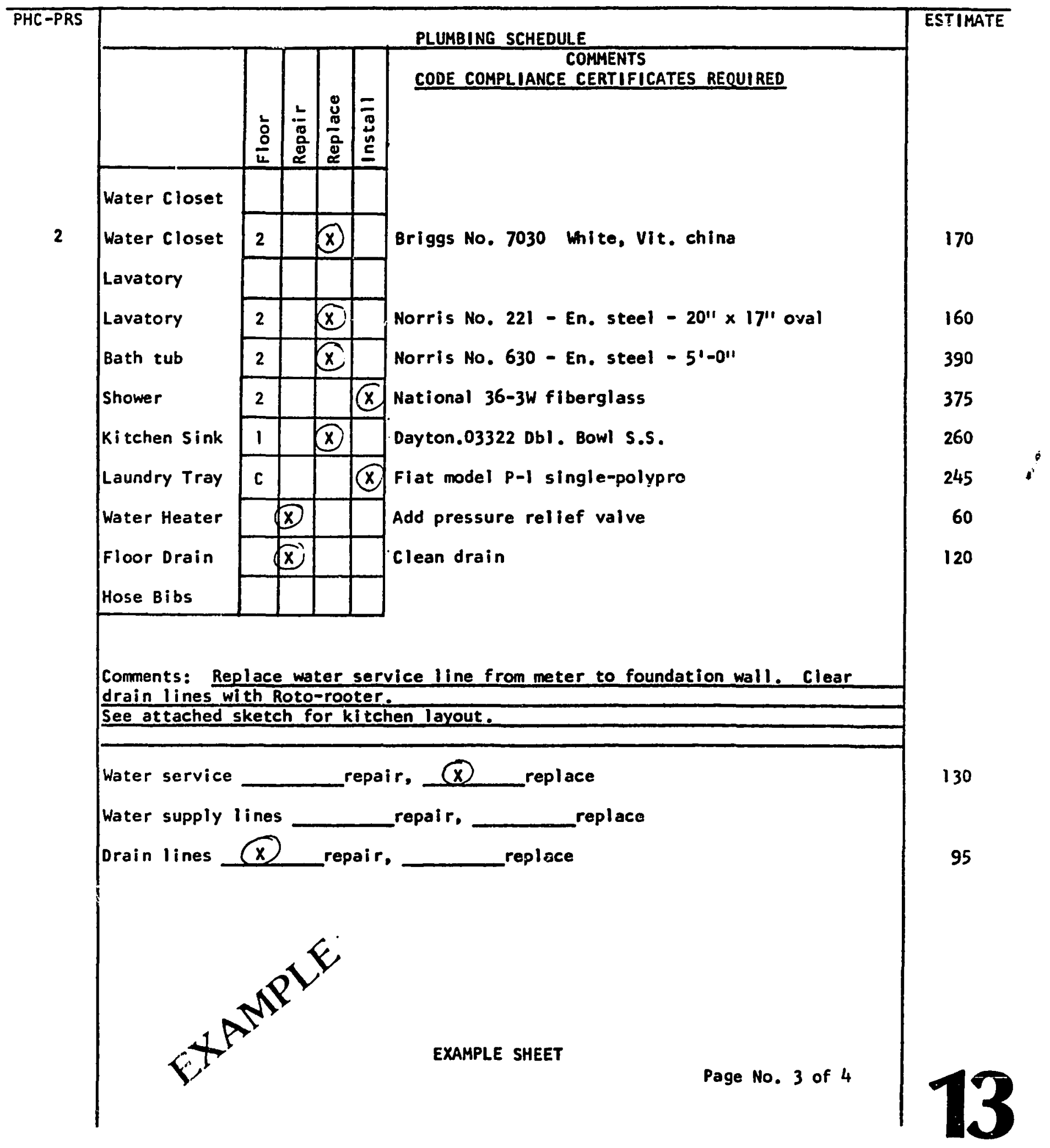




\begin{tabular}{|c|c|c|c|c|c|}
\hline & & $\begin{array}{l}\text { REHABILITATION } \\
\text { SPECIFICATIONS } \\
\end{array}$ & .oan No. & $38 / R-8 /---1-$ & \\
\hline $\begin{array}{l}\text { Property: } \\
\text { Owner: }\end{array}$ & $\begin{array}{l}223 \text { N. Olympia } \\
\text { DOE, John and Jane }\end{array}$ & $\begin{array}{l}\text { Lot: } \\
\text { Block: }\end{array}$ & PORTLAND ADD. & $\begin{array}{l}\text { Rehab Adv } \\
\text { Checked by }\end{array}$ & O. Smith \\
\hline
\end{tabular}

ELECTRICAL SCHEDULE

ESTIMATE

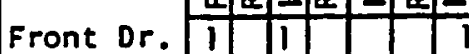

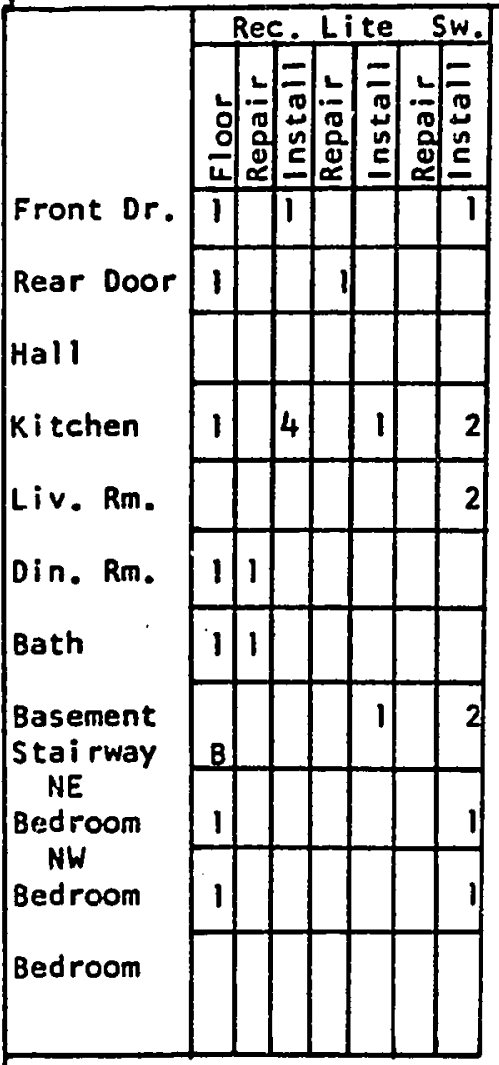

CODE COMPLIANCE CERTIFICATES REQUIRED

FIXTURE NO. PROGRESS P 47

25

3-WAY SWITCHES, FIXT. NO. T3O0 GRAYBAR

190

60

10

FIXTURE - KEYLESS RECPT. 3-WAY SWITCHES TOP

AND BOTTOM OF STAIRS

80

30

30

SERVICE ENTRANCE: Secure meter base to wall

Replace, Comments

Repair. Replace, Comments

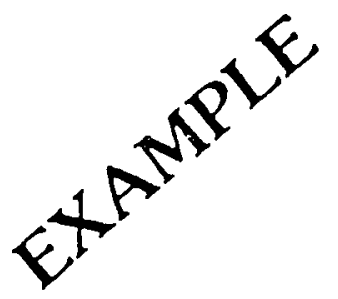

PANEL: $\quad$ OK, Repair, $X$ Replace, Comments

NEW CIRCUITS: As required for new installations

(New furnace circuit and wiring)

80

HAZARDOUS WIRING: Replace all wiring certified unsafe by City Electrical Inspector

DOOREBELL:___ OK, Repair, $(x)$ install, LIGHT FIXTURES Allowance. Location No. Fixtures 
-PORCH

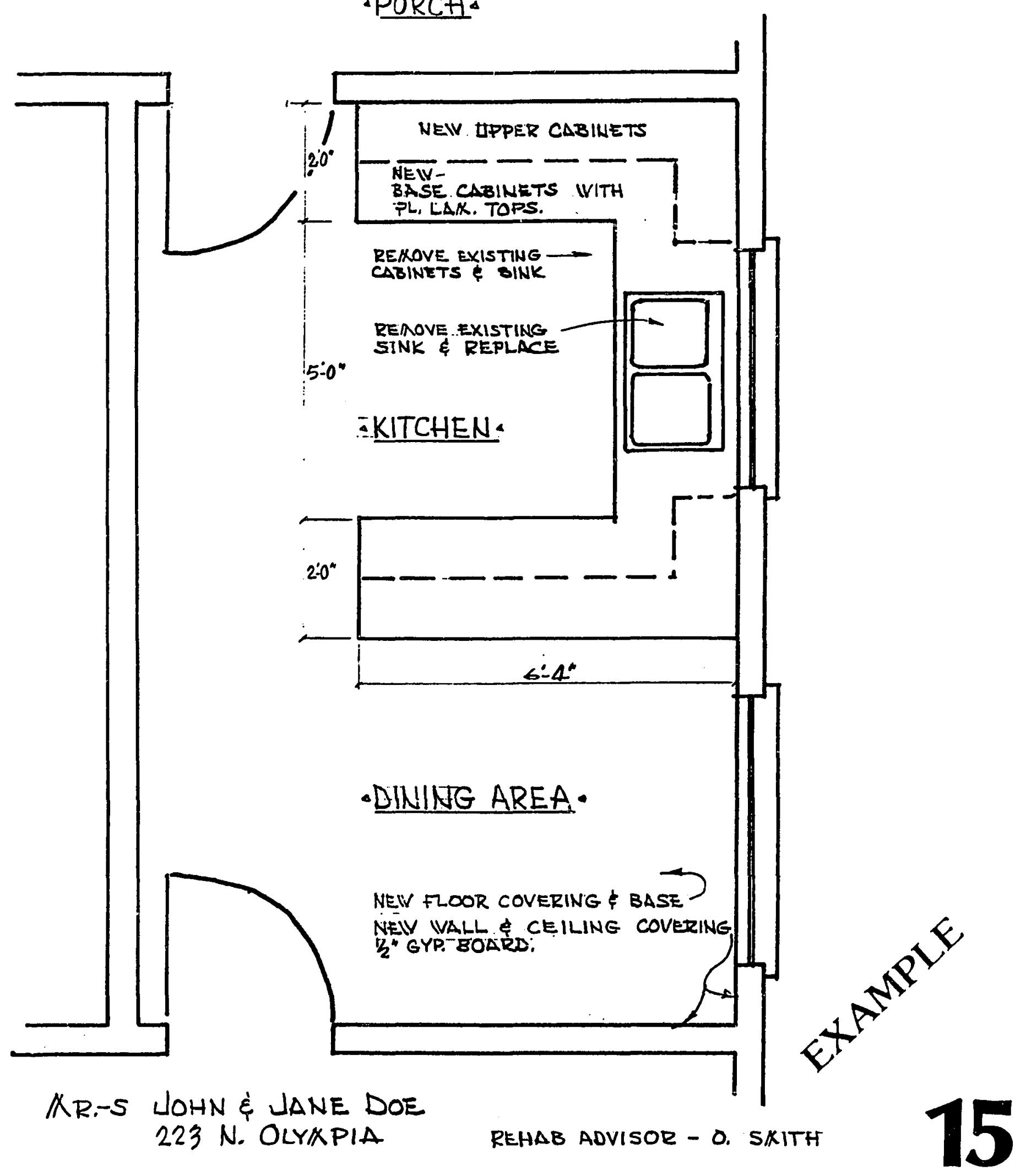




\section{YOURSELF}

\section{INSTRUCTIONS TO HOMEOWNERS WHO DESIRE TO ACT AS THEIR OWN CONTRACTOR}

Homeowners who are willing and able to do all, or part of the functions required to complete the rehabilitation of their homes may substantially shorten the time required to complete their work. This effort allows "self-help applicants" to proceed at a pace. which may be faster than homeowners who need the Commission's staff to handle all their administrative and technical details. Homeowners may act as their own General Contractor if they demonstrate that they are qualified to do so. Specific guidelines have been set up for this procedures as follows:

1) Homeowners shall enter into a written contract with the Portland Development Commission which contains terms and conditions under which the work is to be performed and the payments which will be made from rehabilitation loan funds held in an escrow account managed by the Commission.

2) Homeowners will not be paid for any rehabilitation work performed by the Homeowners themselves or by members of their immediate family.

3) Homeowners shall furnish to the Commission, for all work done by persons other than the Homeowner or members of their immediate family, firm bids which shall include the name and address of the person(s) or business performing the work, a description of the materials to be used, and the manner in which the work is to be accomplished.

4) Final payment will not be made until all the work has been certified complete. However, progress payments may be permitted to avoid hardship to Homeowners in buying materials and contracting for services.

5) Homeowners shall furnish to the Commission a detailed breakdown of labor hired by the hour which shall include the type of labor to be performed, costs per hour, and estimates of the number of hours. All estimates shall be subject to approval by the Commission. Procedures to correct all code violations cited in the inspection report (compliance letter) must be included in the rehabilitation contract documents entered into between the Homeowners and the Commission.

i) All rehabilitation work performed under contract shall comply with all applicable codes and ordinances of the City of Portland. Upon satisfactory completion of the rehabilitation work and final permit inspection, certificates of code inspection must be obtained by the Homeowners from the Bureau of Buildings and delivered to the Housing Assistance Office before final payment of contract funds will be made by the Commission.

8) Homeowners are responsible for scheduling and coordinating the rehabilitation work to assure that it will be successfully completed within the time specified in the contract for completion.

9) Members of the Housing Assistance staff will make a final inspection with the Homeowners to make sure the conditions of the contract have been fully met. Final payment may be made in the form of two-party checks payable to the Homeowners and subcontractor or Homeowners and supplier of materials. (This procedure will also apply to progress payments.) Any unused loan funds will be credited to the outstanding loan balance to reduce the Homeowner's rehabilitation loan. 


\section{CONTRACT FOR HOMEOWNER AS CONTRACTOR}

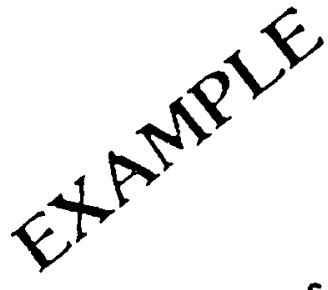
Structure in the City of Portland, Oregon

Loan No.

THIS AGREEMENT

made this day of 19 BY AND BETWEEN

REHABILITATION CONTRACT BETWEEN

PORTLAND DEVELOPMENT COMMISSION

AND HOMEOWNER AS CONTRACTOR

THE PORTLAND DEVELOPMENT COMMISSION, hereinafter called "Commission", and , hereinafter called "Homeowner";

\section{WITNESSETH;}

that in consideration of a home-rehabilitation loan from the Commission, and of promises hereinafter contained, the Homeowner and the Commission agree as follows:

\section{ARTICLE 1. SCOPE OF THE WORK}

The Homeowner will furnish all of the materials and perform, or arrange for the performance of, all of the rehabilitation work on the Homeowner's residence, in accordance with a Bid and Proposal submitted to the Commission by the Homeowner.

The Homeowner will submit to the Commission a list and cost breakdown for all materials used in any work done solely by the Honeowner or members of the Homeowner's immediate family.

For work to be done by others, the Homeowner wlll furnish the Commission with a firm bid or bids and with a detailed list of such work and who will perform it. For labor to be hired by the hour, the Homeowner will furnish the Commission with a detailed breakdown which will include the type of labor to be performed, cost(s) per hour, and an estimate of the number of hours. 


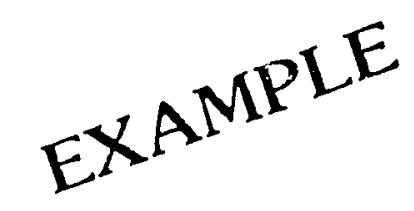

The Homeowner understands and agrees that no payments will be made under this contract for work performed by the Homeowner or by members of the Homeowner's immediate family.

ARTICLE 2. TIME OF COMPLETION

The work to be performed under this contract shall be commenced by , 19_, and shall be completed not later than , 19_. It is the responsibility of the Homeowner

to coordinate and schedule the work for commencement and completion within the above stated dates.

ARTICLE 3. CITY CODE REQUIREMENTS

The Homeowner understands and agrees that the work must comply with applicable requirements of the City Coda regarding building permits and inspections; and that, once the work is completed, the Homeowner must obtain certificates of completion for any electrical, plumbing and furnace work, and that all of the work must be inspected and approved by the Commission prior to final payment. ARTICLE 4. PROGRESS PAYMENTS

As determined by the Commission, one or more progress payments may be permitted to avoid hardship to the Homeowner in regard to contracting for services and/or buying material. However, in making any such payments, the Commission will retain at all times a sufficient amount of the loan funds to complete the work as set forth in this contract. No monies will be advanced for labor or materials. Payments will only be made when materials have been installed in an acceptable manner.

ART.I.CLE 5. ACCEPTANCE AND FINAL PAYMENT

Upon receipt of written notice from the Homeowrer that the work is completed and ready for final inspection and acceptance, the Commission shall 
promptly make such inspection and, if it finds the contract fully performed, shall request $C i t y$ inspection. If, following such inspection, the $C i t y$ issues the :ecessary letter(s) or certificate(s) of code compliance, the balance of the contract sum will become due and payable within fifteen (15) days of such issuance.

If the Commission determines that the work has been substantially completed, but that full completion has been materially delayed through no fault of the Homeowner, the Commission shall make payment to the Homeowner for that portion of the work which has been completed and approved but not paid for under the progress payments, if any.

ARTICLE 6. COMMISSION OBLIGATIONS

The Homeowner understands and agrees that the Commission neither has nor will have any responsibility or obligation, legal or otherwise, in connection with work performed, or material or equipment furnished under this contract except as may be expressiy provided for herein.

The Homeowner further understands and agrees that any warranties or guarantees of the work and materials must be obtained by the Homsowner and that the Commission is not responsible in any way for the quality of such work or materials.

\section{ARTICLE 7. THE CONTRACT AMOUNT}

The total amount to be paid to the Homeowner by the Commission for all work performed and materials supplied according to the terms of this contract shall in no event exceed the maximum sum of (\$

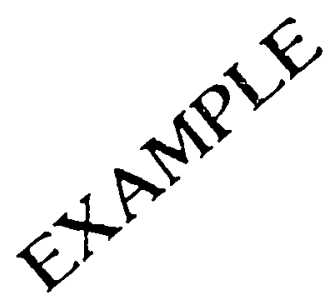

PORTLAND DEVELOPMENT COMMISSION

By

SELF-CONTRACTOR 


\section{CERTIFICATES \\ OF INSPECTION}

Form W-200

\section{City of Portland, Orogon \\ BUREAU OF BUILDINOS \\ HEATING DIVISION \\ CERTIFICATE OF INSPECTION}

Permit No. $-197$

THIS IS TO CERTIFY, That the heating work done under the above

permit at

Owned by

has been inspected by the Heating Division of the Bureau of Buildings and found to comply with the Code of the City of Portland.

FINAL INSPECTION

Heating Contractor

197

Address

By

Heatlng inspector

$\left(\begin{array}{c}\mathbf{w} \cdot \mathbf{2 0} \\ (10-00\end{array}\right)$

\section{CERTIFICATE OF INSPECTION}

BUREAU OF BUILDINGS

Building Division, Portland, Oregon

19

This is to certify that final inspection has been made of the

erected under Permit No.

Located at

Owned by

Erected by

and found to comply with the Building, Housing and Zoning Codes. Plumbing,

Electrical and Heating not included. 
$\operatorname{lomm}_{(2.8 s)} w \cdot 904$

\section{EITY OF MONTLANO, OREOON \\ DUREAL OF GUILDINOA \\ PluMDINO DIVIDION \\ CERTIACATE OF IMSPLCTION}

Fermit No,

THIS IS TO CERTLFY, That the plumbing work done under the above

permit at

Owned by.

has been inspected by the Plumbing Dividion of the Bureau of Bulldings and found to comply with the Ordinances of the City of Portland.

FINAL INBPECTION

19

Contractor

By

MLUMEINE INGSECTDR.

\section{CITY OF PORTLAND. OREGON \\ BUREAU OF BUILDINGS \\ ELECTRICAL DIVISION \\ CERTIFICATE OF INSPECTION}

Permit No. equipment installed work done

, $19 \quad$

THIS IS TO CERTIFY, That the electrical

under the above permit at

S:reet and Number

Owned by

has been inspected by the Electrical

Division of the Bureau of Buildings, and found to comfly with the Ordinances of the City of Portand.

CHIEF ELECTRICAL INSPECTOR

Contractor

By

NOTE-Any aleeration of, or change in, any electrical wiring or apparatus makes

this certificate void. unless a permit is issued for wuch alteration or change. 
THIS WARRANTY CERTIFICATE TO BE RETAINED BY THE CUSTOMER

\section{Carrier \\ Ten-Year Pratection Plan}

WINTER WEATHERMAKERS

One-Year Warranty - We warrant this Corrier product to be free from defects in moteriol and workmonship under normal use and service and we will, within one year from dote of original installation, repoir or reploce without cost to the original customer any part, assembly, or portion thereof which shall be returned to our factory, tronsportotion charges prepoid, and which our inspection shall show to be thus defective.

Nine-Year Replocement Plon-After the expiration of the oneyear warronty and during the second through tenth years afte date of original installotion, for the original purchaser, we further warrant the heat exchanger against defects in material and workmanship and the defective exchanger will be reploced free of charge F.O.B. Corrier foctory if, in the opinion of Corrier, it shows evidence of such defects. This Nine-Year Replacement Plan does not cover lobor or transportation, nor damage due to improper installation, misopplication, improper control or adjustment, firing with incorrect fuel or in excess of roted input copacity, nor damage due to tompering with or alieration of the equipment in any woy.

This Ten-Year Protection Plan does not apply to any parts not supplied or designated by Carrier.. This Ten-Year Protection Plan applies only to Carrier Products installed within the United States of Americo or Cunada.

CARRIER AIR CONDITIONING COMPANY - Syracuse, New York

A DIVISIUN OF CARRIER CORPORATION

Unit Seriol No.

Product Model No Installer

Installation Date

UED-1835 REV. $11 / 67$ 


\section{Ten-Year Protection Plan}

\section{BMPORTANT}

Obligations of Purchaser (not included in this Warranty)

1. Failure to start due to voltoge conditions, blown fuses or other damage due to inadequocy or interruption of electrical service.

2. Filter replacement or cleaning of interchanger.

3. Foilure resulting from overfiring, use of incorrect fuel, and improper burner or control adjustments.

4. Damage caused by accident, misopplication, abuse, alteration, tampering or from servicing by other than on outhorized ogency.

5. Unit must be readily accessible for servieing and/or repuir of all times.
Carrier Corrier products are the result of yeors of research in development laboratories. The most modern precision production methods, together with every precoution through inspection and test, combine to insure long life and economical service. The user of this product should assist in maintaining this moximum of long life and economical service by following the instructions contained in the Instruction Pocket included with the product.

\section{CARRIER AIR CONDITIONING COMPANY A DIVISION OF CARRIER CORPORATION} Syracuse, New York 


\section{HOW TO RESOLVE REHAB WORK DEFECTS}

IMPORTANT: All work performed and materials furnished are warranted for 12 months from the date of Commission certification. If, within that time, you find any defects caused by faulty materials or workmanship that you want corrected by the contractor, you must follow certain procedures.

The contractor must be given written notice with reasonable promptness. This notice may come either from you or from the Commission. If it comes from you, a copy of this notice must be mailed to the Development Commission's Housing Assistance Department. Should the contractor fail to answer or correct the defect(s) within a reasonable time, the Development Commission, at your request, will assist you in the following manner:

1) Staff members of the Housing Assistance Department will investigate the complaint.

2) If the Commission finds the complaint to be invalid, you will be so notified by certified letter. A claim form of the State Building Board will be enclosed in case you wish to pursue the complaint on your own under state law. (Chapter 701 of the Oregon Revised Statutes gives a homeowner the right to file a claim against a contractor for money in the form of a surety bond which the contractor has been required to file with the State Builders Board.)

3) If the Commission finds the complaint to be valid, the Commission will direct the contractor by letter to take necessary corrective action within a specified length of time.

4) If the contractor complies, the Commission will reinspect the work and, if it is satisfactory, you will be expected to sign a written statement withdrawing the complaint.

5) If the contractor fails to respond to the request within the specified length of time, the Commission, upon your request, will prepare a letter for your signature, notifying the contractor a second time that unless the complaint is abated by a specified time, a formal complaint will be filed with the State Building Board for appropriate action.

6) If the contractor fails to respond to the request for correction within the time specified:

a) The Commission will take any necessary action to have the defects corrected, including but not limited to paying the reasonable costs of correcting work or materials determined by the Commission to be defective. By paying such costs, the Commission will assume the role of the homeowner as to any legal claim or claims the homeowner may have against the contractor in regard to such defective work and/or materials.

b) The contractor may be prohibited by the Commission from contracting any other rehabilitation work under any rehabilitation program administered by the Commission. 
NOTES

240

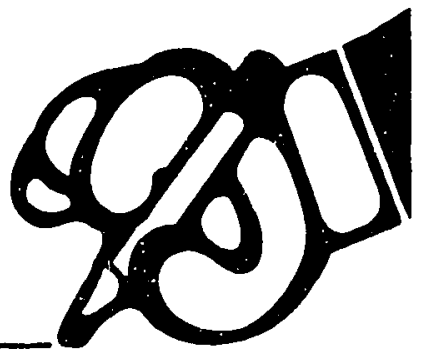


